\title{
Geohydrology of Pahute Mesa-3 Test Well, Nye County, Nevada
}

By KATHRYN C. KILROY and CHARLES S. SAVARD

U.S. GEOLOGICAL SURVEY

Water-Resources Investigations Report 95-4239

Prepared in cooperation with the U.S. DEPARTMENT OF ENERGY

(Interagency Agreement DE-Al08-86-NV10583)

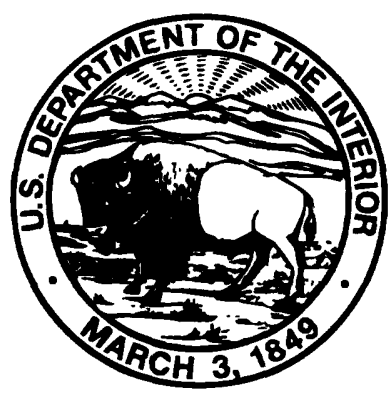

Carson City, Nevada 1996 


\title{
U.S. DEPARTMENT OF THE INTERIOR \\ BRUCE BABBITT, Secretary
}

\author{
U.S. GEOLOGICAL SURVEY \\ GORDON P. EATON, Director
}

Any use of trade names in this publication is for descriptive purposes

only and does not constitute endorsement by the U.S. Government.

For additional information write to:

District Chief

U.S. Geological Survey

333 West Nye Lane, Room 203

Carson City, NV 89706-0866
Copies of this report can be purchased from:

U.S. Geological Survey

Branch of Information Services

Box 25286

Denver, CO 80225-0046 


\section{CONTENTS}

Abstract.

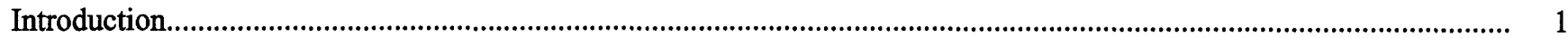

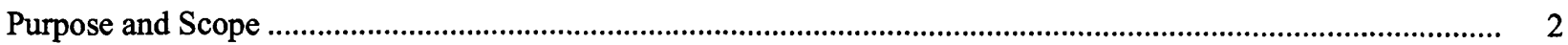

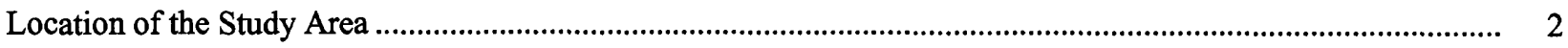

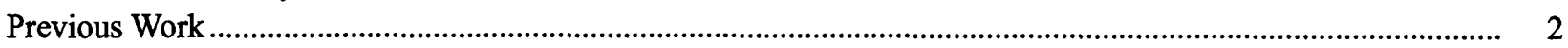

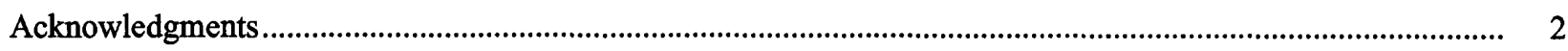

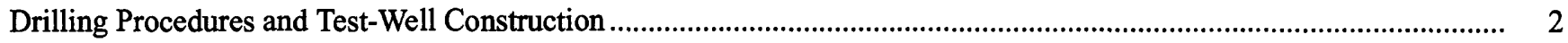

Geology

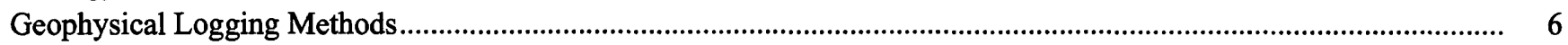

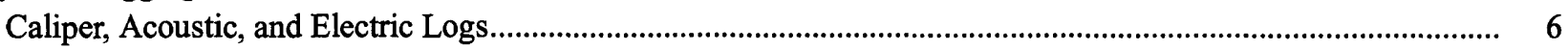

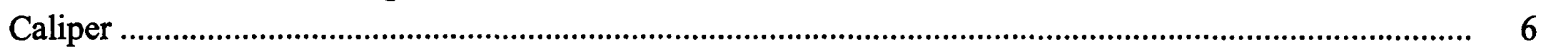

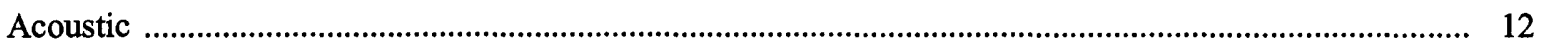

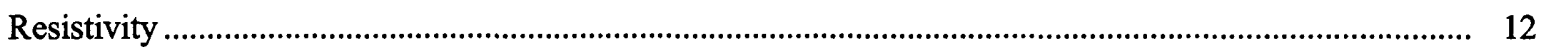

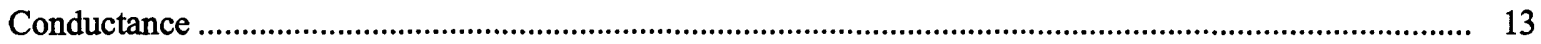

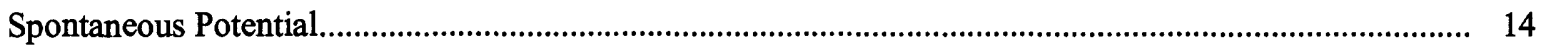

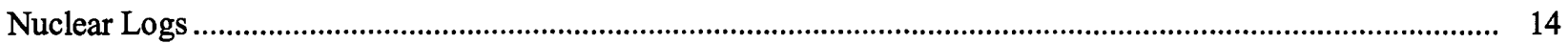

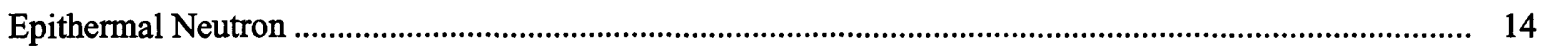

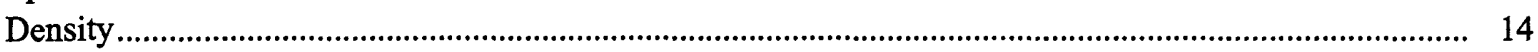

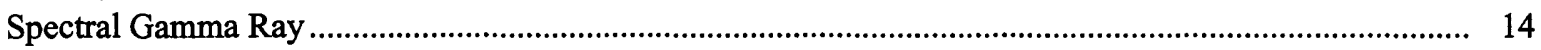

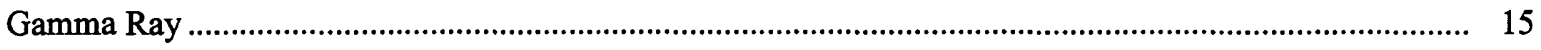

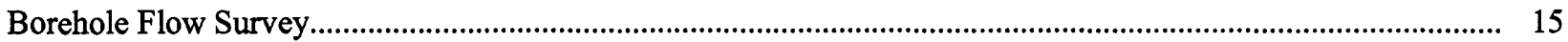

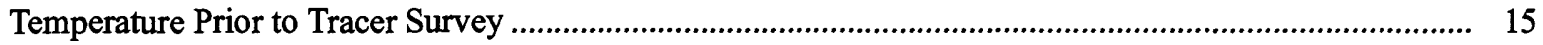

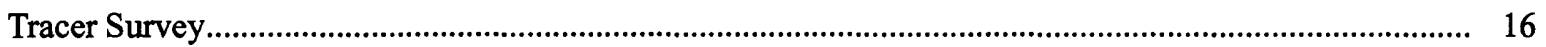

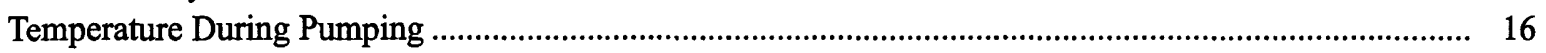

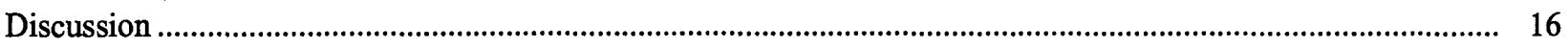

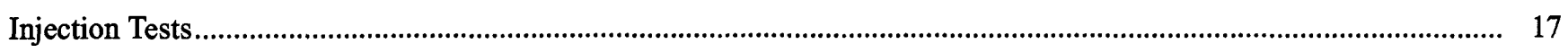

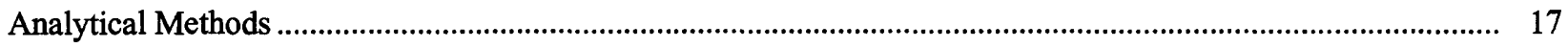

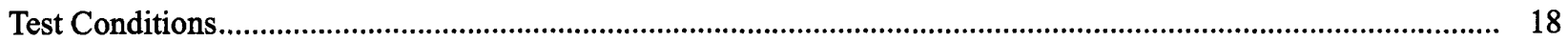

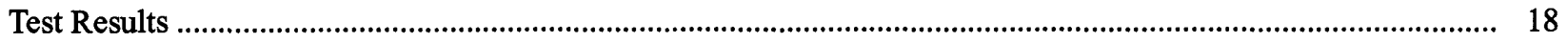

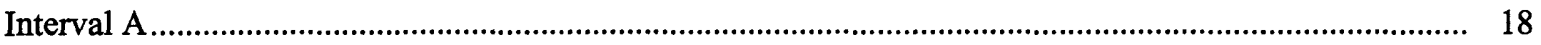

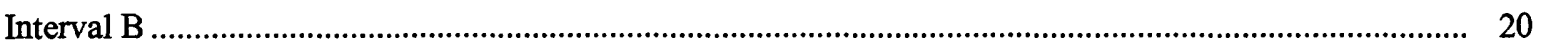

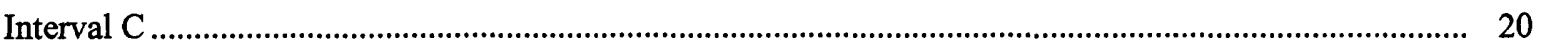

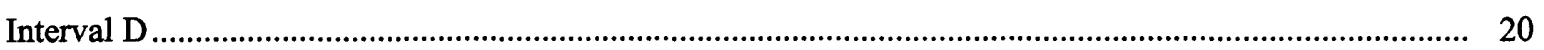

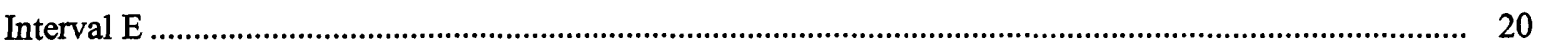

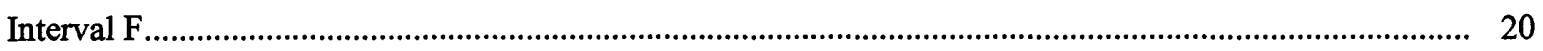

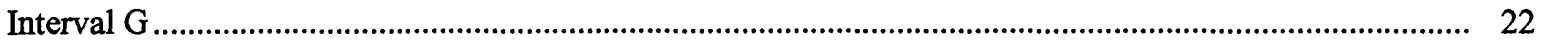

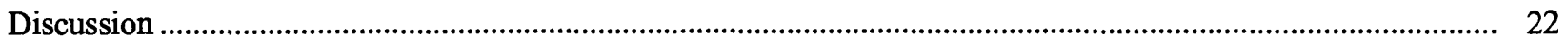

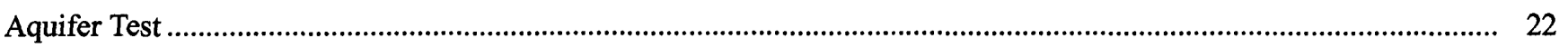

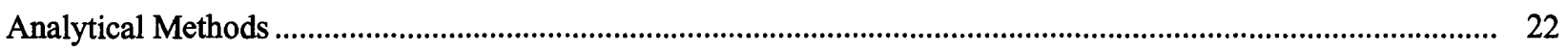

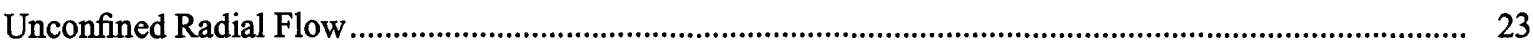

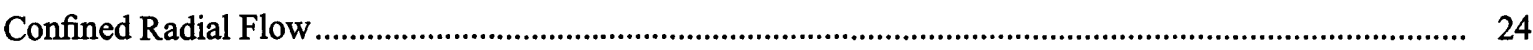

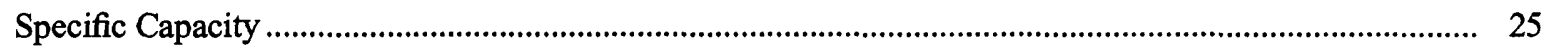

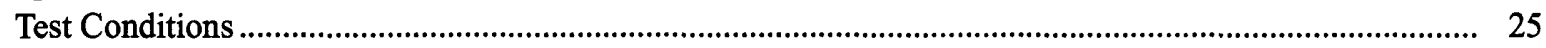

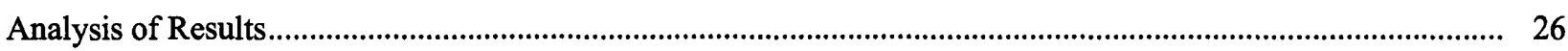

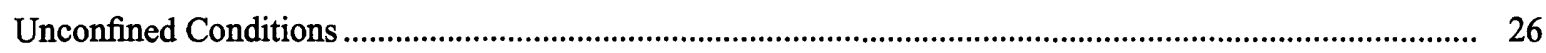

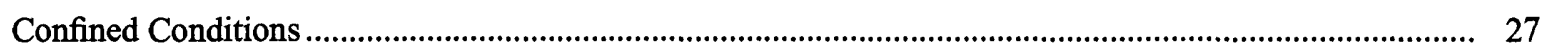

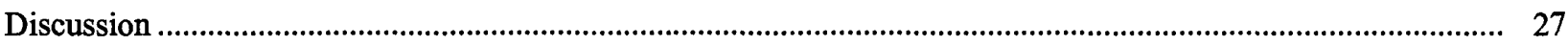


Water Levels

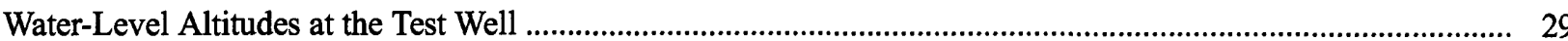

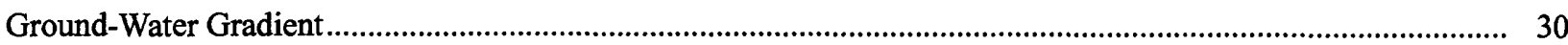

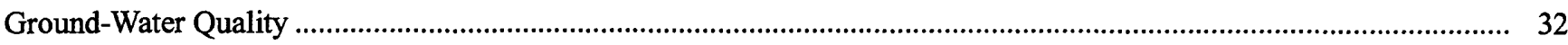

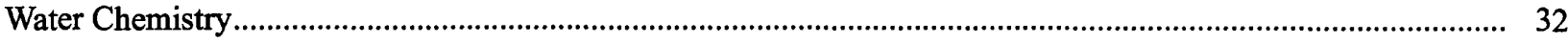

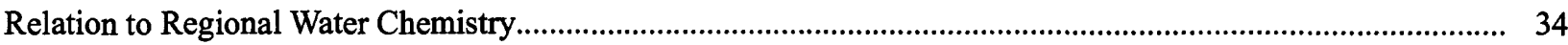

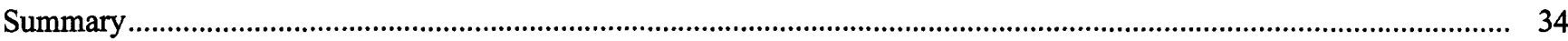

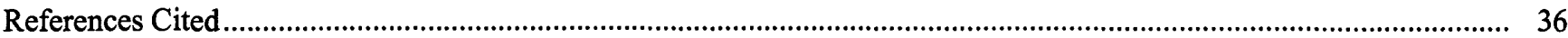

\section{FIGURES}

1. Map showing location of Pahute Mesa-3 test well, Nye County, Nevada ......................................................... 3

2. Diagram showing Pahute Mesa-3 test well hole, casing diameters, and depths, Nye County, Nevada................ 4

3-14. Graphs showing:

3. Caliper, acoustic, geologic, and electric logs from Pahute Mesa-3 test well, Nye County, Nevada............. 9

4. Nuclear logs from Pahute Mesa-3 test well, Nye County, Nevada .............................................................. 10

5. Temperature and tracer-test logs, Pahute Mesa-3 test well, Nye County, Nevada ..................................... 11

6. Intervals isolated by packers during injection testing, Pahute Mesa-3 test well, Nye County, Nevada......... 18

7. Injection-test analyses for depth intervals A, B, and C for Pahute Mesa-3 test well,Nye County, Nevada... 19

8. Injection-test analyses for depth intervals D, F, and G for Pahute Mesa-3 test well, Nye County, Nevada .. 21

9. Analysis of drawdown for an unconfined aquifer under the assumption of delayed yield during pumping and recovery at Pahute Mesa-3 test well, Nye County, Nevada ....................................... 26

10. Analysis of drawdown for an unconfined aquifer under the assumption of delayed yield and correction for well-bore storage during pumping and recovery at Pahute Mesa-3 test well, Nye County, Nevada.

11. Analysis of drawdown for a leaky confined aquifer during pumping and recovery at Pahute Mesa-3 test well, Nye County, Nevada.

12. Analysis of drawdown for a leaky confined aquifer under the assumption of delayed yield and well-bore storage during pumping and recovery at Pahute Mesa-3 test well, Nye County, Nevada ... 30

13. Analysis of drawdown for confined aquifer under the assumption of delayed yield and correction for well-bore storage during pumping and recovery at Pahute Mesa-3 test well, Nye County, Nevada.

14. Water-level altitudes in Pahute Mesa-3 test well, Nye County, Nevada

15. Map showing water-level-altitude contours and ground-water flow direction on Pahute Mesa, Nye County, Nevada.

16. Trilinear plots showing relative cation and anion concentrations for selected Nevada Test Site and vicinity waters, Nye County, Nevada

\section{TABLES}

1. Depth and recovery of sidewall core samples for Pahute Mesa-3 test well, Nye County, Nevada ...................... 6

2. Stratigraphic and lithologic description for Pahute Mesa-3 test well, Nye County, Nevada................................. 7

3. Geophysical logs for Pahute Mesa-3 test well, Nye County, Nevada............................................................ 8

4. Summary of porosity estimates for Pahute Mesa-3 test well, logged September 12, 1988, to September 20, 1988, Nye County, Nevada

5. Summary of injection-test analyses for Pahute Mesa-3 test well, Nye County, Nevada ..................................... 23

6. Summary of aquifer-test analyses for Pahute Mesa-3 test well, Nye County, Nevada....................................... 24

7. Water-quality data for Pahute Mesa-3 test well, Nye County, Nevada .............................................................. 34 
CONVERSION FACTORS, VERTICAL DATUM, AND ABBREVIATIONS

\begin{tabular}{rll}
\hline Multtply & By & To obtain \\
\hline foot $(\mathrm{ft})$ & 0.3048 & meter \\
foot per day $(\mathrm{ft} / \mathrm{d})$ & 0.3048 & meter per day \\
square foot per day $\left(\mathrm{ft}^{2} / \mathrm{d}\right)$ & 0.09290 & meter squared per day \\
cubic foot $\left(\mathrm{ft}^{3}\right)$ & 0.0283 & cubic meter \\
inch $(\mathrm{in})$. & 25.40 & millimeter \\
mile $(\mathrm{mi})$ & 1.609 & kilometer \\
gallon $(\mathrm{gal})$ & 3.785 & liter \\
gallon per minute $(\mathrm{gal} / \mathrm{min})$ & 0.06308 & liter per second \\
part per million $(\mathrm{ppm})$ & 1 & milligram per liter \\
\hline
\end{tabular}

Temperature: Degrees Celsius $\left({ }^{\circ} \mathrm{C}\right)$ can be converted to degrees Fahrenheit $\left({ }^{\circ} \mathrm{F}\right)$ by using the formula ${ }^{\circ} \mathrm{F}=\left[1.8\left({ }^{\circ} \mathrm{C}\right)\right]+32$. Degrees Fahrenheit can be converted to degrees Celsius by using the formula ${ }^{\circ} \mathrm{C}=0.556\left({ }^{\circ} \mathrm{F}-32\right)$.

Sea level: In this report, "sea level" refers to the National Geodetic Vertical Datum of 1929 (NGVD of 1929, formerly called "Sea-Level Datum of 1929"), which is derived from a general adjustment of the first-order leveling networks of the United States and Canada.

Additional abbreviation of units used in this report:

$\mathrm{c} / \mathrm{s}$ (count per second)

$\mathrm{g} / \mathrm{cm}^{3}$ (gram per cubic centimeter)

$\mu \mathrm{g} / \mathrm{L}$ (microgram per liter)

$\mu \mathrm{s} / \mathrm{ft}$ (microsecond per foot)

$\mu \mathrm{S} / \mathrm{cm}$ (microseimen per centimeter at $25^{\circ} \mathrm{C}$ )

$\mathrm{mg} / \mathrm{L}$ (milligrams per liter)

$\mathrm{mho} / \mathrm{m}$ (mho per meter)

mv (millivolt)

$\Omega \mathrm{m}$ (ohm meter) 


\section{Geohydrology of Pahute Mesa-3 Test Well, Nye County, Nevada}

\author{
By Kathryn C. Kilroy and Charles S. Savard
}

\section{ABSTRACT}

The Pahute Mesa-3 test well is on Pahute Mesa about 3 miles west of the Nevada Test Site and 20 miles northeast of Oasis Valley near Beatty, Nevada. The well was drilled for the U.S. Department of Energy Radionuclide Migration Program to monitor conditions near the western edge of the Nevada Test Site. The well was drilled with conventional rotary methods and an air-foam drilling fluid to a depth of 3,019 feet. A 10.75-inch diameter steel casing was installed to a depth of 1,473 feet.

The test well penetrates thick units of nonwelded to partly welded ash-flow and air-fall tuff of Tertiary age with several thin layers of densely welded tuff, rhyolite and basalt flows, and breccia. Geophysical logs indicate that fractures are significant in the Tiva Canyon Tuff of the Paintbrush Group and this was confirmed by high flow in this unit during a borehole-flow survey. The geophysical logs also show that the effective porosity in tuffaceous units ranges from 19 to 38 percent and averages 30 percent, and the total porosity ranges from 33 to 55 percent and averages 42 percent. The measured temperature gradient of 1.00 degree Celsius per 100 feet is steep, but is similar to that of other nearby wells, one of which penetrates a buried granite intrusion.

Injection tests for six intervals of the well yielded transmissivities that ranged from $3.1 \times 10^{-3}$ to 25 feet squared per day and hydraulic conductivities that ranged from $6 \times 10^{-5}$ to 0.12 foot per day. The sum of the transmissivities is 28 feet squared per day and the geometric mean of hydraulic conductivity is $1.7 \times 10^{-3}$ foot per day. Estimates of storage coefficient range from $2.1 \times 10^{-5}$ to $3.8 \times 10^{-3}$, indicating that the aquifer responded to the injection tests in a confined manner.
An aquifer test produced a drawdown of 78 feet during 31 hours of testing at 169 gallons per minute. Assuming that the aquifer is confined, estimates of transmissivity range from 360 to 840 feet squared per day and hydraulic conductivity ranges from 0.32 to 0.74 foot squared per day. The combined results of geophysical logging, injection tests, and aquifer tests indicate that most ground-water flow is in fractured intervals.

The water-level altitude in the test well fluctuated 6 feet, from 4,362 to 4,368 feet above sea level, during the 1988-90 study period.

The test well has a sodium-mixed-anion water. Sodium concentration is high compared to other water in the Pahute Mesa and Yucca Mountain area, but is similar to water in Oasis Valley. The water chemistry suggests that ground water in the vicinity of Pahute Mesa-3 test well may flow toward the south.

\section{INTRODUCTION}

The Hydrology-Radionuclide Migration Program (HRMP) is managed by the U.S. Department of Energy (USDOE) to address concerns about possible groundwater contamination from underground nuclear testing at the Nevada Test Site (NTS). Lawrence Livermore National Laboratory, Los Alamos National Laboratory, Desert Research Institute (DRI), and the U.S. Geological Survey work in cooperation with USDOE to investigate specific concerns relating to possible contamination. The overall objective of the program is to understand radionuclide migration and hydrologic processes in the NTS area.

The direction and rate of ground-water flow in and outside NTS are two hydrologic processes investigated by this program. The HRMP has initiated a drilling program to collect the data necessary to make interpretations of ground-water gradient, flow 
direction, and rate. The work described in this report was done in cooperation with USDOE under interagency agreement DE-AI08-86-NV10583.

\section{Purpose and Scope}

The purpose of this report is to (1) present data collected from the drilling, testing, and monitoring of the Pahute Mesa-3 test well and (2) provide an initial geohydrologic interpretation of the data. The report includes discussions of the drilling, construction, and testing of the well. It also includes descriptions of geology, geohydrology, hydraulic properties, water level, and water quality for the formations penetrated by the test well. Data collected during drilling, borehole geophysical surveys, injection tests, an aquifer test, and geochemical sampling are presented and interpreted. Water levels are presented for the 2-year period following well completion (September 1988-January 1991).

\section{Location of the Study Area}

Pahute Mesa-3 test well, referred to as PM-3 in this report, is on the western slope of Pahute Mesa at an altitude of 5,823 $\mathrm{ft}$ above sea level, between the NTS and Oasis Valley about 25 mi northeast of Beatty, Nev. (fig. 1). Pahute Mesa is a volcanic plateau composed of ash-flow and air-fall tuffs, rhyolitic to basaltic flows, volcanic sediments, and flow domes erupted from numerous caldera complexes. The site is $3 \mathrm{mi}$ west of the NTS boundary, $20 \mathrm{mi}$ northeast of Oasis Valley, $30 \mathrm{mi}$ north of Yucca Mountain, and $150 \mathrm{mi}$ northwest of Las Vegas. The test well is at Nevada coordinates N906021 E530998, which correspond to latitude $37^{\circ} 14^{\prime} 21^{\prime \prime}$ and longitude $116^{\circ} 33^{\prime} 37^{\prime \prime}$. It is in the Oasis Valley hydrographic area of Rush (1968). It is in a flyover area for the U.S. Air Force Bombing and Gunnery Range.

\section{Previous Work}

Malmberg and Eakin (1962) described the flow system, and Malmberg and Eakin (1964) and White (1979) discussed the geochemistry of ground water in Oasis Valley. Blankennagel and Weir (1973) described the regional hydrogeologic and tertiary stratigraphic framework of the eastern part of Pahute Mesa. Winograd and Thordarson (1975) extended this framework throughout the NTS area. Sawyer and others (1994) revised the stratigraphic framework on the basis of
Argon-40/Argon-39 geochronology. Waddell and others (1984) mapped the ground-water altitudes of a large part of southwestern Nevada, and Claassen (1985) discussed part of the Pahute Mesa ground-water flow system in an evaluation of recharge to Amargosa Desert.

The geology of the area around PM-3 was first mapped in detail by O'Connor and others (1966). Their work was later incorporated into geologic maps that included the Pahute Mesa area by Orkild and others (1969) and the Timber Mountain area studied by Byers and others (1976a) who discussed the volcanic calderas and lithologic suites common to the Pahute Mesa.

\section{Acknowledgments}

Personnel of the U.S. Geological Survey thank all individuals and agencies involved in collecting and analyzing the data described in this report. This report was funded by the U.S. Department of Energy (Interagency Agreement DE-AI08-86-NV10583). Reynolds Electrical and Engineering Company drilled the test well and provided support during the hydraulic testing operations. Fenix and Scisson, Inc., provided support for drilling, engineering, and geologic analysis. Atlas Wireline, Inc., did the geophysical logging and analyzed some of the logs. Baker, Inc., supplied packer and injection equipment and made injection tests. Desert Research Institute collected and analyzed water samples. The U.S. Air Force granted access to the test well on their bombing and gunnery range.

\section{DRILLING PROCEDURES AND TEST- WELL CONSTRUCTION}

PM-3 was drilled to a depth of 3,019 $\mathrm{ft}$ below land surface in three stages (fig. 2). The objective of the first phase of drilling was to penetrate unconsolidated materials and regolith and set the surface casing. A 24-in. diameter hole was drilled in the first stage from 0 to $124 \mathrm{ft}$ on September 1, 1988. A 16-in. outside-diameter surface casing was set in the hole from 0 to $93 \mathrm{ft}$ and cemented from $93 \mathrm{ft}$ to the surface.

The objective of the second phase of drilling was to reach the water table, estimated to be between 1,200 and $1,800 \mathrm{ft}$ below the land surface. A 14.75-in. diameter hole was drilled September 2-9, from 124 to $1,647 \mathrm{ft}$ deep. Drilling fluid became thinner at approximately $1,647 \mathrm{ft}$, indicating that the water table had been reached. The water table was later measured at $1,456 \mathrm{ft}$ during the first round of geophysical logging. 


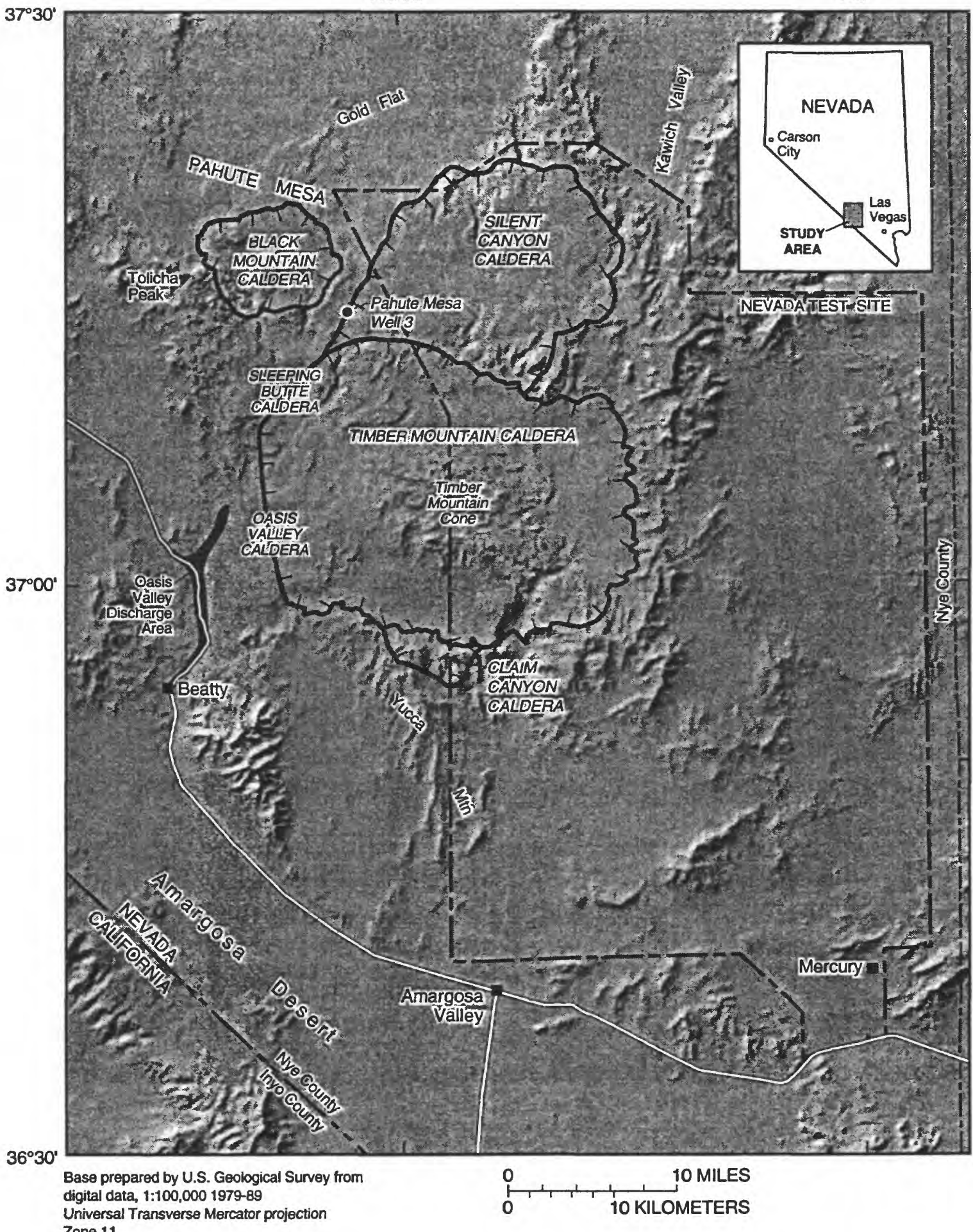

Zone 11

Figure 1. Location of Pahute Mesa-3 test well, Nye County, Nevada. 


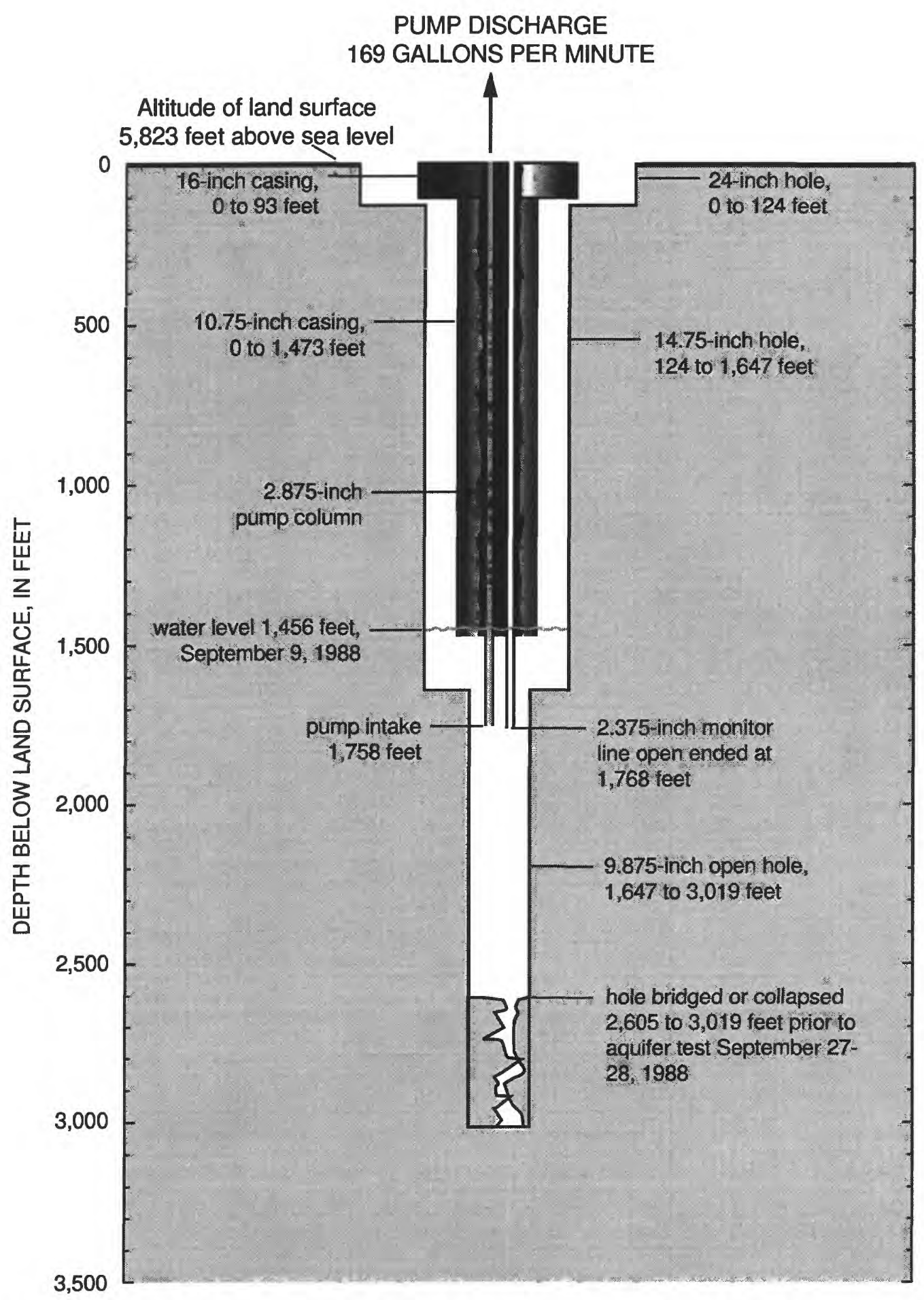

Figure 2. Pahute Mesa-3 test well hole, casing diameters, and depths, Nye County, Nevada. 
A 10.75-in. outside diameter casing was set in the hole from 0 to $1,473 \mathrm{ft}$ on September 14. The bottom $150 \mathrm{ft}$ of the 10.75-in casing is stainless steel to meet standards for water-quality sampling. The bottom of the hole, between 1,473 and $1,647 \mathrm{ft}$, was filled with sand before the 10.75-in. casing was cemented in the hole. More than $150 \mathrm{ft}^{3}$ of neat cement was used.

The objective of the third stage of drilling was to develop the productive segment of the test well. The sand was flushed from the bottom of the well at the beginning of drilling the third segment. A 9.875-in. diameter hole was drilled from 1,647 to $3,019 \mathrm{ft}$ on September 15-19. The bottom $1,546 \mathrm{ft}$ of the test well, from 1,473 to $3,019 \mathrm{ft}$, was left uncased to allow hydraulic testing of the formations in the saturated zone.

Borehole geophysical surveys were done after the second and third phases of drilling in mid-September, and again during the aquifer test on September 27-28. Injection tests were made after well completion, from September 23-26.

The air-foam drilling fluid was a mixture of air, water, soap, and minor amounts of bentonite and polymer. The fluid was circulated down the drill stem with compressed air, then through the drill bit and up the well annulus. The drilling fluid was not recirculated, but was disposed in a sump at the test-well location. A lithium bromide tracer was added to maintain the drilling fluid at a concentration of $20 \mathrm{mg} / \mathrm{L}$. The purpose of the tracer is to differentiate water introduced during drilling from natural formation water during waterquality sampling.

Drill-bit cuttings and sidewall cores were collected to aid in definition of lithology. A bucket at the end of the "blooie line," the pipe carrying the drilling returns from the wellhead to the sump, collected part of the returns. Drill-bit cuttings were collected every $10 \mathrm{ft}$ during the drilling operation. The cutting samples and sidewall cores were washed, examined, and stored at the U.S. Geological Survey Core Library in Mercury, Nev. Cutting samples were not collected from the following five intervals: from 60 to $70 \mathrm{ft}$; from 660 to $670 \mathrm{ft}$; from 1,230 to $1,240 \mathrm{ft}$; from 1,240 to $1,250 \mathrm{ft}$; and from 1,290 to $1,300 \mathrm{ft}$.

Sidewall core samples were collected with a percussion gun during the geophysical-logging operation. Additional sidewall cores were collected from 1,465 to $469 \mathrm{ft}$ in an attempt to sample an anomalous gamma source identified by the gamma log. Sidewall core recovery was approximately 50 percent. The depth and recovery length of sidewall core samples are listed in table 1.

A 9.875-in. drill bit was used in the test well on October 21, 1988, to remove debris that had fallen into the hole during the previous month. A pump was set at $1,655 \mathrm{ft}$ on October 27 and pumped at $180 \mathrm{gal} / \mathrm{min}$ for 24 hours to remove introduced water from the test well and formation. A locking wellhead cover was installed on October 28.

\section{GEOLOGY}

Pahute Mesa is a rolling plateau composed primarily of silicic volcanic rocks of Tertiary age. The volcanic rocks were erupted along an east trending belt of caldera complexes that spans the State between latitudes 37 and 38 degrees north. Volcanic activity occurred primarily between approximately 17 and 6 million years overlapping the early phase of Basin and Range normal faulting that began approximately 11 million years; therefore some of the volcanic rocks are highly fractured. Four calderas are mapped in the vicinity of Pahute Mesa. These are the Black Mountain, Claim Canyon, Silent Canyon, and Timber Mountain calderas (fig. 1). Deposits associated with the caldera complexes include: glassy and crystalline flows, hypabyssal intrusions, air-fall, ash-flow, lapilli, and reworked tuffs, and tectonic, eruptive, and flow breccias. Unit thickness and particle size decrease with distance from the caldera boundaries.

PM-3 is located between the Black Mountain, Silent Canyon, and Timber Mountain calderas (fig. 1). The Silent Canyon caldera boundary was mapped based on gravity studies by Healey (1968) and Healey and others (1987). The boundary of the Timber Mountain caldera was identified by topography, Bouguer gravity data, and aeromagnetic data (Byers and others, 1976b). S.L. Drellack (Fenix and Scisson, Inc., written commun., 1988) determined that the test well is outside either caldera boundary on the basis of stratigraphy, lithology, and the thickness of the units penetrated. He also observed that the two breccia deposits, from 1,810 to $1,835 \mathrm{ft}$ and from 2,280 to $2,295 \mathrm{ft}$ in depth, indicate that the test well is on a structural bench related to the Silent Canyon caldera.

A lithologic description of well PM-3 is shown in table 2 . Approximately 85 percent of the units penetrated by the well are tuffs, 5 percent are rhyolite flows, 5 percent are basalt flows, and 5 percent are breccias. 
Table 1. Depth and recovery of sidewall core samples for Pahute Mesa-3 test well, Nye County, Nevada

\begin{tabular}{|c|c|c|c|}
\hline $\begin{array}{l}\text { Depth } \\
\text { (feet) }\end{array}$ & $\begin{array}{l}\text { Recovery } \\
\text { (inches) }\end{array}$ & $\begin{array}{l}\text { Depth } \\
\text { (feet) }\end{array}$ & $\begin{array}{c}\text { Recovery } \\
\text { (inches) }\end{array}$ \\
\hline \multicolumn{4}{|c|}{ September 13, 1988} \\
\hline $\begin{array}{l}470^{\mathrm{b}} \\
480^{\mathrm{b}} \\
490^{\mathrm{b}} \\
500^{\mathrm{b}} \\
510^{\mathrm{b}}\end{array}$ & $\begin{array}{l}2.0 \\
1.5 \\
2.0 \\
2.0 \\
0.5\end{array}$ & $\begin{array}{l}1,464.3^{\mathrm{a}} \\
1,464.7^{\mathrm{a}} \\
1,465.0^{\mathrm{a}} \\
1,465.3^{\mathrm{a}} \\
1,465.5^{\mathrm{a}}\end{array}$ & $\begin{array}{l}1.5 \\
1.5 \\
1.5 \\
0.7 \\
1.2\end{array}$ \\
\hline $\begin{array}{l}650^{\mathrm{a}} \\
670^{\mathrm{a}} \\
680^{\mathrm{a}} \\
690^{\mathrm{a}} \\
735^{\mathrm{a}}\end{array}$ & $\begin{array}{c}1.2 \\
2.0 \\
2.0 \\
2.0 \\
\text { Trace }\end{array}$ & $\begin{array}{l}1,466.0^{\mathrm{a}} \\
1,466.3^{\mathrm{a}} \\
1,466.7^{\mathrm{a}} \\
1,467.0^{\mathrm{a}} \\
1,467.3^{\mathrm{a}}\end{array}$ & $\begin{array}{l}1.2 \\
0.5 \\
1.2 \\
0.7 \\
1.0\end{array}$ \\
\hline $\begin{array}{l}740^{\mathrm{a}} \\
750^{\mathrm{a}} \\
825^{\mathrm{a}} \\
840^{\mathrm{a}} \\
845^{\mathrm{a}}\end{array}$ & $\begin{array}{l}0.5 \\
1.0 \\
2.0 \\
2.0 \\
1.2\end{array}$ & $\begin{array}{l}1,468.0^{\mathrm{a}} \\
1,468.7^{\mathrm{a}} \\
1,469.0^{\mathrm{a}} \\
1,469.3^{\mathrm{a}} \\
1,470^{\mathrm{a}}\end{array}$ & $\begin{array}{c}0.2 \\
1.2 \\
.05 \\
\text { Trace } \\
1.5\end{array}$ \\
\hline $\begin{array}{r}880^{\mathrm{a}} \\
1,000^{\mathrm{a}} \\
1,025^{\mathrm{a}} \\
1,160^{\mathrm{a}} \\
1,230^{\mathrm{a}}\end{array}$ & $\begin{array}{l}1.5 \\
1.5 \\
2.0 \\
2.0 \\
2.0\end{array}$ & $\begin{array}{l}1,490^{\mathrm{a}} \\
1,510^{\mathrm{a}} \\
1,530^{\mathrm{a}} \\
1,580^{\mathrm{a}} \\
1,600^{\mathrm{a}}\end{array}$ & $\begin{array}{l}1.5 \\
1.2 \\
1.5 \\
1.2 \\
1.0\end{array}$ \\
\hline $\begin{array}{l}1,240^{\mathrm{a}} \\
1,245^{\mathrm{a}} \\
1,395^{\mathrm{a}} \\
1,440^{\mathrm{a}} \\
1,460^{\mathrm{a}} \\
\end{array}$ & $\begin{array}{l}1.0 \\
2.0 \\
2.0 \\
0.2 \\
1.5\end{array}$ & $1,620^{\mathrm{a}}$ & 1.2 \\
\hline \multicolumn{4}{|c|}{ September 23, 1988} \\
\hline $\begin{array}{l}1,625^{\mathrm{a}} \\
1,635^{\mathrm{a}} \\
1,645^{\mathrm{a}} \\
1,655^{\mathrm{a}} \\
1,665^{\mathrm{a}}\end{array}$ & $\begin{array}{l}1.5 \\
1.5 \\
1.5 \\
1.5 \\
1.5\end{array}$ & $\begin{array}{l}2,160^{\mathrm{c}} \\
2,200^{\mathrm{c}} \\
2,230^{\mathrm{c}} \\
2,280^{\mathrm{c}} \\
2,310^{\mathrm{c}}\end{array}$ & $\begin{array}{l}1.0 \\
2.0 \\
1.0 \\
1.0 \\
2.0\end{array}$ \\
\hline $\begin{array}{l}1,670^{\mathrm{a}} \\
1,675^{\mathrm{a}} \\
1,685^{\mathrm{a}} \\
1,700^{\mathrm{a}} \\
1,700^{\mathrm{a}}\end{array}$ & $\begin{array}{l}1.5 \\
1.5 \\
0.5 \\
1.5 \\
1.5\end{array}$ & $\begin{array}{l}2,330^{\mathrm{c}} \\
2,370^{\mathrm{c}} \\
2,400^{\mathrm{c}} \\
2,420^{\mathrm{c}} \\
2,450^{\mathrm{c}}\end{array}$ & $\begin{array}{l}1.0 \\
2.0 \\
1.5 \\
1.5 \\
2.0\end{array}$ \\
\hline $\begin{array}{l}1,720^{\mathrm{a}} \\
1,750^{\mathrm{a}} \\
1,815^{\mathrm{a}} \\
1,845^{\mathrm{a}} \\
1,920^{\mathrm{c}}\end{array}$ & $\begin{array}{l}1.5 \\
1.0 \\
0.5 \\
1.0 \\
1.0\end{array}$ & $\begin{array}{l}2,505^{\mathrm{c}} \\
2,550^{\mathrm{c}} \\
2,600^{\mathrm{c}} \\
2,650^{\mathrm{c}} \\
2,670^{\mathrm{c}}\end{array}$ & $\begin{array}{l}1.5 \\
2.0 \\
2.0 \\
2.0 \\
2.0\end{array}$ \\
\hline $\begin{array}{l}1,945^{\mathrm{c}} \\
2,015^{\mathrm{c}} \\
2,080^{\mathrm{c}} \\
2,110^{\mathrm{c}} \\
2,140^{\mathrm{c}}\end{array}$ & $\begin{array}{l}1.0 \\
1.0 \\
2.0 \\
1.5 \\
1.0\end{array}$ & $\begin{array}{l}2,700^{\mathrm{c}} \\
2,730^{\mathrm{c}} \\
2,770^{\mathrm{d}} \\
2,800^{\mathrm{d}} \\
2,825^{\mathrm{d}}\end{array}$ & $\begin{array}{l}1.0 \\
1.5 \\
1.5 \\
1.5 \\
2.0\end{array}$ \\
\hline
\end{tabular}

${ }^{a}$ Timber Mountain Group

${ }^{b}$ Fortymile Canyon assemblage
Although devitrified units occur throughout the stratigraphic column, argillic alteration is primarily below the water table; and zeolitic alteration is found below, and up to $500 \mathrm{ft}$ above, the water table.

\section{GEOPHYSICAL LOGGING METHODS}

Geophysical logs were used to help define the lithology, stratigraphy, and hydrogeology of units penetrated by PM-3. Three rounds of geophysical logging were completed. The first round was recorded September 9-14, 1988, after the second phase of drilling but prior to casing, when the well was $1,647 \mathrm{ft}$ deep (table 3). It included caliper, epithermal neutron, fluid-density, gamma-gamma, gamma ray, electric, magnetometer, and temperature logs. Fluid-density logs were recorded only to determine depth to water, which varied between 1,455 and 1,457 ft. The second round of measurements was recorded September 19-23, 1988, when the test well was drilled to its total depth of 3,019 ft. This included all the previously mentioned geophysical logs except the gamma ray and magnetometer survey. In addition, it included a borehole-compensated acoustic log and a gyroscope survey. The third round of measurements was recorded on September 27, 1988, during the aquifer test. It included temperature and tracer surveys. The geophysical logs are shown in figures 3,4 , and 5 .

The gyroscopic directional survey showed the test well to be nearly vertical, requiring a $-0.1 \mathrm{ft}$ correction to measured depths below $2,900 \mathrm{ft}$. At $2,900 \mathrm{ft}$, the hole is $6.5 \mathrm{ft}$ north and $1.0 \mathrm{ft}$ east of the surface coordinates of the test well. The directional survey log is not shown.

\section{Caliper, Acoustic, and Electric Logs}

The caliper, acoustic, and electric logs are shown in figure 3.

\section{Caliper}

Faults, friable units, and true borehole diameter can be identified from the caliper log (fig. 3). The caliper log also is used extensively in interpreting electric and nuclear logs because these methods are sensitive to variations in borehole diameter and a correction commonly is needed. Several caliper logs were completed at PM-3, including a three-pronged log, but only one is shown here because deviation from roundness was slight. The caliper had a maximum span of $31.7 \mathrm{in}$. and 
Table 2. Stratigraphic and lithologic description of Pahute Mesa-3 test well, Nye County, Nevada

(Geology by S.L. Drellack, Jr., Fenix and Scisson Engineering, written commun., 1988. Descriptions of color, lithic inclusions, and phenocrysts are omitted.)

\begin{tabular}{|c|c|c|c|}
\hline $\begin{array}{l}\text { Stratigraphic } \\
\text { unit }\end{array}$ & Member & $\begin{array}{l}\text { Bottom of } \\
\text { depth Interval } \\
\text { (feet below } \\
\text { land surface) }\end{array}$ & Lithology \\
\hline $\begin{array}{l}\text { Thirsty Canyon Group } \\
\text { (Pliocene) }\end{array}$ & $\begin{array}{l}\text { Trail Ridge Tuff } \\
\text { do. } \\
\text { Pahute Mesa Tuff } \\
\text { do. }\end{array}$ & $\begin{array}{r}80 \\
120 \\
150 \\
175\end{array}$ & $\begin{array}{l}\text { Tuff-ash-flow, densely welded, devitrified } \\
\text { Tuff_bedded, vitric, friable } \\
\text { Tuff_-ash-flow, densely welded, devitrified } \\
\text { Tuff-nonwelded or bedded, friable, vitric }\end{array}$ \\
\hline \multirow[t]{3}{*}{$\begin{array}{l}\text { Timber Mountain Group } \\
\text { (Pliocene) }\end{array}$} & $\begin{array}{l}\text { Ammonia Tanks Tuff } \\
\text { do. } \\
\text { do. } \\
\text { Rainer Mesa Tuff }\end{array}$ & $\begin{array}{l}530 \\
595 \\
620 \\
820\end{array}$ & $\begin{array}{l}\text { Tuff_-ash-flow, nonwelded, friable, vitric } \\
\text { Tuff_-ash-flow, partly welded, vitric } \\
\text { Tuff_-bedded, vitric and friable, silicified } \\
\text { Tuff_-ash-flow, partly to moderately welded, devitrified }\end{array}$ \\
\hline & $\begin{array}{l}\text { do. } \\
\text { do. } \\
\text { Rhyolite of the Loop } \\
\text { do. }\end{array}$ & $\begin{array}{l}1,020 \\
1,235 \\
1,308 \\
1,470\end{array}$ & $\begin{array}{l}\text { Tuff-ash-flow(?), nonwelded, devitrified to weakly zeolitized } \\
\text { Tuff-ash-flow, nonwelded, zeolitized } \\
\text { Tuff-nonwelded or bedded, zeolitized } \\
\text { Tuff-ash-flow, nonwelded, zeolitized }\end{array}$ \\
\hline & $\begin{array}{l}\text { do. } \\
\text { do. } \\
\text { Basalt of well U-19ac } \\
\text { Breccia }\end{array}$ & $\begin{array}{l}1,492 \\
1,750 \\
1,810 \\
1,835\end{array}$ & $\begin{array}{l}\text { Tuff-reworked (?), zeolitized, possibly argillized } \\
\text { Tuff-ash-flow, nonwelded, zeolitized } \\
\text { Basalt lava, zeolitized, argillized, weakly calcareous } \\
\text { Breccia, densely welded tuff fragments in tuffaceous matrix }\end{array}$ \\
\hline $\begin{array}{l}\text { Paintbrush Group } \\
\text { (Miocene) }\end{array}$ & $\begin{array}{l}\text { Tiva Canyon Tuff } \\
\text { do. } \\
\text { do. } \\
\text { do. } \\
\text { Hornblende rhyolite }\end{array}$ & $\begin{array}{l}1,885 \\
1,920 \\
2,100 \\
2,140 \\
2,280\end{array}$ & $\begin{array}{l}\text { Tuff-reworked, zeolitized } \\
\text { Tuff-ash-flow, nonwelded to partly welded, devitrified } \\
\text { Tuff-ash-flow, moderately welded } \\
\text { Tuff-ash-flow, nonwelded to partly welded } \\
\text { Tuff-bedded, zeolitized }\end{array}$ \\
\hline $\begin{array}{l}\text { Calico Hills Formation } \\
\text { (Miocene) }\end{array}$ & $\begin{array}{l}\text { "lower unit" } \\
\text { do. } \\
\text { Basalt of well UE-19e }\end{array}$ & $\begin{array}{l}2,770 \\
2,810 \\
2,870\end{array}$ & $\begin{array}{l}\text { Tuff-bedded, zeolitized } \\
\text { Tuff-air-fall, zeolitized } \\
\text { Basalt, devitrified }\end{array}$ \\
\hline $\begin{array}{l}\text { Wahmonie Formation } \\
\text { (Miocene) }\end{array}$ & $\begin{array}{l}\text { Bedded tuffs } \\
\text { do. }\end{array}$ & $\begin{array}{l}2,890 \\
2,910\end{array}$ & $\begin{array}{l}\text { Tuff-bedded, zeolitized to argillized } \\
\text { Tuff-ash-fall, very fine grained ash, zeolitized, argillized }\end{array}$ \\
\hline Crater Flat Group (Miocene) & Bullfrog Tuff & 2,950 & Tuff_-ash-flow, zeolitized to argillized, partly welded \\
\hline $\begin{array}{l}\text { Belted Range Group } \\
\text { (Miocene) }\end{array}$ & Grouse Canyon Tuff & 2,990 & Tuff_-ash-flow, densely welded, flow banded, devitrified \\
\hline Pre-Grouse Canyon (Miocene) & & 3,000 & Tuff_bedded, some reworked tuff, zeolitized, argillized \\
\hline Tuffs (Miocene) & & 3,019 & Tuff-nonwelded or bedded, argillized, zeolitized \\
\hline
\end{tabular}


Table 3. Geophysical logs for Pahute Mesa-3 test well, Nye County, Nevada

[Abbreviations: API, American Petroleum Institute; c/s, counts per second; in., inches; ${ }^{\circ} \mathrm{F}$, degrees Fahrenheit; ft, foot; $\mathrm{g} / \mathrm{cm}^{3}, \mathrm{grams}$ per cubic centimeter; $\mu \mathrm{s} / \mathrm{ft}$, microseconds per foot; $\Omega \mathrm{m}$, ohm meter; ppm, parts per million]

\begin{tabular}{|c|c|c|c|c|}
\hline \multirow{2}{*}{$\begin{array}{l}\text { Geophysical log } \\
\text { and adjustment }\end{array}$} & \multirow{2}{*}{$\begin{array}{l}\text { Run } \\
\text { No. }\end{array}$} & \multirow[b]{2}{*}{ Date } & \multirow{2}{*}{$\begin{array}{l}\text { Interval } \\
\text { surveyed } \\
\text { (feet below } \\
\text { land surface) }\end{array}$} & Calibration \\
\hline & & & & $\begin{array}{l}\text { Measurement } \\
\text { and unit }\end{array}$ \\
\hline Acoustic (borehole compensated) & 1 & $09-20-88$ & $1,480-2,882$ & $\begin{array}{l}57 \mu \mathrm{s} / \mathrm{ft}^{\mathrm{a}} \\
57 \mu \mathrm{s} / \mathrm{ft}^{\mathrm{b}}\end{array}$ \\
\hline \multirow[t]{3}{*}{ Caliper } & 1 & $09-12-88$ & $40-1,624$ & \multirow{3}{*}{$\begin{array}{l}12,20,31.7 \text { in. }^{a} \\
12,20 \text { in. }^{\mathrm{b}} \\
8,16,31.4 \text { in. }^{\mathrm{a}} \\
8,16 \text { in. }^{\text {b }}\end{array}$} \\
\hline & 2 & $09-20-88$ & $1,405-2,897$ & \\
\hline & 3 & $09-23-88$ & $1,406-2,810$ & \\
\hline \multirow[t]{2}{*}{$\begin{array}{l}\text { Epithermal neutron } \\
\text { (decentralized long spacing) }\end{array}$} & 1 & $09-13-88$ & $58-1,629$ & \multirow{2}{*}{$\begin{array}{l}567,1237,3199 \text { API units }^{\mathrm{a}} \\
567,1237,3199 \text { API units }^{\mathrm{b}} \\
567,1237,3199 \text { API units } \\
\text { 567, 1237, } 3199 \text { API units }\end{array}$} \\
\hline & 2 & $09-21-88$ & $1,419-2,812$ & \\
\hline \multirow[t]{5}{*}{ Fluid density } & 1 & $09-12-88$ & $1,399-1,476$ & \multirow[t]{3}{*}{$\begin{array}{l}100,300 \mathrm{c} / \mathrm{s}^{\mathrm{a}} \\
90,290 \mathrm{c} / \mathrm{s}^{\mathrm{b}}\end{array}$} \\
\hline & 2 & $09-13-88$ & $1,352-1,410$ & \\
\hline & $\begin{array}{l}3 \\
4\end{array}$ & $\begin{array}{l}09-14-88 \\
09-14-88\end{array}$ & $\begin{array}{l}1,352-1,408 \\
1,352-1,476\end{array}$ & \\
\hline & 5 & $09-21-88$ & $1,395-1,477$ & \multirow[t]{2}{*}{$\begin{array}{l}75,262 \mathrm{c} / \mathrm{s}^{\mathrm{a}} \\
70,260 \mathrm{c} / \mathrm{s}^{\mathrm{b}}\end{array}$} \\
\hline & $\begin{array}{l}6 \\
7\end{array}$ & $\begin{array}{l}09-23-88 \\
10-10-88\end{array}$ & $\begin{array}{l}1,392-1,480 \\
1,432-1,272\end{array}$ & \\
\hline \multirow[t]{2}{*}{$\begin{array}{l}\text { Gamma-gamma } \\
\text { (borehole-compensated density log) }\end{array}$} & 1 & $09-12-88$ & $120-1,632$ & \multirow{2}{*}{$\begin{array}{l}1.7,2.6 \mathrm{~g} / \mathrm{cm}^{3} \mathrm{a} \\
1.7,2.6 \mathrm{~g} / \mathrm{cm}^{3} \mathrm{~b} \\
1.7,2.6 \mathrm{~g} / \mathrm{cm}^{3 \mathrm{a}} \\
1.7,2.6 \mathrm{~g} / \mathrm{cm}^{3} \mathrm{~b}\end{array}$} \\
\hline & 2 & $09-21-88$ & $1,445-2,863$ & \\
\hline Gamma ray & 1 & $09-13-88$ & $0-1,629$ & $\begin{array}{l}80,190 \mathrm{c} / \mathrm{s}^{\mathrm{a}} \\
80,190 \mathrm{c} / \mathrm{s}^{\mathrm{b}}\end{array}$ \\
\hline $\begin{array}{l}\text { Spectral gamma ray } \\
\text { (includes potassium, uranium, thorium logs) }\end{array}$ & 1 & $09-21-88$ & $1,000-2,845$ & $\begin{array}{l}5,82,152 \mathrm{ppm}^{\mathrm{a}} \\
5,78,155 \mathrm{ppm}^{\mathrm{b}}\end{array}$ \\
\hline $\begin{array}{l}\text { Gyroscope } \\
\text { (50-ft stations) }\end{array}$ & $\begin{array}{l}1 \text { in } \\
1 \text { out }\end{array}$ & $\begin{array}{l}09-19-88 \\
09-19-88\end{array}$ & $\begin{array}{l}50-2,900 \\
25-2,925\end{array}$ & not calibrated \\
\hline $\begin{array}{l}\text { Induction electrolog } \\
\text { (includes spontaneous potential, conductance, } \\
\text { short-normal resistivity, and inductance) }\end{array}$ & 2 & $09-12-88$ & $1,458-2,832$ & $\begin{array}{l}2.064,10,484.5 \Omega \mathrm{m}^{\mathrm{a}} \\
2.164,10,484.5 \Omega \mathrm{m}^{\mathrm{b}} \\
2.059,10,485.6 \Omega \mathrm{m}^{\mathrm{a}} \\
2.045,10.1,488.9 \Omega \mathrm{m}^{\mathrm{b}}\end{array}$ \\
\hline Magnetometer & 1 & $09-13-88$ & $100-1,636$ & not calibrated \\
\hline Temperature & $\begin{array}{l}1 \\
2 \\
3\end{array}$ & $\begin{array}{l}09-09-88 \\
09-22-88 \\
09-27-88\end{array}$ & $\begin{array}{r}13-1,633 \\
38-2,837 \\
1,398-2,825\end{array}$ & $\begin{array}{l}67,80,95,107,123^{\circ} \mathrm{F}^{\mathrm{a}} \\
76,79,108,114^{\circ} \mathrm{F}^{\mathrm{b}}\end{array}$ \\
\hline Tracer survey & $\begin{array}{l}1 \\
2\end{array}$ & $\begin{array}{l}09-27-88 \\
09-27-88\end{array}$ & $\begin{array}{l}1,600-2,900 \\
1,600-2,900\end{array}$ & not calibrated \\
\hline
\end{tabular}

${ }^{\text {a }}$ Calibration prior to logging procedure.

${ }^{\mathrm{b}}$ Calibration after logging procedure. 


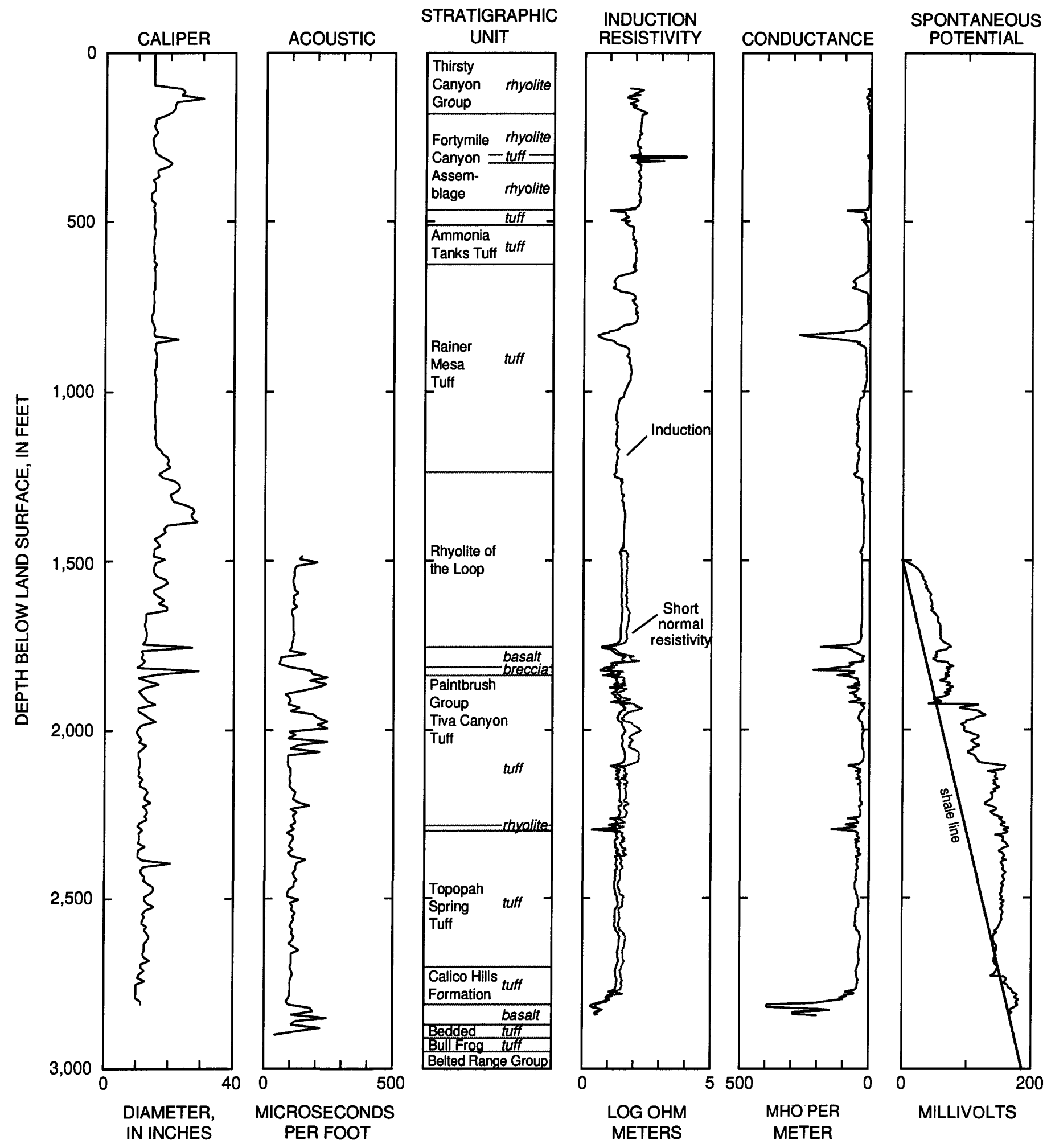

Flgure 3. Caliper, acoustic, geologic, and electric logs from Pahute Mesa-3 test well, Nye County, Nevada. 

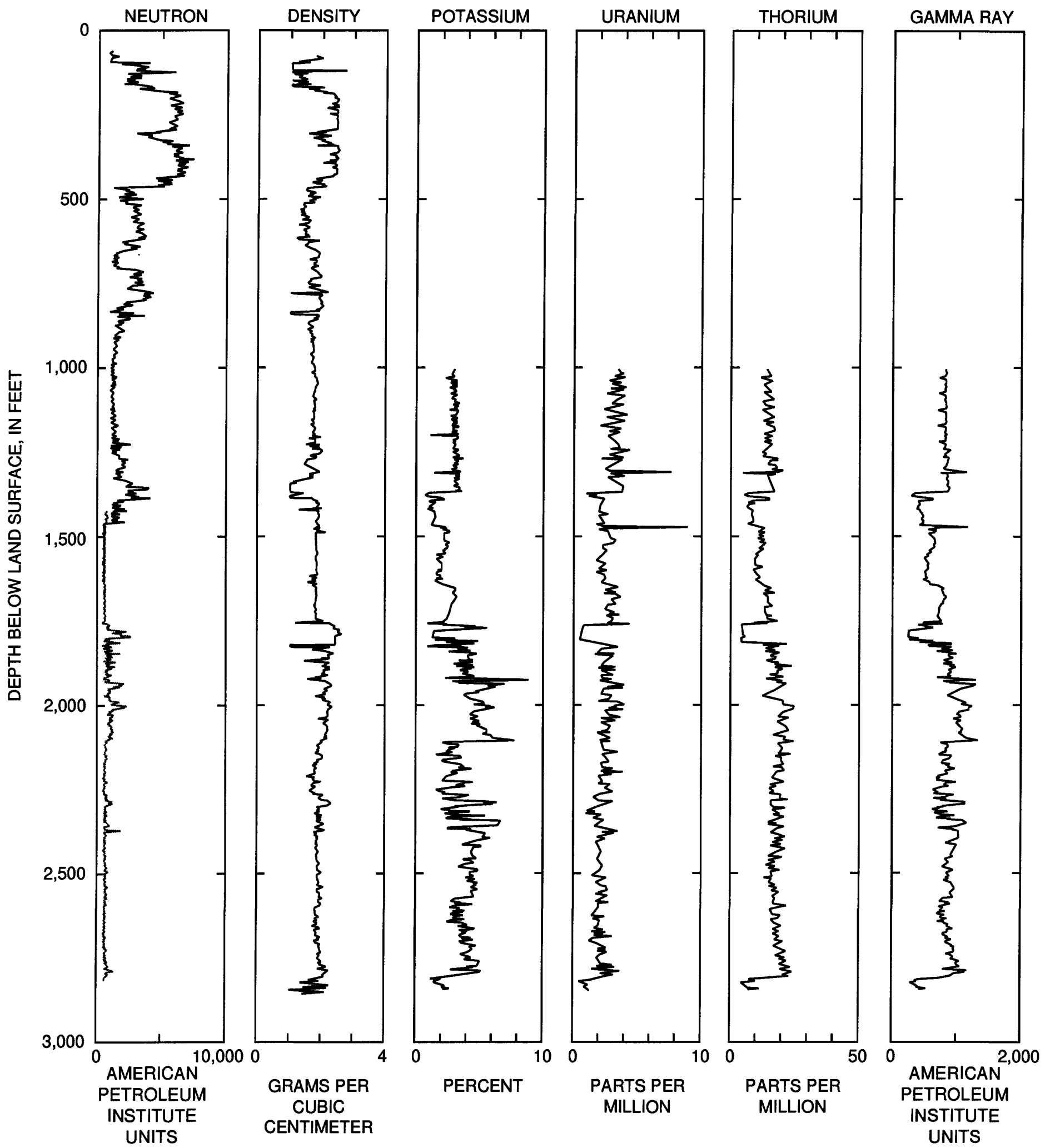

Figure 4. Nuclear logs from Pahute Mesa-3 test well, Nye County, Nevada. American Petroleum Institute units-Counting rates for gamma-ray and neutron logs are calibrated to a section of Indiana Limestone in Texas with a porosity of 19 percent. The section, exposed in a pit, is arbitrarily assigned a counting rate of 1,000 API units by the American Petroleum Institute. 


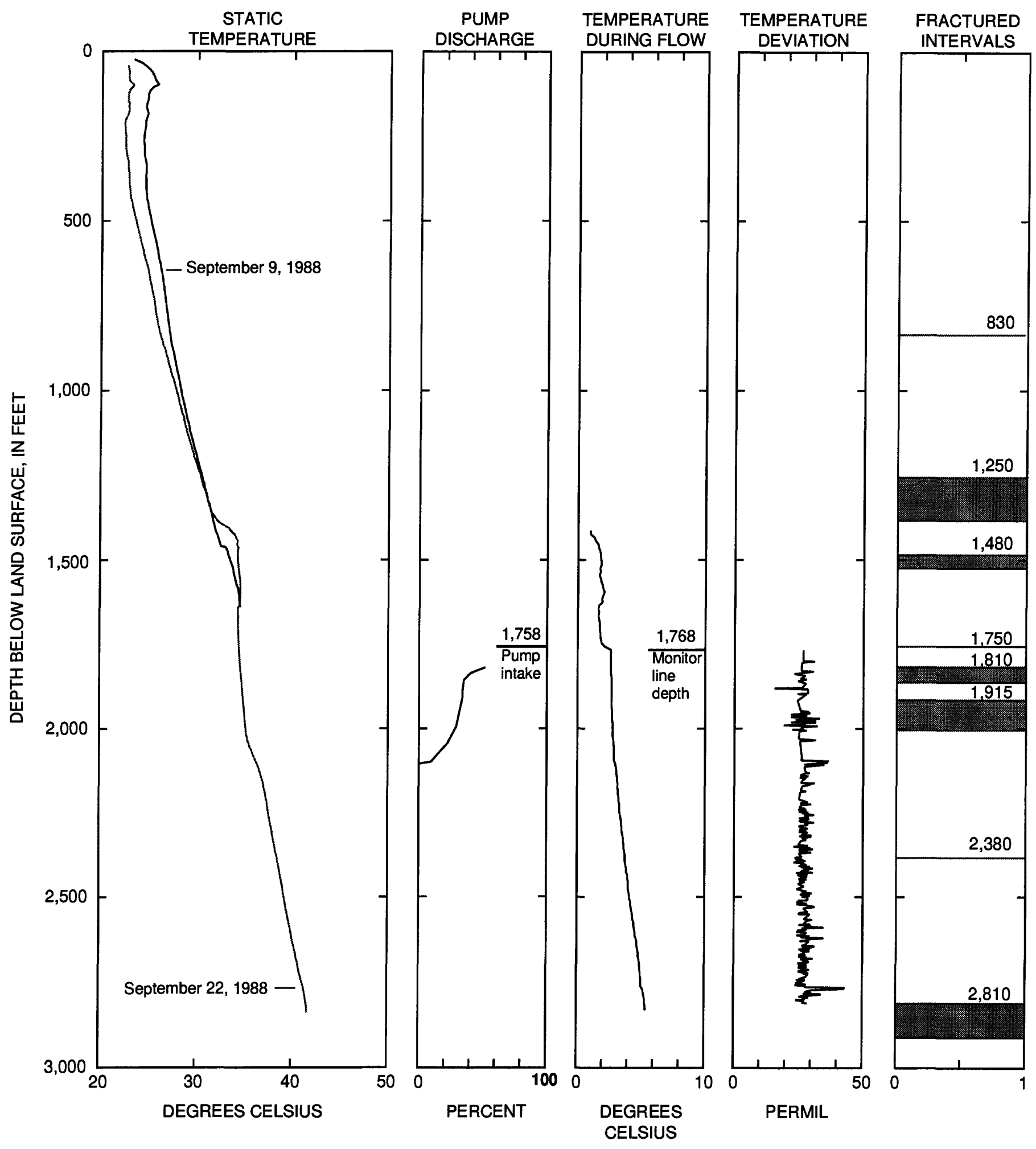

Figure 5. Temperature and tracer-test logs from Pahute Mesa-3 test well, Nye County, Nevada. 
was calibrated to within $0.1 \mathrm{in}$. of two endpoints before and after the logging. The hole was logged at a rate of $34 \mathrm{ft} / \mathrm{min}$.

The log (fig. 3) for the upper part of the hole, 0 to $124 \mathrm{ft}$, which was drilled with a 24 -in. bit shows the inside of the 16-in. surface casing. The log for the middle part of the hole, which was drilled with a 14.75-in. bit, shows a washout just below the surface casing from 90 to $175 \mathrm{ft}$ and soft or fractured zones at 300 and 830 $\mathrm{ft}$, and from 1,170 to $1,380 \mathrm{ft}$. The lower part of the hole, drilled with a 9.88-in. bit, shows a washout just below the casing from 1,470 to $1,640 \mathrm{ft}$ (not shown) and soft or fractured zones at depths of 1,750 and 1,810 $\mathrm{ft}$, from 1,950 to $1,980 \mathrm{ft}$, and from 2,450 to $2,490 \mathrm{ft}$. The average borehole diameter of the saturated interval of the well below the casing is 13.6 in.

\section{Acoustic}

The acoustic, or sonic, log shows the transit time of an acoustic pulse between transmitter and receiver in the probe (fig. 3 ). The acoustic log can only be run in fluid-filled segments of the borehole and is sensitive to borehole diameter changes unless it is borehole compensated. Sonic velocities are much slower in fluids than in solid rock, so the recorded velocities are proportional to the amount of fluid through which the signal passes. The chief uses of the acoustic log are for the measurement of primary and secondary porosity. Signals that arrive at the detector approximately 30 to $140 \mu \mathrm{s}$ after transmission generally are an indication of primary porosity, whereas signals arriving after $140 \mu \mathrm{s}$ traveled mostly through fluid and may indicate fractured media. The acoustic log for PM-3 was borehole compensated and calibrated to within $1 \mu \mathrm{s} / \mathrm{ft}$ at one endpoint before and after the log was completed. The hole was logged at a rate of $31 \mathrm{ft} / \mathrm{min}$.

The acoustic $\log$ (fig. 3) shows extremely slow transit times (greater than $140 \mu \mathrm{s} / \mathrm{ft}$ ) for the depth intervals from 1,480 to $1,520 \mathrm{ft}$, at $1,760 \mathrm{ft}$, from 1,810 to $1,880 \mathrm{ft}$, from 1,950 to $2,070 \mathrm{ft}$, at 2,220 and $2,380 \mathrm{ft}$, and from 2,810 to $2,911 \mathrm{ft}$. The slow traveltimes in interval from 1,480 to $1,520 \mathrm{ft}$ probably do not indicate a fracture, but a washout related to the lower edge of the casing at $1,480 \mathrm{ft}$. The others are interpreted to represent fractures or groups of fractures on the basis of caliper and acoustilog response. If we assume that the transit time in water is $190 \mu \mathrm{s} / \mathrm{ft}$ and the acoustic properties of tuffs are similar to those of sandstone, $60 \mu \mathrm{s} / \mathrm{ft}$ (Keys and MacCary, 1971, p. 90), then the effective porosity of the formation, $n_{e}$, may be calculated by

$$
n_{e}=\frac{t t-60}{190-60}
$$

where,

$t t$ is the transit time recorded on the log;

$60 \mu \mathrm{s}$ is the transit time in sandstone; and

$190 \mu \mathrm{s}$ is the transit time in water.

The results of these calculations are shown in table 4.

\section{Resistivity}

Resistivity-logging devices measure the electrical resistivity of an assumed volume of earth materials under the application of an alternating electric current. The resistivity of the rock depends on the amount and composition of the pore water, the shape of the pores or fractures, and the clay content of the rock. Fractures and faults may have very high resistivities if unfilled, or very low resistivities if filled with clay or fault gouge. The short-normal log (shown for the saturated part of the well only) gives good vertical detail, and records the apparent resistivity of the zone adjacent to the borehole invaded by drilling mud. The induction $\log$ records the apparent resistivity of the formation beyond the invaded zone. Resistivities are recorded on a logarithmic scale. The resistivity logs were each calibrated to within 0.01 log cycle against one endpoint before and after the borehole survey. The hole was logged at a rate of $63 \mathrm{ft} / \mathrm{min}$. Resistivity of drilling mud was $11 \Omega \mathrm{m}$ at $74^{\circ} \mathrm{F}$ during logging of the upper part of the hole, and $14 \Omega \mathrm{m}$ at $62^{\circ} \mathrm{F}$ during logging of the lower part of the hole.

The induction logs (fig. 3) show very high resistivity at $300 \mathrm{ft}$ in the tuff between the two rhyolite units in the Fortymile Canyon assemblage; the high resistivity probably indicates a washout of soft material. Both logs show low resistivity values at $460 \mathrm{ft}$, from 650 to $700 \mathrm{ft}$, from 810 to $850 \mathrm{ft}$, at $1,750 \mathrm{ft}$, from 1,810 to $1,820 \mathrm{ft}$, from 2,290 to $2,300 \mathrm{ft}$, and from 2,800 to $2,840 \mathrm{ft}$. Low values may indicate clay units or argillic alteration and lithologic contacts between softer tuffs, harder breccias, and flow units. Clay in fractures may be the result of the formation of fault gouge, and the association of clay with the tops of formations may indicate long periods of nondeposition when clays in soils developed. On the basis of this association and a lack of response on the caliper and acoustic logs, low values at $460 \mathrm{ft}$, from 650 to $700 \mathrm{ft}$, from 2,290 to $2,300 \mathrm{ft}$, and from 2,800 to $2,840 \mathrm{ft}$ are 
Table 4. Summary of porosity estimates for Pahute Mesa-3 test well, logged September 12,1988 , to September 20, 1988, Nye County, Nevada

[Effective porosity estimated from acoustic log. Total porosity estimated from gamma-gamma log.]

\begin{tabular}{|c|c|c|c|c|c|}
\hline $\begin{array}{c}\text { Interval } \\
\text { (feet below } \\
\text { land surface) }\end{array}$ & $\begin{array}{l}\text { Thickness } \\
\text { (feet) }\end{array}$ & $\begin{array}{l}\text { Effective } \\
\text { porosity } \\
\text { (percent) }\end{array}$ & $\begin{array}{c}\text { Total } \\
\text { porosity } \\
\text { (percent) }\end{array}$ & $\begin{array}{c}\text { Top of } \\
\text { unit }\end{array}$ & Notes \\
\hline $\begin{array}{l}0-93 \\
93-175 \\
175-300 \\
300 \\
300-460\end{array}$ & $\begin{array}{r}93 \\
82 \\
125 \\
160\end{array}$ & $\begin{array}{l}-- \\
-- \\
- \\
-- \\
--\end{array}$ & $\begin{array}{c}\overline{--} \\
\overline{12} \\
-- \\
12\end{array}$ & $\begin{array}{c}\text { Thirsty Canyon Group } \\
\text { do. } \\
\text { Fortymile Canyon assemblage } \\
\text { do. } \\
\text { do. }\end{array}$ & $\begin{array}{l}\text { surface casing } \\
\text { washout } \\
\text { rhyolite } \\
\text { soft zone } \\
\text { rhyolite }\end{array}$ \\
\hline $\begin{array}{l}460-505 \\
505-640 \\
640-770 \\
770 \\
770-830\end{array}$ & $\begin{array}{r}45 \\
135 \\
130 \\
60\end{array}$ & $\begin{array}{l}-- \\
-- \\
-- \\
-- \\
--\end{array}$ & $\begin{array}{r}55 \\
73 \\
55 \\
-- \\
46\end{array}$ & $\begin{array}{c}\text { Timber Mountain Group- } \\
\text { Ammonia Tanks Tuff } \\
\text { do. } \\
\text { do. } \\
\text { do. }\end{array}$ & $\begin{array}{l}\text { fracture nearby ? } \\
\text { fracture }\end{array}$ \\
\hline $\begin{array}{l}830 \\
830-1,170 \\
1,170-1,320 \\
1,320-1,380 \\
1,380-1,455\end{array}$ & $\begin{array}{r}340 \\
150 \\
60 \\
75\end{array}$ & $\begin{array}{l}-- \\
-- \\
-- \\
- \\
-\end{array}$ & $\begin{array}{r}-- \\
55 \\
55 \\
-- \\
46\end{array}$ & $\begin{array}{l}\text { do. } \\
\text { Rainer Mesa Tuff } \\
\text { Rhyolite of the Loop } \\
\text { do. } \\
\text { do. }\end{array}$ & $\begin{array}{l}\text { fracture/fault } \\
\text { soft zone } \\
\text { fractures } \\
\text { soft zone }\end{array}$ \\
\hline $\begin{array}{l}1,455 \\
1,455-1,640 \\
1,640-1,750 \\
1,750 \\
1,750-1,810\end{array}$ & $\begin{array}{r}185 \\
110 \\
60\end{array}$ & $\begin{array}{r}-- \\
35 \\
35 \\
-- \\
4\end{array}$ & $\begin{array}{r}- \\
46 \\
46 \\
-- \\
12\end{array}$ & $\begin{array}{l}\text { do. } \\
\text { do. } \\
\text { do. } \\
\text { do. } \\
\text { do. }\end{array}$ & $\begin{array}{l}\text { water table } \\
\text { soft zone } \\
\text { fracture } \\
\text { basalt }\end{array}$ \\
\hline $\begin{array}{l}1,810-1,835 \\
1,835-1,880 \\
1,880-1,950 \\
1,950-2,000 \\
2,000-2,070\end{array}$ & $\begin{array}{l}25 \\
45 \\
70 \\
50 \\
70\end{array}$ & $\begin{array}{c}-- \\
-- \\
19 \\
-- \\
23\end{array}$ & $\begin{array}{c}-- \\
-- \\
33 \\
-- \\
33\end{array}$ & $\begin{array}{c}\text { Paintbrush Group } \\
\text { Tiva Canyon Tuff } \\
\text { do. } \\
\text { do. } \\
\text { do. }\end{array}$ & $\begin{array}{l}\text { fractured breccia } \\
\text { fractures } \\
\text { fractures }\end{array}$ \\
\hline $\begin{array}{l}2,070 \\
2,070-2,170 \\
2,170-2,260 \\
2,260-2,300 \\
2,300-2,390\end{array}$ & $\begin{array}{r}100 \\
90 \\
40 \\
90\end{array}$ & $\begin{array}{l}\cdots \\
23 \\
35 \\
31 \\
31\end{array}$ & $\begin{array}{l}-- \\
33 \\
46 \\
33 \\
46\end{array}$ & $\begin{array}{c}\text { do. } \\
\text { do. } \\
\text { do. } \\
\text { do. } \\
\text { Topopah Spring Tuff }\end{array}$ & $\begin{array}{l}\text { fracture } \\
\text { rhyolite }\end{array}$ \\
\hline $\begin{array}{l}2,390-2,460 \\
2,460-2,490 \\
2,490-2,770 \\
2,770-2,810 \\
2,810-2,870 \\
\end{array}$ & $\begin{array}{r}70 \\
30 \\
280 \\
40 \\
60 \\
\end{array}$ & $\begin{array}{r}38 \\
23 \\
35 \\
27 \\
--\end{array}$ & $\begin{array}{l}46 \\
46 \\
46 \\
33 \\
27\end{array}$ & $\begin{array}{c}\text { do. } \\
\text { do. } \\
\text { do. } \\
\text { Calico Hills Formation } \\
\text { do. }\end{array}$ & fractured basalt \\
\hline $\begin{array}{c}\text { Mean } \\
\text { Weighted mean }\end{array}$ & 99 & $\begin{array}{l}28 \\
30\end{array}$ & $\begin{array}{l}41 \\
42\end{array}$ & & \\
\hline
\end{tabular}

interpreted to be paleosols. The intervals from 810 to $850 \mathrm{ft}$, and at $1,750 \mathrm{ft}$, are interpreted as fractures, and from 1,810 to $1,820 \mathrm{ft}$ is a breccia.

\section{Conductance}

Conductance, a measure of the ability of the formation to conduct electricity, can be measured in either a wet or a dry hole. Conductance use is limited in holes where the contrast in electrical conductivity between formation water and drilling mud is large. The conductance $\log$ is the inverse of the induction log. It was calibrated to within $1 \mathrm{mho} / \mathrm{m}$ at one endpoint at the beginning and end of logging. The hole was logged at $43 \mathrm{ft} / \mathrm{min}$.

The conductance log (fig. 3) displays features that are similar to those of the short-normal resistivity and induction logs. Clayey units are identified at $460 \mathrm{ft}$, from 650 to $700 \mathrm{ft}$, from 810 to $850 \mathrm{ft}$, at $1,750 \mathrm{ft}$, from 1,810 to $1,820 \mathrm{ft}$, from 2,290 to $2,300 \mathrm{ft}$, and from 2,800 to $2,840 \mathrm{ft}$. Conductance of the rest of the hole are generally less than $50 \mathrm{mhos} / \mathrm{m}$. 


\section{Spontaneous Potential}

Spontaneous-potential (SP) logs are records of the natural electrical potentials developed between the borehole fluid and the surrounding rock formations. The spontaneous potential is used for geologic correlation and determination of bed thickness. The signal is recorded directly in millivolts. The spontaneous-potential logging instrument cannot be calibrated as other instruments are calibrated because the SP signal has an inherent component of drift. A calibration based on the assumption that clay or shale units yield the lowest SP readings can be made by drawing a straight line, the "shale line," through the low points and measuring deflections from this line. The shale line is shown on the graph (fig. 3). The hole was logged at $43 \mathrm{ft} / \mathrm{min}$.

The SP $\log$ (fig. 3) has low values at $1,490 \mathrm{ft}$, from 1,900 to $1,920 \mathrm{ft}$, and at $2,725 \mathrm{ft}$. The low value at $1,490 \mathrm{ft}$ is because of the water table and bottom of the steel casing. The low SP at $1,920 \mathrm{ft}$ is in the middle of the Tiva Canyon Tuff of the Paintbrush Group, which is moderately welded, but only a small amount of clay is indicated at this level by the other electric logs. The low value at $2,725 \mathrm{ft}$ is in the Calico Hills Formation. Basalts from 1,750 to $1,800 \mathrm{ft}$ and from 2,810 to 2,870 $\mathrm{ft}$ are indicated by relative low values in the SP log. A large offset at $1,920 \mathrm{ft}$ is a contact between an overlying nonwelded and an underlying moderately welded ashflow tuff. The largest SP readings, at depths from 1,920 to $2,120 \mathrm{ft}$, are associated with the fractured interval of the Paintbrush Group.

\section{Nuclear Logs}

\section{Epithermal Neutron}

The neutron log shows the hydrogen content of the borehole environment. Hydrogen occurs principally as water in pores, water in fractures, clay minerals, and wide spots in the well bore. With a long-spaced probe, the number of neutrons measured is inversely proportional to the water content, so the neutron signal is significantly attenuated below the water table. The neutron probe was mounted with a decentralizing skid to minimize borehole effects. It was calibrated to three points before and after logging was completed. The hole was logged at a rate of approximately $29 \mathrm{ft} / \mathrm{min}$.

The neutron $\log$ (fig. 4) shows a large response at depths between 90 and $460 \mathrm{ft}$ that correlates well with two rhyolite lavas of Ribbon Cliff and indicates their low content of hydrous minerals or water. Large values in the interval from 1,220 to $1,380 \mathrm{ft}$ are in Rainer Mesa Tuff and Rhyolite of the Loop, but also may reflect borehole rugosity. Large values in the depth interval from 1,750 to $2,100 \mathrm{ft}$ are in basalt, breccia, and tuff, which may have lower clay content than other units. Low values from 460 to $510 \mathrm{ft}$, from 650 to $700 \mathrm{ft}$, from 800 to $830 \mathrm{ft}$, from 1,800 to $1,930 \mathrm{ft}$, and at $2,100 \mathrm{ft}$ correlate well with low values in the induction electrologs and may indicate clayey units, argillic alteration, and or high porosity.

\section{Density}

The density, or gamma-gamma log records the intensity of gamma radiation from a cesium- 137 source backscattered by the fluid, casing, and formation. The main uses of gamma-gamma logs are for identification of lithology, computation of bulk density, and estimation of porosity. Two sensors are used to determine and correct for the effect of borehole rugosity. The density $\log$ was borehole compensated. It was calibrated to two endpoints, 1.7 and $2.6 \mathrm{~g} / \mathrm{cm}^{3}$, before and after the survey. The curve delay of the instrument was $3 \mathrm{in}$. and the logging rate was $29 \mathrm{ft} / \mathrm{min}$.

The density log (fig. 4) shows unusually low densities in areas where the caliper log indicates washouts of the well bore from 93 to $175 \mathrm{ft}$, from 1,320 to 1,380 $\mathrm{ft}$, and suspected fractures at 830,1750 , and $1810 \mathrm{ft}$, and from 2,810 to $2,870 \mathrm{ft}$. These low values are an indication of the instrument sensitivity to differences in borehole diameter. Bulk density is highest, approximately 2.4 to $2.5 \mathrm{~g} / \mathrm{cm}^{3}$, where the hole penetrates basalt and rhyolite flows. Assuming a grain density of $2.65 \mathrm{~g} / \mathrm{cm}^{3}$ and water density of $1.00 \mathrm{~g} / \mathrm{cm}^{3}$, the total porosity, $n_{t}$, can be calculated from the equation:

$$
n_{t}=\frac{2.65-\rho}{2.65-1.00} \text {, }
$$

where $\rho$ is rock density measured on the geophysical $\log$. table 4.

The results of these calculations are shown in

\section{Spectral Gamma Ray}

The spectral gamma-ray log records natural gamma radiation as a function of a characteristic energy for each of the elements potassium, uranium, and thorium. The logs are helpful in distinguishing mafic from felsic volcanic units because all three elements are preferentially concentrated in felsic units, 
and for stratigraphic correlation. The potassium log also may be used to determine potassium content of the rock. The spectral logs were calibrated to within 2 percent, 1 and $15 \mathrm{ppm}$, respectively, of one endpoint before and after the logging run. The hole was logged at a rate of approximately $6 \mathrm{ft} / \mathrm{min}$ at depths from 2,848 to $1,000 \mathrm{ft}$ and no curve delay. The upper part of the borehole was not logged. The segment from 1,470 to $1,000 \mathrm{ft}$ was already cased and cemented at the time of logging.

All three curves (fig. 4) show an offset at $1,380 \mathrm{ft}$, which is correlated with a transition from fractured to unfractured units in the caliper log and may indicate a more mafic interval of tuffs. Low values in all three logs, particularly at depths from 1,750 to $1,810 \mathrm{ft}$ and from 2,810 to $2,848 \mathrm{ft}$, correlate with basalt flows. Uranium peaks occur at 1,300 and $1,465 \mathrm{ft}$. The peaks do not relate to any particular lithology, but the lower peak was recorded just below the water table, at $1,455 \mathrm{ft}$. An interval of relatively high potassium is indicated from 1,910 to $2,100 \mathrm{ft}$. The geologic $\log$ for this section indicates nonwelded to moderately welded, devitrified ash-flow tuff. This is the only segment of the spectral gamma-ray log interpreted as a devitrified unit, and it is roughly coincident with a zone of fractures identified on the acoustic and caliper logs at depths from 1,950 to $2,000 \mathrm{ft}$. Devitrification and fractures may be related, possibly due to increased velocity of water.

\section{Gamma Ray}

The gamma-ray, or natural gamma log, is used primarily to correlate units from one borehole to another and to identify lithology. The gamma-ray log measures total radiation from natural radioactive isotopes of potassium, thorium, and uranium. The gamma-ray log was calibrated to one endpoint, 9,200 \pm 100 American Petroleum Institute units, before and after the log was completed. The hole was logged at a rate of approximately $6 \mathrm{ft} / \mathrm{min}$ from 2,848 to $1,000 \mathrm{ft}$.

The gamma-ray log (fig. 4) shows low values corresponding to the two basalt units at depths from 1,750 to $1,810 \mathrm{ft}$ and from 2,810 to $2,848 \mathrm{ft}$. The $\log$ also shows low values from 1,360 to $1,470 \mathrm{ft}$ that are mapped as nonwelded ash-flow tuff. This interval corresponds to a zone where the borehole was larger in diameter and the annulus was filled with cement when the casing was set. Anomalous high values are found from 1,910 to $2,100 \mathrm{ft}$. Sidewall core samples collected in this interval indicate no unusual concentrations of radioactive material.

\section{Borehole Flow Survey}

\section{Temperature Prior to Tracer Survey}

Temperature logs were recorded about 2 weeks apart and show the effects of thermal equilibration of the well water with the aquifer following well construction. The flat geothermal gradient (note that a vertical line on the graph is a flat geothermal gradient) between 0 and $500 \mathrm{ft}$ appears to be due to surface temperature effects in the well bore and unsaturated zone. Steepening of the slope of the temperature profile at a depth of approximately $1,456 \mathrm{ft}$ is interpreted to represent the water level in the well. Temperatures between about 1,400 and $2,100 \mathrm{ft}$ change little, so that water is warmer than a linear geothermal gradient would indicate. Such a flattening of the temperature profile may be caused by rocks with high thermal conductivity or it may indicate upward vertical flow of warm water in the well bore. A basalt flow is located approximately in the middle of the flat gradient; however, its thickness, $60 \mathrm{ft}$, is much smaller than the anomaly, which spans approximately 700 vertical $\mathrm{ft}$. The other rock types in the interval are unwelded to moderately welded ash-flow tuffs, fractured ash-flow tuffs, and fractured tuff breccia. The thermal conduction properties of the basalt are unknown, but its small thickness and the homogeneous composition of the tuffs above and below the basalt suggest that the thermal conductivity of the rocks does not cause this flattening of thermal gradient. A more likely interpretation is that the basalt, which is shown by caliper and acoustic logs to be unfractured, acts as a confining layer to the highly fractured units below it and that flow of heat or water in the borehole is upward. An upward hydraulic gradient is not, however, indicated by differences in hydraulic head with depth. Temperatures below 2,100 $\mathrm{ft}$ approximate the average geothermal gradient for the entire well.

Temperature gradient of the well is the difference between the bottom hole temperature and the mean annual air temperature divided by the well depth expressed in degrees Celsius per $100 \mathrm{ft}$. The temperature gradient at PM-3 is high compared to other wells on Pahute Mesa. Using an estimated mean annual air temperature of $13^{\circ} \mathrm{C}$, the $\mathrm{PM}-3$ temperature gradient was calculated to be $1.00^{\circ} \mathrm{C} / 100 \mathrm{ft}$. Only the temperature gradient at well $\mathrm{PM}-2,1.31^{\circ} \mathrm{C} / 100 \mathrm{ft}$, is larger than the one at PM-3. Temperature gradient at other wells on Pahute Mesa range from 0.52 to $0.88^{\circ} \mathrm{C} / 100 \mathrm{ft}$. 
The high temperature gradient at PM-2 was thought by Blankennagel and Weir (1973) to result from remnant heat in granite penetrated at a depth of $8,400 \mathrm{ft}$.

\section{Tracer Survey}

A borehole-flow survey was done in the depth interval from 1,768 to $2,170 \mathrm{ft}$, in which fluid velocity and temperature within the well bore was measured during pumping to identify transmissive intervals of the aquifer. A short-lived radioactive tracer, iodine-131, was injected into the borehole from the geophysical "tracer." The iodine concentration was measured as it moved with the borehole fluid past a set of detectors. Fluid velocity was calculated from the time it took for the peak concentrations to move from detector to detector (Dresser Atlas, 1982). This method works best in small-diameter wells in low transmissivity aquifers. It is most sensitive to areas between the pump intake and the nearest highly transmissive zone. Such surveys generally give little information about segments of the well away from the pump intake. The first tracer survey was made with a 5 -ft spacing between the detectors. Few iodine readings were obtained in this configuration. A second survey was made with the detectors spaced $3 \mathrm{ft}$ apart. The $3-\mathrm{ft}$ spacing increased the number of iodine peaks detected. Fluid velocity and hole diameter were used to compute aquifer discharge along the study interval. The discharge readings are expressed as a percentage of the average pump discharge, $169 \mathrm{gal} / \mathrm{min}$ (fig. 5). Depth intervals in which the percentage of pump discharge differs by a large amount with depth are the most transmissive.

The tracer survey indicated no vertical flow in the well below $2,170 \mathrm{ft}$, although flow less than a few percent over such a large interval could not be detected by this method. The depth interval from 2,100 to $2,170 \mathrm{ft}$ produced less than 1 percent of the flow. The interval from 1,975 to $2,100 \mathrm{ft}$ produced 30 percent of the pumping discharge, indicating a more transmissive unit. The interval between 1,850 and $1,975 \mathrm{ft}$ produced only 4 percent of the flow, indicating that transmissivity is low. The interval from 1,812 to $1,850 \mathrm{ft}$ produced 18 percent of flow and is considered to be highly transmissive. The tracer survey could not be made above the monitor-line portal, but the remaining flow (48 percent) is presumed by difference to have originated from this interval $(1,455$ to $1,758 \mathrm{ft})$. This interpretation indicates moderate transmissivity for the interval, but does not rule out the possibility that some high transmissivity units are interbedded with low transmissivity units.

\section{Temperature During Pumping}

The temperature survey made concurrently with the tracer survey also is shown on figure 5. For such a survey, flow is downward in the well bore above the pump intake and upward in the well bore below it during pumping. Because the tracejector and temperature probes were emplaced through a monitor tube with a portal $10 \mathrm{ft}$ below the pump intake, only the well bore below the pump intake was monitored by the tracejector. Temperatures measured above the pump intake were made from inside the monitor tube adjacent to the pump motor and probably are not accurate. Zones in which the temperature is cooler than the static gradient indicate downward flow in the well bore and those in which temperature is warmer indicate upward flow.

The temperature and temperature deviation logs yield little information about flow to the well bore below $2,100 \mathrm{ft}$ that cannot be attributed to the static gradient and measurement error, but the logs confirm the possibility that, in this test configuration, little water that reaches the pump is coming from this depth. Above $2,070 \mathrm{ft}$ the thermal gradient flattens, indicating upward flow from this zone. The thermal gradient is relatively constant from $2,070 \mathrm{ft}$ to the pump intake.

\section{Discussion}

The caliper, resistivity, neutron, and density logs indicate friable zones in the unsaturated zone are at depths of 300 and $610 \mathrm{ft}$, and that fractures or faults are at 830 and $1,380 \mathrm{ft}$. The spectral-gamma, and gammaray traces also indicate an accumulation of uranium at $1,380 \mathrm{ft}$. Below the water table, the logs indicate fractured intervals from 1,810 to $1,880 \mathrm{ft}$, from 1,950 to $2,000 \mathrm{ft}$, and from 2,810 to $2,911 \mathrm{ft}$. The two intervals of large hydraulic conductivity indicated by the tracer test, from 1,812 to $1,850 \mathrm{ft}$ and from 1,990 to $2,100 \mathrm{ft}$ coincide closely with two intervals of intense fracturing. The Tiva Canyon Tuff, which is nonwelded to moderately welded, appears to be an important water transmitter. The rhyolite flow units are not fractured, but the Fortymile Canyon assemblage is associated with washouts just above and below. The basalts are associated with fractures and each overlies a formation that may be topped by a soil or rubble zone. The basalt 
of U-19ac appears to confine the Paintbrush Group so that flow is upward along the borehole from the Paintbrush Group to the units above.

The potassium log shows three intervals of increasing potassium content with depth: from 2,570 to $2,800 \mathrm{ft}$, from 2,100 to $2,360 \mathrm{ft}$, and from 1,800 to $2,100 \mathrm{ft}$. They are separated by zones of relatively constant potassium content. Each of the three intervals is bounded at the top or bottom by a flow unit. The transitions probably reflect decreasing silica saturation due to venting of a subcaldera magma chamber, but these do not coincide with specific lithologic units. The potassium logs may have great importance for regional stratigraphic correlation.

A buried granite intrusion was penetrated by PM-2 at 8,400 ft, only 7 mi north of PM-3. High heat flow may indicate buried granite at depth below PM-3 also.

\section{INJECTION TESTS}

\section{Analytical Methods}

The injection tests were analyzed by using the method proposed by Cooper and others (1967). Their analysis was based on an assumption of radial flow from the injection well into the formation. This method was chosen because (1) it is conceptually simple, (2) radial flow seems probable in light of the small volumes injected and large $(\sim 200-\mathrm{ft})$ intervals tested, and (3) it is based on the same geometric and mathematical assumptions as the method used to interpret the aquifer-test results. The assumption of radial flow does not always yield satisfactory results for other NTS injection tests however, particularly in highly fractured units (D.L. Galloway, U.S. Geological Survey, oral commun., 1989). The assumption that transmissivity calculated by this method represents primarily the interval tested seems satisfactory considering the small volumes injected and large intervals tested.

The method of Cooper and others (1967) requires that hydraulic head and time be measured during the test, and radii of the well and delivery tubing be known. Hydraulic head in the injection conduit is measured with a pressure transducer and declines nonlinearly throughout the test. Head values may vary from a few feet to hundreds of feet in most injection tests. In order to standardize head values for the type-curve match, the ratio of $\mathrm{H}(\mathrm{t}) / \mathrm{H}_{0}$ where, $\mathrm{H}(\mathrm{t})$, is the head in the injection conduit at time, $t$, due to the injection, and $\mathrm{H}_{0}$ is the initial head due to injection. The ratio is plotted against time after the start of injection $t$ on semilog graph paper. The delivery-tube radius, $r_{a}$, was $0.102 \mathrm{ft}$ for all injection tests. The well radius $r_{w}$ (measured with calipers over the total tested interval of the well) averaged $0.567 \mathrm{ft}$. Averages for specific intervals tested were used in the calculations.

Storage coefficient for the units penetrated by the test well is not known; however, a match to a type curve with a given $\alpha$ value may be used to make an order-of-magnitude estimate. A value of storage coefficient was estimated for each tested interval except interval D (see fig. 6). The plotted injection test data were matched with a type curve by superimposing the two plots along parallel y-axes. A matchline was chosen and the appropriate information taken from the type curve and the injection test plot.

Transmissivity was calculated by using the equation,

$$
T=\frac{1,440 t_{r} r_{a}^{2}}{t}
$$

where,

$T$ is the transmissivity, in feet squared per day;

1,440 is a factor to convert minutes to days;

$r_{a}$ is the delivery-tube radius, in feet;

$t_{r}$ is the matchline from the type curve, dimensionless; and

$t$ is the matchline from the injection-test data, in minutes.

Hydraulic conductivity, $K$, was calculated from the equation,

$$
K=\frac{T}{b}
$$

where $\mathrm{b}$ is the test interval, in feet.

Storage coefficient, $S$, was calculated by using the equation,

$$
S=\frac{\alpha r_{a}^{2}}{r_{w}^{2}},
$$

where,

$\alpha$ is a component related to storage between $10^{-1}$ and $10^{-5}$;

$r_{w}$ is the radius of the screened interval or uncased well.

The specific storage for an interval was calculated by dividing the storage coefficient by the interval thickness. 


\section{Test Conditions}

Injection tests were made to determine the hydraulic properties of six depth intervals in the test well. The depth intervals were selected on the basis of results of the borehole-flow survey. Three intervals, $\mathrm{A}$, $\mathrm{B}$, and $\mathrm{C}$, from 1,473 to $1,667 \mathrm{ft} ; 1,665$ to $1,865 \mathrm{ft}$; and 1,886 to $1,933 \mathrm{ft}$, respectively, were tested with a straddle-packer assembly (fig. 6). The packer assembly became lodged in the test well after the third injection test. After several days the assembly was dislodged, but was damaged and required factory repair. The $\mathrm{D}$ and $\mathrm{F}$ intervals, from 1,934 to $2,134 \mathrm{ft}$ and from 2,390 to $2,550 \mathrm{ft}$ respectively, were tested with a bridge plug and single packer. The bridge plug and single packer allowed more flexibility in selecting test intervals, but required more operating time than the straddle packer assembly. Interval $\mathrm{E}$ was not tested. The last interval, $\mathrm{G}$, was tested with only a single packer set at $2,550 \mathrm{ft}$ and although the hole originally extended to $3,019 \mathrm{ft}$, the well had collapsed to $2,605 \mathrm{ft}$ at the time of the test.

Pressure data were recorded on site by a contractor, who provided the packers. The pressure data were collected from above, between, and below the straddle packer assembly with crystal transducers during the

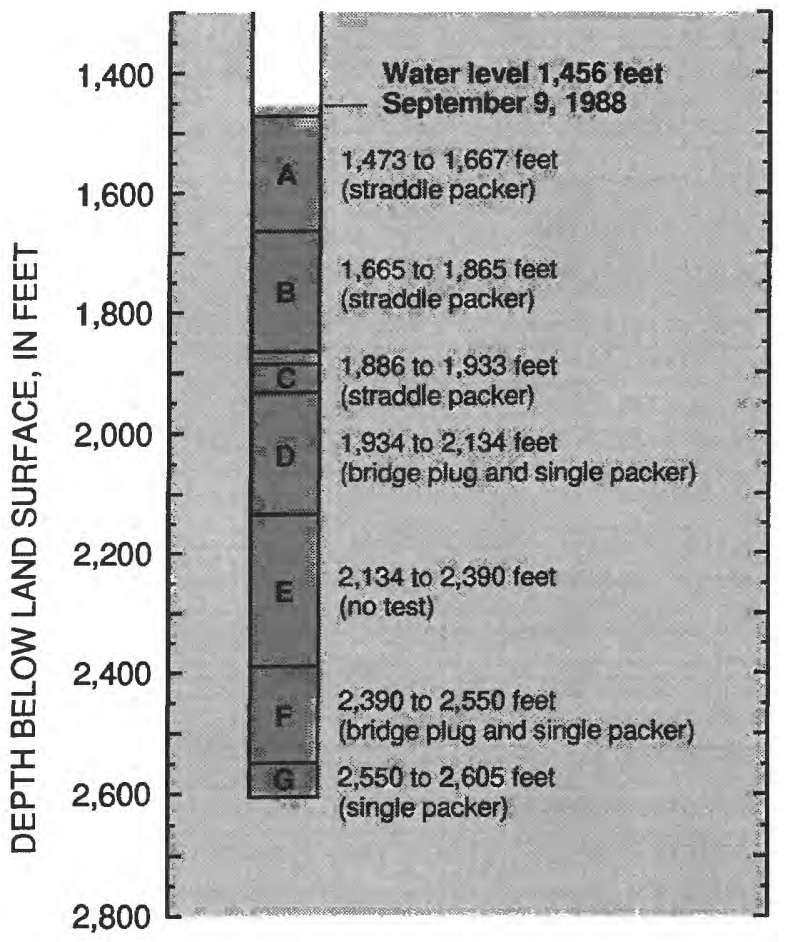

Figure 6. Intervals isolated by packers during injection testing, Pahute Mesa-3 test well, Nye County, Nevada. first three tests, and from above and between the packers on the last three tests. Pressure data were recorded at small time intervals of several seconds at the beginning of each test and at longer intervals as the test went on. The instantaneous maximum at the beginning of each injection test was determined by extrapolation. Injection tests were terminated when pressure reached equilibrium with pre-injection conditions, when a plot of pressure against elapsed time reached an inflection point, or when the test had extended beyond the time estimated to be necessary from preliminary calculations. The vertical hydraulic-head gradient, indicated by the difference in head at two depth intervals of the well, could not be defined because only one injection test reached equilibrium.

Water samples were collected from intervals B and $\mathrm{C}$; however, the samples were muddy and a large amount of formation debris accumulated above the lower packer after each sample. Presumably the suction placed on the wall of the well by the sampler was greater than the formation material could withstand. Sampling was discontinued after the straddle packer assembly became lodged in interval $\mathrm{C}$.

\section{Test Results}

\section{Interval A}

Interval $\mathrm{A}$, from 1,473 to $1,667 \mathrm{ft}$, is near the top of the thermal anomaly recorded on the temperature logs. Lithology in this interval consists of nonwelded, zeolitized ash-flow and reworked tuffs of the Rhyolite of the Loop member of the Timber Mountain Group. Fractures were detected in the upper part of this interval. The top packer was set in the bottom of the casing to prevent overinflation and to provide a tight fit; however, this meant that the top of the interval was only 18 $\mathrm{ft}$ below the static water level. Water was added to raise the hydraulic head in the delivery tubing $253 \mathrm{ft}$ above the formation water level of $1,455 \mathrm{ft}$. Three attempts to do the test produced poor results. During the first two tests, the time steps used were too large to adequately document the rapid water-level declines observed. The third test was made with an adequate time step; however, the pressure transducer had been placed too high in the access port and was left dry after only 19 minutes, and water level did not drop smoothly as it did in other tests. Results of the third injection test are shown in figure 7. 

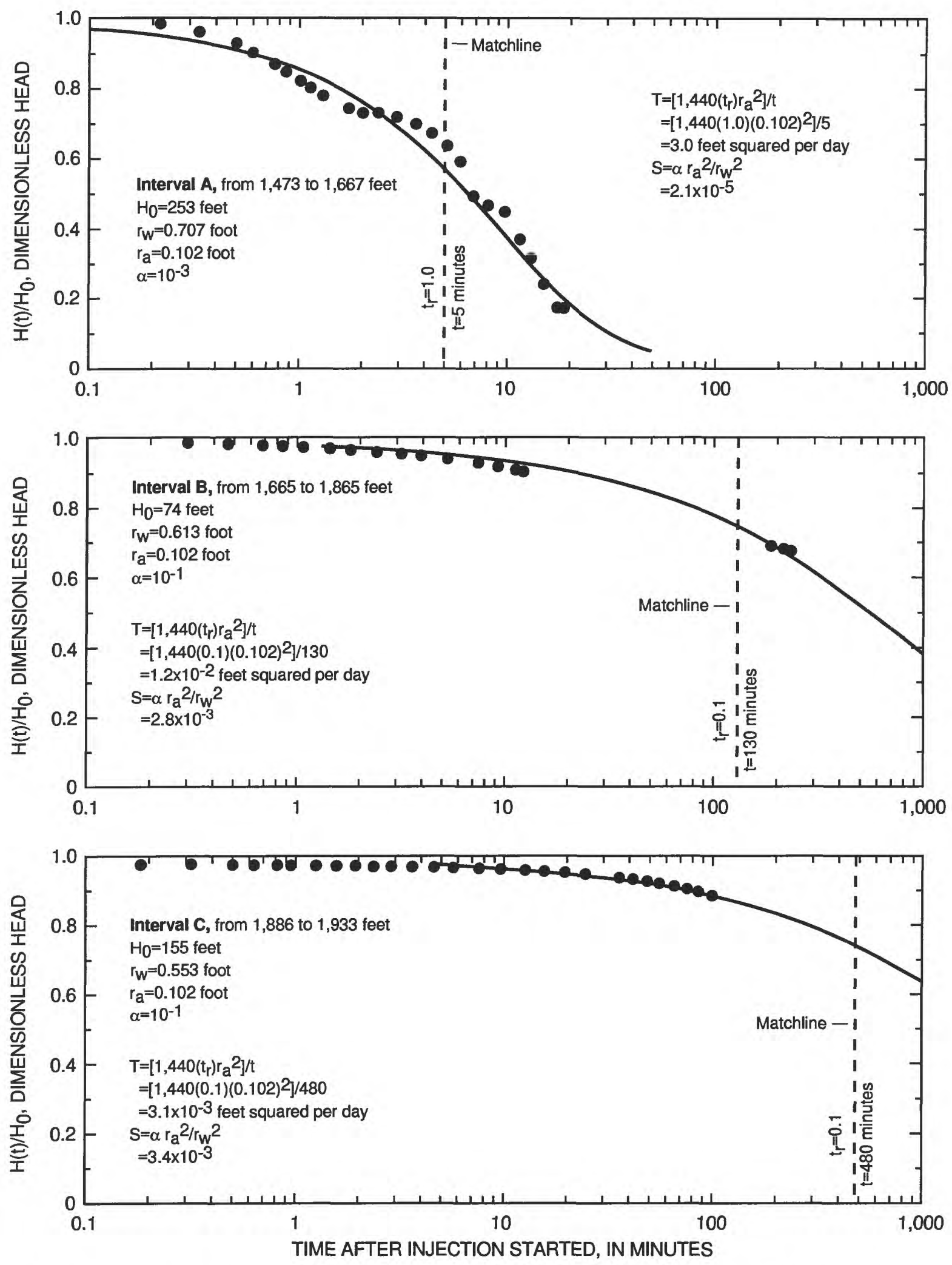

Figure 7. Injection-test analyses for depth intervals A, B, and C for Pahute Mesa-3 test well, Nye County, Nevada. Abbreviations: $T$, transmissivity; $S$, storage coefficient; $H(t)$, head in the well above initial head at the time since injection; $\mathrm{H}_{0}$, head in the well above initial head at the instant of injection; $r_{w}$, radius of open interval of well; $r_{a}$, delivery tube radius; $\alpha$, alpha; $t_{p}$, matchline from type curve; $t$, time. 
The data matched the type curve for $\alpha=10^{-3}$. The matchline was at $t=5$ minutes and $t_{r}$ the dimensionless time factor from the type curve, was 1.0. Transmissivity for rocks in this interval is a moderately large $3 \mathrm{ft}^{2} / \mathrm{d}$ and hydraulic conductivity is $1.5 \times 10^{-2} \mathrm{ft} / \mathrm{d}$. Storage coefficient is $2.1 \times 10^{-5}$ and specific storage is $\left(1.1 \times 10^{-7}\right) / \mathrm{ft}$. The small storage coefficient shows that this uppermost interval responds as a confined unit.

\section{Interval B}

Interval $\mathrm{B}$, from 1,665 to $1,865 \mathrm{ft}$, was selected because it is near the middle of the interval in which a thermal anomaly was detected by the temperature survey. The 200 -ft interval consists of nonwelded, zeolitized reworked tuffs, ash-flow tuffs, basalt, and tuff breccia of the Rhyolite of the Loop member of Timber Mountain Group and the upper part of the Tiva Canyon Tuff of the Paintbrush Group. The breccia and units below appear to be fractured. Results of the injection test are shown on figure 7. Water was added to raise the hydraulic head in the delivery tubing $74 \mathrm{ft}$ above the estimated formation water level of $1,456 \mathrm{ft}$. The test was 233 minutes, but this was not long enough to reach equilibrium. No data were recorded between 12 and 188 minutes because of communication problems between the pressure transducers and the recording instruments.

The data best matched the type curve for $\alpha=10^{-1}$, although an inflection point was never reached. The matchline was $t=130$ minutes for the injection test data and $t_{r}=0.1$. Transmissivity for rocks in this interval was calculated to be $1.2 \times 10^{-2} \mathrm{ft}^{2} / \mathrm{d}$ and hydraulic conductivity was $6.0 \times 10^{-5} \mathrm{ft} / \mathrm{d}$. Storage coefficient was estimated to be $2.8 \times 10^{-3}$ and specific storage was $\left(1.4 \times 10^{-5}\right) / \mathrm{ft}$.

\section{Interval C}

Interval C from 1,886 to $1,933 \mathrm{ft}$, was selected to determine the hydraulic properties associated with the lower part of a thermal anomaly on the temperature log. The 47-ft interval is composed entirely of nonwelded to partly welded ash-flow tuffs of the Tiva Canyon Tuff of the Paintbrush Group. No fractures were intersected in this interval. Water was added to raise the hydraulic head in the delivery tubing $155 \mathrm{ft}$ above the estimated formation water level of $1,455 \mathrm{ft}$. The injection test was 100 minutes (fig. 7). The test was not continued to equilibrium or to the inflection point because the estimated time was too long.
The injection-test data for this interval matched the type curve for $\alpha=10^{-1}$. The matchline was at $t=480$ minutes and $t_{r}=0.1$. Transmissivity was calculated to be $3.1 \times 10^{-3} \mathrm{ft}^{2} / \mathrm{d}$ and hydraulic conductivity was $6.6 \times 10^{-5}$ $\mathrm{ft} / \mathrm{d}$. Storage coefficient was estimated to be $3.4 \times 10^{-3}$ and specific storage was $\left(7.2 \times 10^{-5}\right) / \mathrm{ft}$.

\section{Interval D}

Interval D, from 1,934 to $2,134 \mathrm{ft}$, was selected to determine the hydraulic properties for the source of inflow indicated by the temperature $\log$ between 1,900 and 2,100 ft. The interval consists of the Tiva Canyon Tuff of the Paintbrush Group, a nonwelded to densely welded ash-flow tuff. Fractures were mapped from 1,915 to $2,000 \mathrm{ft}$ and at $2,070 \mathrm{ft}$. Water was added to raise hydraulic head in the delivery tubing $122.5 \mathrm{ft}$ above the estimated formation water level of $1,455 \mathrm{ft}$ (fig. 8). The injection test was run for 18 minutes, at which time the injection water reached equilibrium with the formation water.

The data did not match any of the type curves for radial flow, but matched a curve for a line source by Cooper and others (1967). The matchline was at $t=0.6$ minutes and $t_{r}=1.0$. Transmissivity was calculated to be $25 \mathrm{ft}^{2} / \mathrm{d}$ and hydraulic conductivity was $1.2 \times 10^{-1} \mathrm{ft} / \mathrm{d}$. Storage coefficient and specific storage were not calculated.

\section{Interval E}

Interval $\mathrm{E}$, from 2,134 to $2,390 \mathrm{ft}$, was not tested because no inflow or outflow was indicated by the constant temperature gradient. It includes the hornblende rhyolite and breccia in the Calico Hills Formation. No fractures were identified in this interval.

\section{Interval F}

Interval $\mathrm{F}$, from 2,390 to $2,550 \mathrm{ft}$, was selected to determine the hydraulic properties of the units above a small change in the temperature gradient at $2,550 \mathrm{ft}$. The 160-ft interval is composed of the Topopah Spring Tuff of the Paintbrush Group, a zeolitized nonwelded ash-flow tuff. Fractures were not found in this interval. Water was added to raise the hydraulic head in the delivery tubing $535 \mathrm{ft}$ above the estimated formation water level of $1,455 \mathrm{ft}$ (fig. 8). The injection test was run for almost 430 minutes. The test was not continued to equilibrium because the time was too long, but an inflection point was reached. 

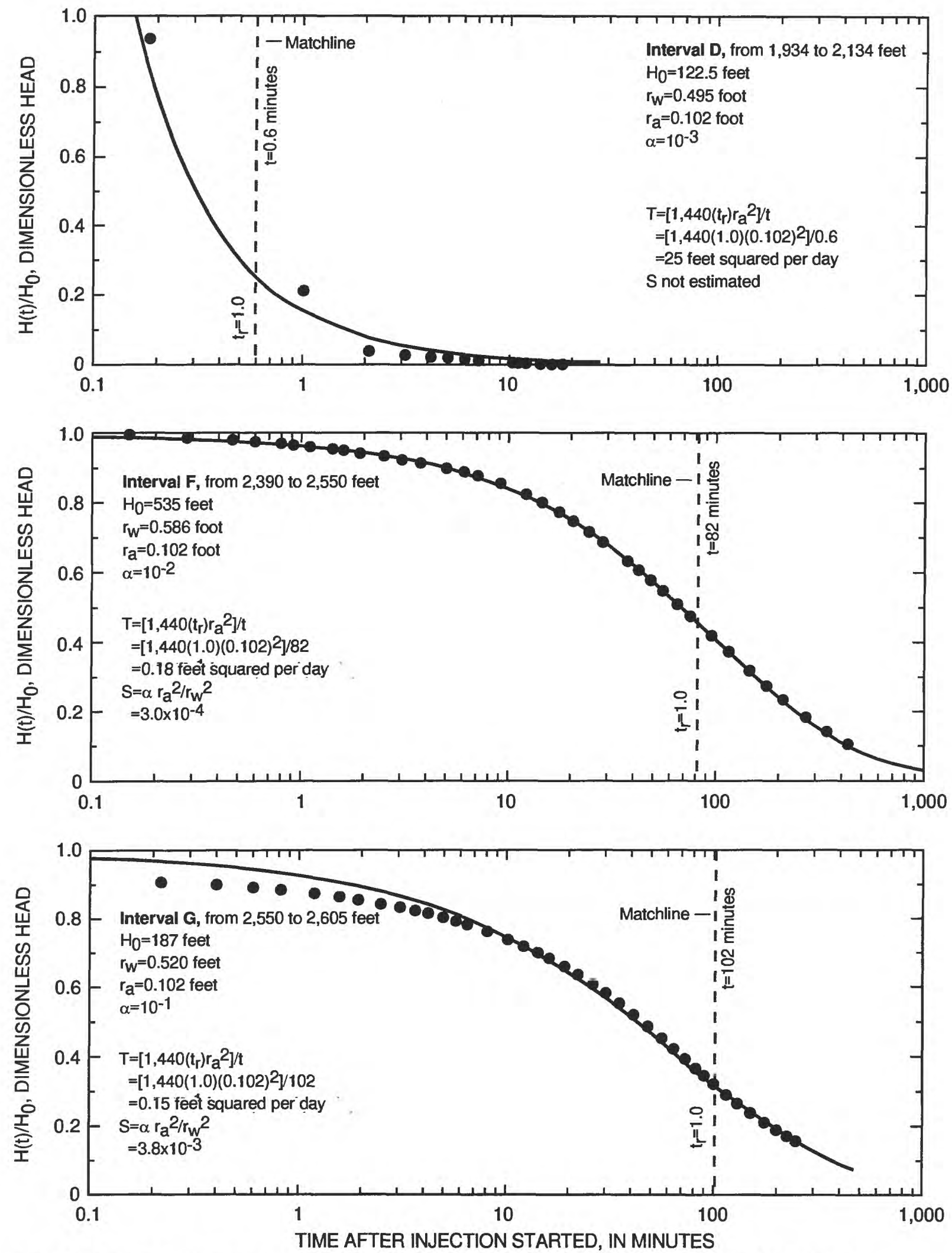

Figure 8. Injection-test analyses for depth intervals D, F, and G for Pahute Mesa-3 test well, Nye County, Nevada. Abbreviations: T, transmissivity; $S$, storage coefficient; $H(t)$, head in the well above the initial head at the time since injection; $\mathrm{H}_{0}$, head in the well above initial head at the instant of injection; $r_{w}$, radius of screened interval; $r_{a}$, delivery tube radius; $\alpha$, alpha; $t_{r}$, matchline from type curve; $t$, time 
The test data matched the type curve for $\alpha=10^{-2}$. The matchline was $t=82$ minutes and $t_{r}=1.0$. Transmissivity was calculated to be $0.18 \mathrm{ft}^{2} / \mathrm{d}$ and hydraulic conductivity was $1.1 \times 10^{-3} \mathrm{ft} / \mathrm{d}$. Storage coefficient was estimated to be $3 \times 10^{-4}$ and specific storage was $\left(1.9 \times 10^{-6}\right) / \mathrm{ft}$.

\section{Interval G}

Interval $\mathrm{G}$, from 2,550 to $2,605 \mathrm{ft}$, was tested with a single packer set at $2,550 \mathrm{ft}$. Although the well had been drilled to $3,019 \mathrm{ft}$, collapse of material into the well bore during previous injection tests resulted in a shorter interval for the test. The 55-ft interval was selected to determine the hydraulic properties of the units below a small change in the temperature gradient at 2,550 ft. The interval penetrates nonwelded to densely welded air-fall and ash-flow tuffs of the Topopah Spring Tuff of the Paintbrush Group. Water was added to raise the hydraulic head in the delivery tubing $187 \mathrm{ft}$ above the estimated formation water level of $1,455 \mathrm{ft}$ (fig. 8). The injection test was run for 250 minutes. The test was not continued to equilibrium because the time was too long, but an inflection point was reached.

The test data matched the type curve for $\alpha=10^{-1}$. The matchline was $t=102$ minutes and $t_{r}=1.0$. Transmissivity was calculated to be $0.15 \mathrm{ft}^{2} / \mathrm{d}$ and hydraulic conductivity was $2.7 \times 10^{-3} \mathrm{ft} / \mathrm{d}$. Storage coefficient was estimated to be $3.8 \times 10^{-3}$ and specific storage was $\left(6.9 \times 10^{-5}\right) / \mathrm{ft}$.

\section{Discussion}

The results of the injection tests are shown in table 5. For the six tested intervals, A, B, C, D, F, and $\mathrm{G}$, transmissivity varied more than four orders of magnitude, from $3.1 \times 10^{-3}$ to $25 \mathrm{ft}^{2} / \mathrm{d}$, and hydraulic conductivity varied from $6.0 \times 10^{-5}$ to $1.2 \times 10^{-1} \mathrm{ft} / \mathrm{d}$. These values are small compared with the range of hydraulic conductivity for fractured igneous rocks reported by Freeze and Cherry $(1979$, p. 29$)$ of $10^{-2}$ to $10^{2} \mathrm{ft} / \mathrm{d}$. Only intervals $A$ and $D$ are within this range and only intervals $A, B$, and $D$ intersect significant zones of fractures. Intervals $A, B$, and $D$ also were identified by the tracer survey as being most productive. Interval $B$, from 1,665 to $1,865 \mathrm{ft}$, had a low hydraulic conductivity, $6.0 \times 10^{-5} \mathrm{ft} / \mathrm{d}$. It includes the interval from 1,810 to $1,880 \mathrm{ft}$ that was fractured and also showed flow during the tracer test. The reason for its low hydraulic conduc- tivity is not known. Intervals $\mathrm{C}, \mathrm{F}$, and $\mathrm{G}$ had no fractures, and relatively low to moderate hydraulic conductivity.

Lohman (1972, p. 8) reported a range in specific yield of 0.1 to 0.3 for most unconfined aquifers and a range in storage coefficient of $10^{-5}$ to $10^{-3}$, which is about $10^{-6}$ per $\mathrm{ft}$ of aquifer thickness, for most confined aquifers. All the estimates for storage coefficient from the injection tests are small enough to suggest that the aquifer is confined below $1,473 \mathrm{ft}$.

\section{AQUIFER TEST}

An aquifer test was made to determine properties farther from the well bore than the area affected by the injection tests. The aquifer test, September 27-28, 1988 , followed completion of the injection tests. During the injection tests, the bottom part of the well (below 2,605 $\mathrm{ft}$ ) was bridged or filled with debris that was not removed prior to the pumping test. The thickness of the test interval was $1,132 \mathrm{ft}$ (from the bottom of the casing at $1,473 \mathrm{ft}$ to the top of the bridge at 2,605 $\mathrm{ft}$ ). The well was pumped at a rate of $169 \mathrm{gal} / \mathrm{min}$ for 31 hours. Drawdown was $78 \mathrm{ft}$. The pump and well during the test are shown in figure 2. Results of the aquifer-test analyses are shown in table 6 .

\section{Analytical Methods}

Estimates of storage coefficient from the injection tests range from $2.1 \times 10^{-5}$ to $3.8 \times 10^{-3}$ and are in the range for confined aquifers. Also, the largest transmissivity from the injection tests, $25 \mathrm{ft}^{2} / \mathrm{d}$, was from interval $\mathrm{D}$, from 1,934 to $2,134 \mathrm{ft}$, and indicates drawdown during pumping would be controlled by such a layer. Interval $\mathrm{D}$ is considered to be confined because it lies below a basalt layer that appears to be a confining unit on the basis of temperature logs and the tracer test. However, the uppermost section of the open part of the well is approximately $18 \mathrm{ft}$ below the water table. During pumping, the water level in the well dropped $60 \mathrm{ft}$ below the cased interval of the well, so that the upper part of the aquifer was dewatered, not just depressured. Thus, the response to pumping indicates a combination of confined and unconfined systems.

The shape of the time-drawdown curve may be interpreted as either a response to delayed yield (unconfined aquifer), or a response to a leaky confining unit (confined aquifer). The pumping-test data were analyzed for both confined and unconfined conditions 
Table 5. Summary of injection-test analyses for Pahute Mesa-3 test well, Nye County, Nevada

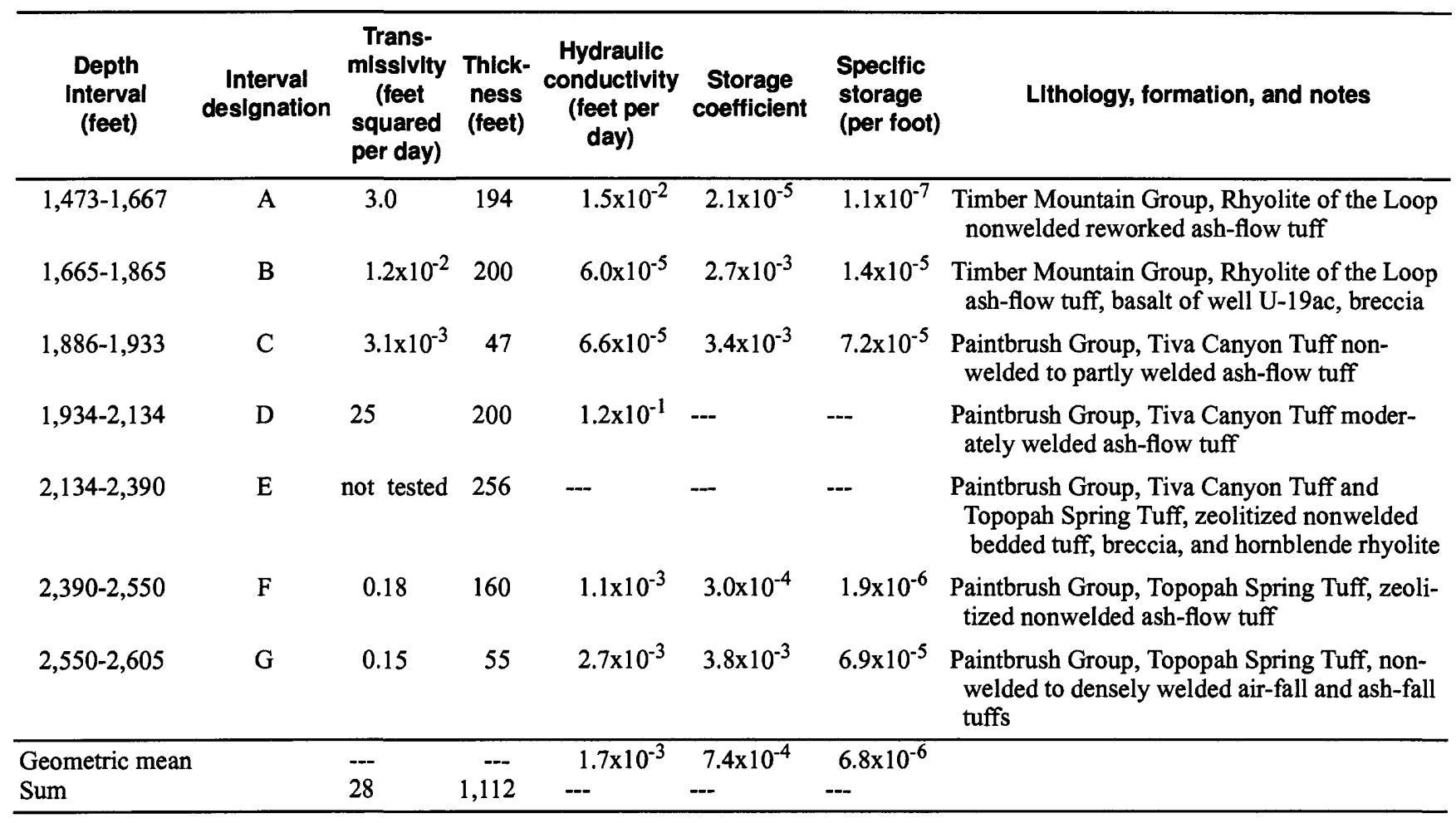

during pumping and recovery to determine hydraulic properties. In addition, bore-hole storage effects were considered because the well bore has a large diameter (17 in.) just below the casing due to fluid-flow effects during the construction of the well.

\section{Unconfined Radial Flow}

Analysis of the data, assuming that the aquifer is unconfined and flow is radial towards the test well, is based on the theoretical work of Boulton (1963) for delayed yield. The data are plotted on logarithmic paper as drawdown, $s$, against time, $t$. The graphs are matched against plots of $W(u)$, the well function, and $1 / u$ for different values of $r / B$, where,

$r$ is the well radius in the producing zone, in feet; $B$ is a coefficient that relates well-bore storage to aquifer storage.

$W(u)$ is defined,

$$
W(u)=\frac{4 \pi T s}{Q},
$$

where,

$T$ is the transmissivity, in square feet per day; $s$ is the drawdown, in feet; and

$Q$ is the pump discharge, in cubic feet per day.
The function $u$ (dimensionless) is defined,

$$
u=\frac{r^{2} S}{4 T t},
$$

where,

$t$ is the time elapsed since pumping began, in minutes, and

$S$ is storage coefficient, dimensionless.

Transmissivity is then computed from the data at the matchpoint from,

$$
T=\frac{W(u) Q}{4 \pi s},
$$

and hydraulic conductivity, $K$, is computed as in equation (4).

To accommodate well-bore storage, the data are plotted on logarithmic paper as $s / Q$ where $Q$ is the discharge derived only from the aquifer and not from well-bore storage, against $t / r^{2}$ where $r$ is the well radius and may vary for each increment of pumping time and drawdown measured. The above equations are used in computations of transmissivity and hydraulic conductivity.

Type curves for delayed yield can be matched to either the early part of the time-drawdown data, the late part, or preferably both, and the difference used to estimate vertical hydraulic conductivity. For such an 
Table 6. Summary of aquifer-test analyses for Pahute Mesa-3 test well, Nye County, Nevada

\begin{tabular}{|c|c|c|c|c|}
\hline Analysis & $\begin{array}{l}\text { Depth } \\
\text { Interval } \\
\text { (feet) }\end{array}$ & $\begin{array}{l}\text { Thickness } \\
\text { (feet) }\end{array}$ & $\begin{array}{l}\text { Transmissivity } \\
\text { (feet squared } \\
\text { per day) }\end{array}$ & $\begin{array}{l}\text { Hydraulic } \\
\text { conductivlty } \\
\text { (feet per } \\
\text { day) }\end{array}$ \\
\hline \multicolumn{5}{|c|}{ Unconfined Aquifer } \\
\hline $\begin{array}{l}\text { Pumping }^{1} \\
\text { Recovery } \\
\text { Pumping, well-bore storage effects removed } \\
\text { Recovery, well-bore storage effects removed }\end{array}$ & $\begin{array}{l}1,473-2,605 \\
\text { do. } \\
\text { do. } \\
\text { do. }\end{array}$ & $\begin{array}{r}1,132 \\
\text { do. } \\
\text { do. } \\
\text { do. }\end{array}$ & $\begin{array}{l}70 \\
55 \\
51 \\
38\end{array}$ & $\begin{array}{l}6.2 \times 10^{-2} \\
4.9 \times 10^{-2} \\
4.5 \times 10^{-2} \\
3.4 \times 10^{-2}\end{array}$ \\
\hline \multicolumn{5}{|c|}{ Confined Aquifer } \\
\hline $\begin{array}{l}\text { Pumping }{ }^{2} \\
\text { Recovery }^{2} \\
\text { Pumping well-bore storage effects removed } \\
\text { Recover, well-bore storage effects removed }\end{array}$ & $\begin{array}{l}\text { do. } \\
\text { do. } \\
\text { do. } \\
\text { do. }\end{array}$ & $\begin{array}{l}\text { do. } \\
\text { do. } \\
\text { do. } \\
\text { do. }\end{array}$ & $\begin{array}{r}76 \\
52 \\
370 \\
360\end{array}$ & $\begin{array}{l}6.7 \times 10^{-2} \\
4.6 \times 10^{-2} \\
0.33 \\
0.32\end{array}$ \\
\hline $\begin{array}{l}\text { Pumping, well-bore storage effects removed }{ }^{4} \\
\text { Recovery, well-bore storage effects removed }{ }^{4} \\
\text { Specific capacity }{ }^{5}\end{array}$ & $\begin{array}{l}\text { do. } \\
\text { do. } \\
\text { do. }\end{array}$ & $\begin{array}{l}\text { do. } \\
\text { do. } \\
\text { do. }\end{array}$ & $\begin{array}{l}410 \\
840 \\
640\end{array}$ & $\begin{array}{l}0.36 \\
0.74 \\
0.57\end{array}$ \\
\hline $\begin{array}{l}1 \text { Boulton, 1963, and Neuman, } 1975 \\
2 \text { Hantush and Jacob, } 1955 \\
{ }^{3} \text { Papadopulos and Cooper, } 1967\end{array}$ & \multicolumn{4}{|c|}{$\begin{array}{l}{ }^{4} \text { Cooper and Jacob, } 1946 \\
{ }^{5} \text { Lohman, } 1972\end{array}$} \\
\hline
\end{tabular}

analysis, Neuman (1975, eqn. 23) shows that a new term, $\beta$, is included. $\beta$ may be calculated from $r / B$ of Boulton (1963) as:

$$
\frac{\left(\frac{r}{B}\right)^{2}}{\beta}=3.063-0.567 \log \beta
$$

where $\beta$ is a proportionality constant between hydraulic conductivity and the part of the aquifer affected by pumping. The type curves of Neuman (1975) are in other respects similar to those of Boulton, although the theories differ in their treatment of the phreatic surface. The data collected during this test did not indicate late drawdown that would allow such an interpretation, and so vertical hydraulic conductivity is not discussed here.

Analysis of aquifer recovery following pumping is a good check on the aquifer response during the aquifer test, particularly if the pumping rate varied during the test, or if flow in the well bore was turbulent during pumping (Todd, 1976, p. 132). If the well-aquifer system achieved a steady-state condition during pumping, the Houpert-Pouchan assumption may be invoked (de Marsily, 1986, p. 177). When this condition is met, the recovery curve is plotted as residual drawdown and interpreted as a drawdown curve. The test results from PM-3 meet this Houpert-Pouchan assumption, as drawdown changed little between the $2 \mathrm{~d}$ and 31 st (final) hour of pumping.

\section{Confined Radial Flow}

Analysis of the data assuming that the aquifer is confined and flow is radial was based on the theoretical work of several authors. Hantush and Jacob (1955) derived an analysis for leaky confined aquifers. The data are plotted on logarithmic paper as drawdown, $s$, against time, $t$. The graphs are matched against plots of $L(u, v)$, the well function, against $1 / u$ for different values of $v$ on a logarithmic graph. $L(u, v)$ (dimensionless) is defined in the equation:

$$
L(u, v)=\frac{4 \pi T s}{Q},
$$

where $v$ is a coefficient relating horizontal to vertical hydraulic conductivity. The function $u$ (dimensionless) is defined as in equation (7).

Transmissivity is then computed from the matchpoint from,

$$
T=\frac{L(u, v) Q}{4 \pi s} .
$$

Hydraulic conductivity, $K$, is computed as in equation (4).

An analysis to accommodate well-bore storage was proposed by Papadopulos and Cooper (1967) for confined aquifers. The analysis assumes two-dimensional radial flow from the formation into the test well. The data are plotted on logarithmic paper as drawdown, $s$, against time, $t$. Type curves are generated by 
plotting $F(u, \alpha)$, the well function, against $1 / u$ for different values of $\alpha$ on a logarithmic graph. $F(u, \alpha)$ is defined,

$$
F(u, \alpha)=\frac{4 \pi T s}{Q},
$$

where the function $u$ is defined as in equation (7) and the value of $\alpha$ (dimensionless) is defined,

$$
\alpha=\frac{S r_{w}^{2}}{r_{c}^{2}},
$$

where $r_{c}$ is the well radius where the water level is drawing down and $r_{w}$ is the well radius within the aquifer. Values for $F(u, \alpha)$ are presented by Papadopulos and Cooper (1967) for different combinations of $u$ and $\alpha$.

Transmissivity is calculated from,

$$
T=\frac{F(u, \alpha) Q}{4 \pi s},
$$

and hydraulic conductivity is calculated as in equation (4).

Aquifer recovery after pumping ceased may also be analyzed by these two methods following the assumptions of Houpert-Pouchan (de Marsily, 1986, p. 177). The recovery curve is plotted as residual drawdown and interpreted as a drawdown curve.

The straight-line method of Cooper and Jacob (1946) also may be used to estimate well-bore effects in a confined aquifer and, in addition, yield insight into barriers and changes in conditions at some distance from the well. The method is not valid for short tests, when $u \leq 0.01$, but is generally valid for later periods. For well-bore storage, data are plotted on semilog paper as $s / Q$ against $t / r^{2}$. Transmissivity is computed from:

$$
T=\frac{2.30\left[\log \Delta\left(\frac{t}{r^{2}}\right)\right]}{4 \pi \Delta\left(\frac{s}{Q}\right)},
$$

where $\Delta\left(t / r^{2}\right)$ is usually taken as one log cycle so that $\log \Delta\left(t / r^{2}\right)$ equals 1 .

For analysis of recovery using the Cooper and Jacob (1946) straight-line method and including wellbore storage effects, the Houpert-Pouchan assumption is not used. Instead, the data are plotted as $s / Q$ against $t / t^{\prime}\left(r^{2}\right)$, where $t$ is time since pumping began and $t^{\prime}$ is time since pumping stopped.

$$
T=\frac{2.30\left[\log \Delta\left(\frac{t}{t^{\prime}\left(r^{2}\right)}\right)\right]}{4 \pi \Delta\left(\frac{s}{Q}\right)},
$$

\section{Specific Capacity}

Specific-capacity tests are less accurate than aquifer tests because they utilize only the endpoint data. They are based on the assumption of two-dimensional radial flow in a confined aquifer where pumping has continued long enough that steady-state drawdown is reached. Specific capacity is calculated according to the asymptotic method of Cooper and Jacob (1946) as shown in Lohman $(1972$, p. 52). The specific-capacity analysis is included because it is a common method, and other data with which the results of this test will be compared generally are available only from specificcapacity tests.

Specific capacity is calculated from successive iterations of the equation:

$$
T=\left(\frac{Q}{4 \pi s}\right) \ln 2.25\left(\frac{T t}{r^{2} s}\right),
$$

where $T$ on the right side of the equation is initially estimated as some likely value $\left(1,000 \mathrm{ft}^{2} / \mathrm{d}\right)$ and then replaced by the calculated value of $T$ for three or four iterations until both $T$ 's match. An order of magnitude estimate of specific storage also is required for the successful use of this method. $K$ is calculated as shown above (eqn. 4).

\section{Test Conditions}

The aquifer test was made about 2 weeks after the test well had been completed. A submersible pump with a $180 \mathrm{gal} / \mathrm{min}$ discharge capacity was installed with a 2.875 in. pump column at a depth of $1,758 \mathrm{ft}$. A 2.375-in. diameter open-ended monitor line was attached to the pump column. The orifice was $10 \mathrm{ft}$ below the pump intake to allow access to the lower part of the test well during pumping. The well was developed with two pumping and recovery periods prior to the aquifer test.

The aquifer test began at 1600 hours on September 26 and ended at 2300 hours on September 27 . Water levels were measured during the first 18 hours of the test by means of a pressure transducer set at $1,740 \mathrm{ft}$. 
Recording and printing equipment at the surface provided continuous drawdown data. After 18 hours, the transducer was removed from the well and the temperature and tracejector probes emplaced for the borehole-flow survey. After the borehole-flow survey, the transducer was returned to the well at a depth of $1,700 \mathrm{ft}$ and allowed to stabilize to the ambient water temperature. Water-level recovery was measured for $91 / 2$ hours after the pump was turned off, until the water level returned to the prepumping level of $1,455 \mathrm{ft}$.

Pump discharge was monitored during the test by manual observations of a totalizing flow meter set in the pump discharge line. Discharge volumes for brief periods were recorded throughout the test and compared to totalized volumes for longer periods. The average pump discharge was $169 \mathrm{gal} / \mathrm{min}$ for the duration of the test, with a total volume of 314,000 gal pumped.

\section{Analysis of Results}

Figure 9 shows time-drawdown plots of representative data for the aquifer test. Drawdown was $78 \mathrm{ft}$ at the completion of the 1,860-minute aquifer test and drawdown recovered to prepumping levels within 100 minutes after the pump was turned off. The shape of the recovery curve was similar to that of the drawdown curve.

\section{Unconfined Conditions}

Comparison of the aquifer-test drawdown data to curves for unconfined flow with delayed yield (fig. 9) (Boulton, 1963; Neuman, 1975) yielded a matchpoint of $1 / u$ equal to $10, W(u)$ equal to $1.0, t$ equal to $16 \mathrm{~min}$ utes, and $s$ equal to $37 \mathrm{ft}$ for $r / B$ of $0.4(\beta=0.04)$. Transmissivity was calculated to be $70 \mathrm{ft}^{2} / \mathrm{d}$ and hydraulic conductivity was $6.2 \times 10^{-2} \mathrm{ft} / \mathrm{d}$. The recovery curve
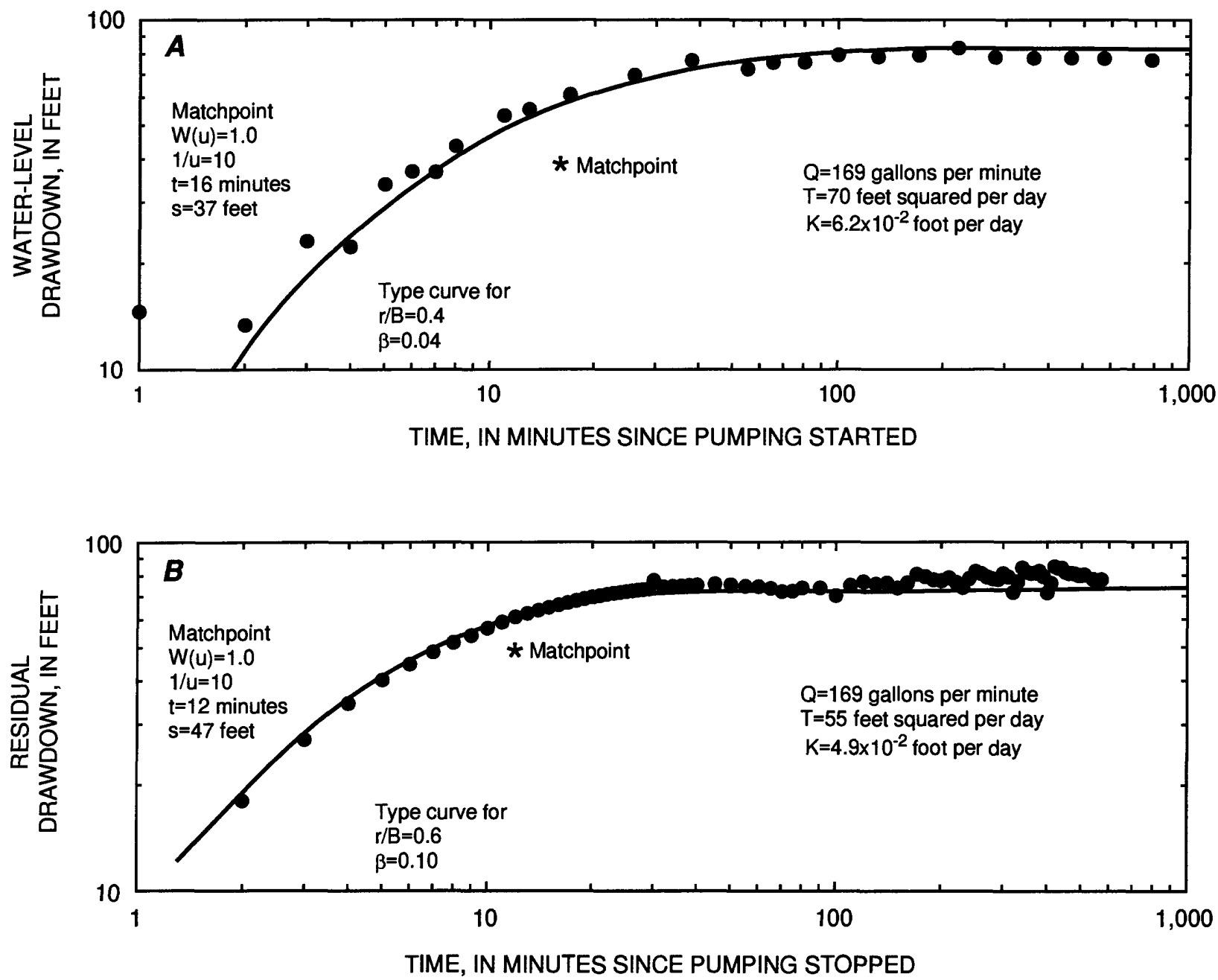

Figure 9. Analysis of drawdown for an unconfined aquifer under the assumption of delayed yield during $A$, pumping and $B$, recovery at Pahute Mesa-3 test well, Nye County, Nevada. Abbreviations: W(u), the well function of $u ; u$, the argument of the well function; $t$, time; $s$, drawdown in the well; $Q$, pump discharge; $T$, transmissivity; $K$, hydraulic conductivity; $r$, radius of the well; $B$, leakage factor. 
(fig. 9B) yielded a matchpoint of $1 / u$ of $10, W(u)$ equal to $1.0, t$ equal to 12 minutes, and $s$ equal to $47 \mathrm{ft}$ for $r / B$ equal to $0.6(\beta=0.10)$. Transmissivity was calculated to be $55 \mathrm{ft}^{2} / \mathrm{d}$ and hydraulic conductivity was $4.9 \times 10^{-2}$ $\mathrm{ft} / \mathrm{d}$.

Analysis of the aquifer-test data with well-bore storage taken into account is shown in figure 10. The pumping data yielded a matchpoint of $1 / u$ equal to 1.0 , $W(u)$ equal to $1.0, t / r^{2}$ equal to $2.4 \mathrm{~min} / \mathrm{ft}^{2}$, and $s / Q$ equal to $0.3 \mathrm{ft} / \mathrm{gal} / \mathrm{min}$ for $r / B$ of $0.6(\beta=0.1)$. Transmissivity was calculated to be $51 \mathrm{ft}^{2} / \mathrm{d}$ and hydraulic conductivity was $4.5 \times 10^{-2} \mathrm{ft} / \mathrm{d}$. The recovery curve (fig. $10 \mathrm{~B})$ yielded a matchpoint of $1 / u$ of $1, W(u)$ equal to 1 , $t / r^{2}$ equal to $6.5 \mathrm{~min} / \mathrm{ft}^{2}$, and $s / Q$ equal to $0.4 \mathrm{ft} / \mathrm{gal} / \mathrm{min}$ for $r / B$ equal to $0.8(\beta=0.18)$. Transmissivity was calculated to be $38 \mathrm{ft}^{2} / \mathrm{d}$ and hydraulic conductivity was $3.4 \times 10^{-2} \mathrm{ft} / \mathrm{d}$.

\section{Confined Conditions}

Analysis of the aquifer-test data assuming leaky confined conditions (Hantush and Jacob, 1955) yielded a matchpoint with $L(u, v)$ equal to $1.0,1 / u$ equal to $10, t$ equal to $13 \mathrm{~min}$, and $s$ equal to $34 \mathrm{ft}$, for a $v$ of 0.2 (fig. 11A). Transmissivity was calculated to be $76 \mathrm{ft}^{2} / \mathrm{d}$ and hydraulic conductivity was $6.7 \times 10^{-2} \mathrm{ft} / \mathrm{d}$. The recovery curve (fig. $11 B$ ) yielded a matchpoint with $L(u, v)$ equal to $1,1 / u$ equal to $10, t$ equal to $14 \mathrm{~min}$, and $s$ equal to $50 \mathrm{ft}$, for a $v$ of 0.3 . Transmissivity was calculated to be $52 \mathrm{ft}^{2} / \mathrm{d}$ and hydraulic conductivity was $4.6 \times 10^{-2} \mathrm{ft} / \mathrm{d}$.

Analysis of the aquifer-test data for well-bore storage assuming confined conditions (Papadopulos and Cooper, 1967) yielded a matchpoint with $F(u, \alpha)$ equal to $10,1 / u$ equal to $10,000, t$ equal to 8.5 minutes, and $s$ equal to $70 \mathrm{ft}$, for an $\alpha$ of $10^{-3}$ (fig. 12A). Transmissivity was calculated to be $370 \mathrm{ft}^{2} / \mathrm{d}$, hydraulic conductivity was calculated to be $0.33 \mathrm{ft} / \mathrm{d}$. The recovery curve (fig. $12 B$ ) yielded a matchpoint of $1 / u$ equal to $10,000, F(u, \alpha)$ equal to $10, t$ equal to 5 minutes, and $s$ equal to $72 \mathrm{ft}$, for an $\alpha$ of $10^{-3}$. Transmissivity was calculated to be $360 \mathrm{ft}^{2} / \mathrm{d}$ and hydraulic conductivity was $0.32 \mathrm{ft} / \mathrm{d}$.

The straight-line analysis of pumping (Cooper and Jacob, 1946) yielded $\Delta s / Q$ equal to 0.085 $\mathrm{ft} / \mathrm{gal} / \mathrm{min} / \log$ cycle of $t / r^{2}$ (fig. 13A). Radial transmissivity was calculated to be $410 \mathrm{ft}^{2} / \mathrm{d}$ and hydraulic conductivity was $0.36 \mathrm{ft} / \mathrm{d}$. The recovery analysis (fig. $13 B$ ) yielded $\Delta s / Q$ of $0.042 \mathrm{ft} / \mathrm{gal} / \mathrm{min} / \mathrm{log}$ cycle of $t / t^{\prime} r^{2}$. Transmissivity was $840 \mathrm{ft}^{2} / \mathrm{d}$ and hydraulic conductivity was $0.74 \mathrm{ft} / \mathrm{d}$. Because the plots do not conform well to the theoretical analysis, these estimates of transmissivity and hydraulic conductivity are considered less accurate than the above tests.

The specific capacity test yielded an estimate of transmissivity of $640 \mathrm{ft}^{2} / \mathrm{d}$ and a hydraulic conductivity of $0.57 \mathrm{ft} / \mathrm{d}$, assuming a storage coefficient of 0.0007 (geometric mean of injection test results). The analysis of specific capacity is based on only the endpoint measurement and, therefore, is the least accurate of the three pumping-test analyses.

\section{Discussion}

The pumping-test results do not lead to a singular conclusion about aquifer properties. Transmissivities calculated using the assumption that the aquifer is unconfined with delayed yield ranges from 38 to 70 $\mathrm{ft}^{2} / \mathrm{d}$. These are slightly larger than the sum of the injection tests, $28 \mathrm{ft}^{2} / \mathrm{d}$. Hydraulic conductivity ranges from $3.4 \times 10^{-2}$ to $6.2 \times 10^{-2} \mathrm{ft} / \mathrm{d}$, whereas the geometric mean of the injection tests is $1.7 \times 10^{-3}$. Corrections for well-bore storage do not significantly affect the transmissivity, and hydraulic-conductivity estimates under the assumption of unconfined conditions.

Transmissivity calculated under the assumption that the aquifer is confined by a leaky layer yields estimates from 52 to $840 \mathrm{ft}^{2} / \mathrm{d}$. The correction for wellbore storage has a significant effect. The range of transmissivity for data corrected for well-bore storage is from 360 to $840 \mathrm{ft}^{2} / \mathrm{d}$, approximately an order of magnitude larger than the sum of the injection-test estimates. Hydraulic conductivity is 0.32 to $0.74 \mathrm{ft} / \mathrm{d}$, approximately two orders of magnitude larger than the geometric mean of the injection-test estimates.

Several possible reasons why the injection test results do not agree with the aquifer test results include: (1) Injection tests were made shortly after completion of the well, prior to development, and may have been affected by the presence of drilling fluids. The larger density and viscosity of drilling fluids would reduce the rate of inflow of injected water and lead to lower estimates of transmissivity. The aquifer test was run about 2 weeks later, following a period of development.

(2) The injection tests measure a much smaller volume of aquifer than the aquifer test. In a fractured medium, some fractures that are near the well bore, but do not intersect it, will only affect tests that include a large volume surrounding the well. Hence, the longer aquifer test may produce a larger estimate of transmissivity. (3) Sidewall coring was done in the well after the injection tests but before the aquifer test. The affect on 

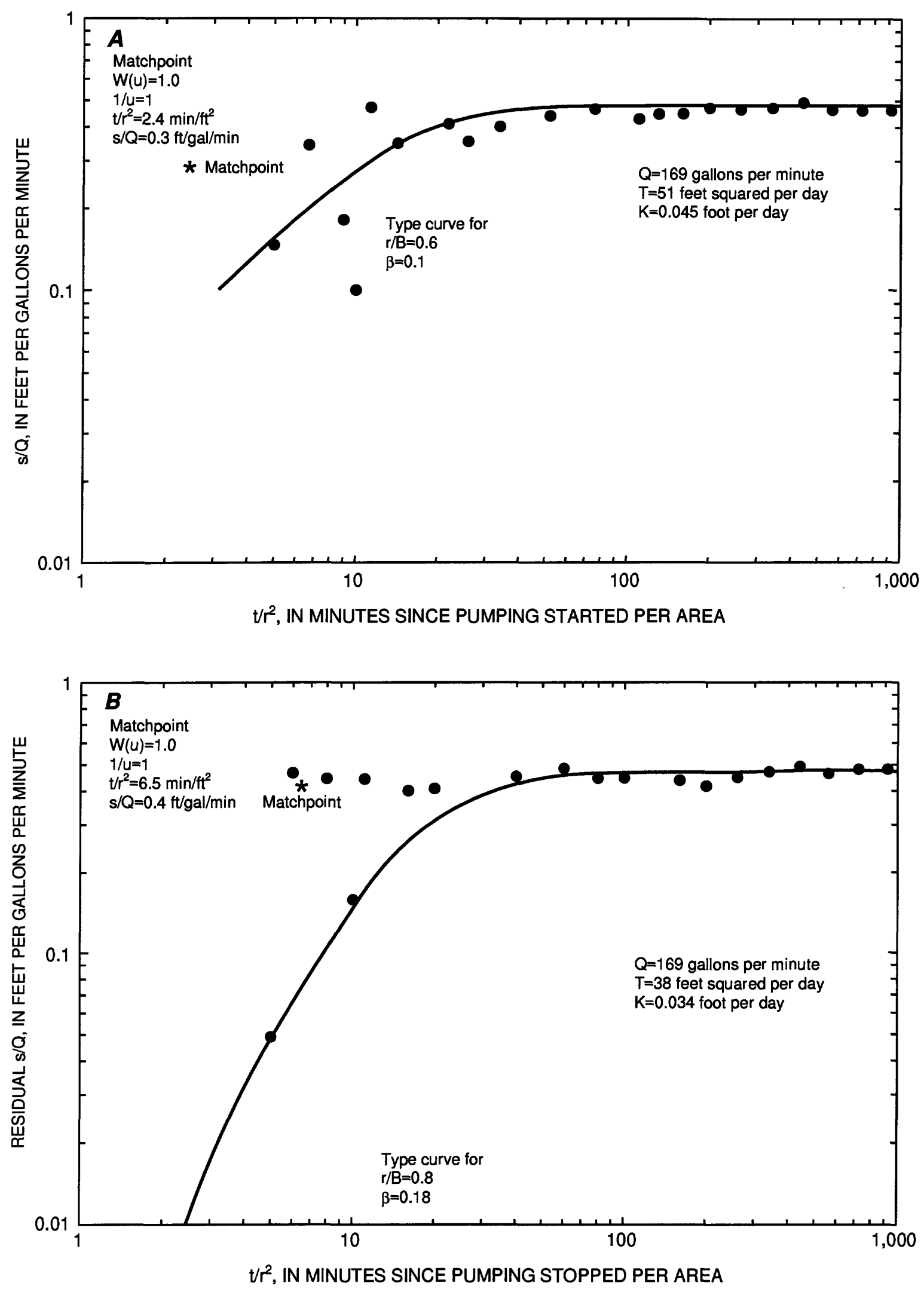

Figure 10. Analysis of drawdown for an unconfined aquifer under the assumption of delayed yield and correction for well-bore storage during $A$, pumping and $B$, recovery at Pahute Mesa-3 test well, Nye County, Nevada. Abbreviations: $W(u)$, the well function of $u$; $u$, the argument of the well function; $t$, time; $s$, drawdown in the well; $Q$, pump discharge; $T$, transmissivity; $K$, hydraulic conductivity; $r$, radius of the well; $B$, leakage factor. 


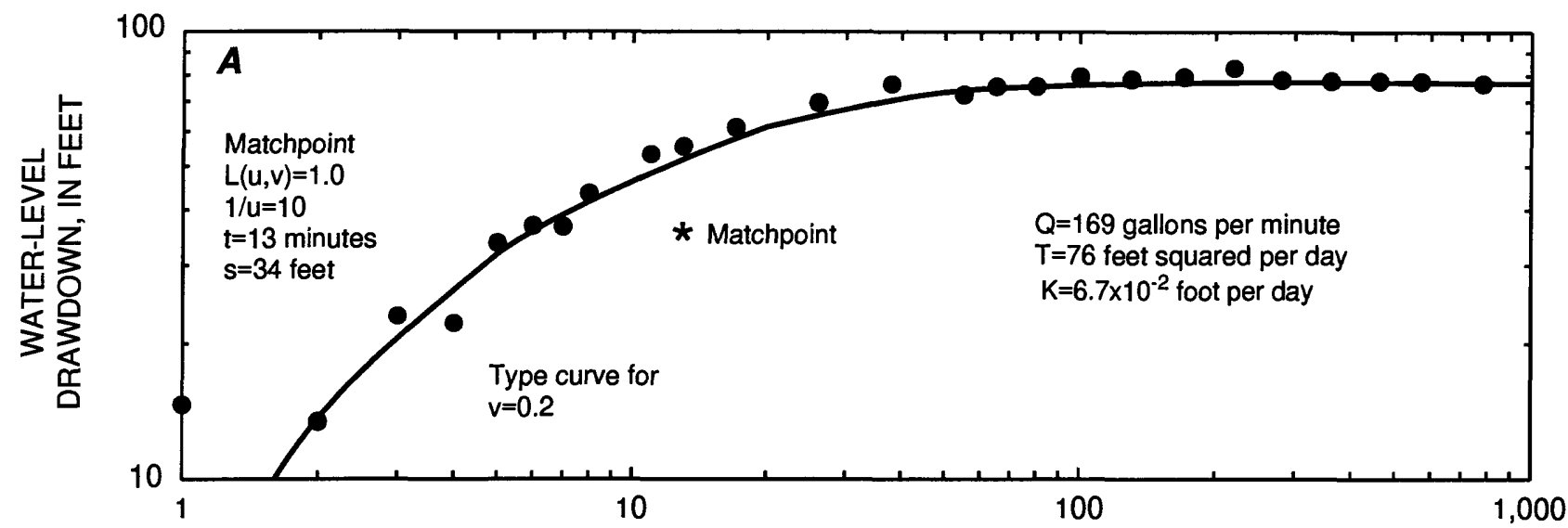

TIME, IN MINUTES SINCE PUMPING STARTED

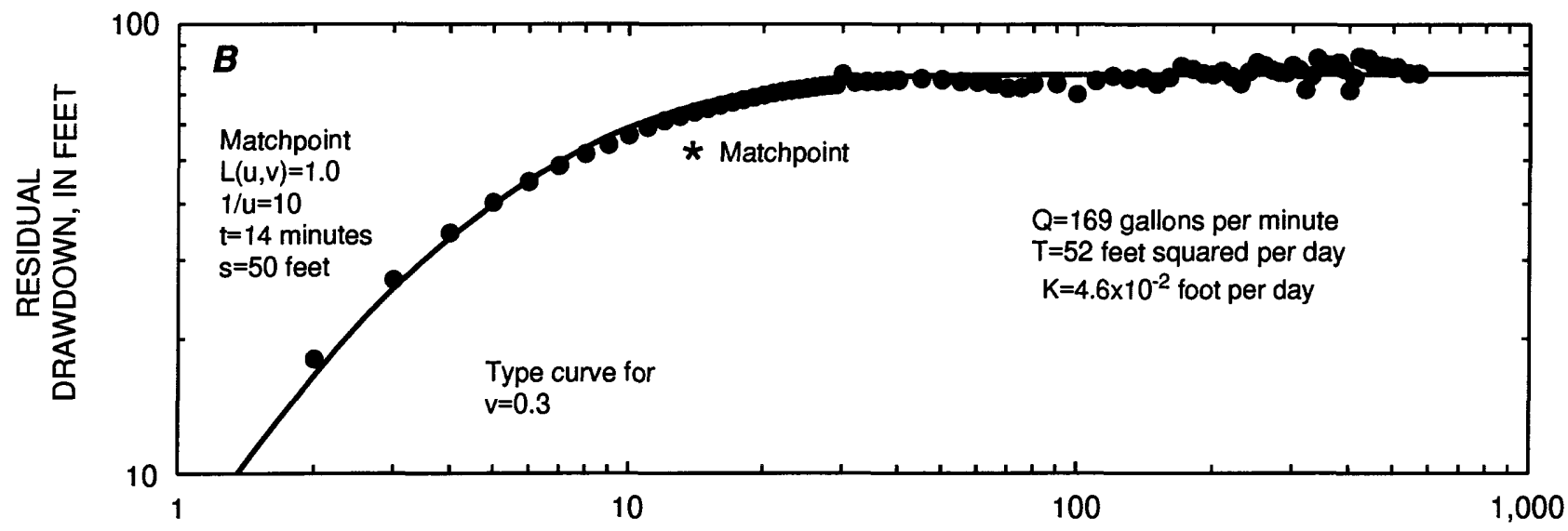

TIME, IN MINUTES SINCE PUMPING STOPPED

Figure 11. Analysis of drawdown for a leaky confined aquifer during $A$, pumping and $B$, recovery at Pahute Mesa-3 test well, Nye County, Nevada. Abbreviations: $L(u, v)$, the well function of $u$ for a leaky confined aquifer; $u$, the argument of the well function; $v$, the coefficient relating horizontal to vertical hydraulic conductivity; $t$, time; $s$, drawdown in the well; $Q$, pump discharge; T, transmissivity; $K$, hydraulic conductivity.

hydraulic conductivity of setting off numerous small charges in the well, and removal of small cores is unknown. Such procedures do increase the surface area of the well bore, could increase fractures, and may lead to increased hydraulic conductivity.

The response of the unconfined part of the aquifer cannot be separated from the response of the confined part of the aquifer in the analysis of drawdown. The most transmissive section of the aquifer, interval D, however, probably is the major control on drawdown during the aquifer test. Interval D remained confined throughout the aquifer test. On the basis of this assumption, the average transmissivity estimated using the leaky confined theory with well-bore storage effects removed, $360 \mathrm{ft}^{2} / \mathrm{d}$, is the best estimate for the depth interval from 1,473 to $2,605 \mathrm{ft}$ under the conditions of this test, and the best estimate of hydraulic conductivity is $0.32 \mathrm{ft} / \mathrm{d}$.

\section{WATER LEVELS}

\section{Water-Level Altitudes at the Test Well}

Water levels at PM-3 for September 1988 to June 1990 are shown in fig. 14. Water-level altitude was computed by subtracting the depth to water from the altitude of the measuring point, which is $5,823 \mathrm{ft}$ above sea level. The measuring point is the rim of the casing at land surface. A contractor measured water levels from September 9 to October 10, 1988, using a fluid- 


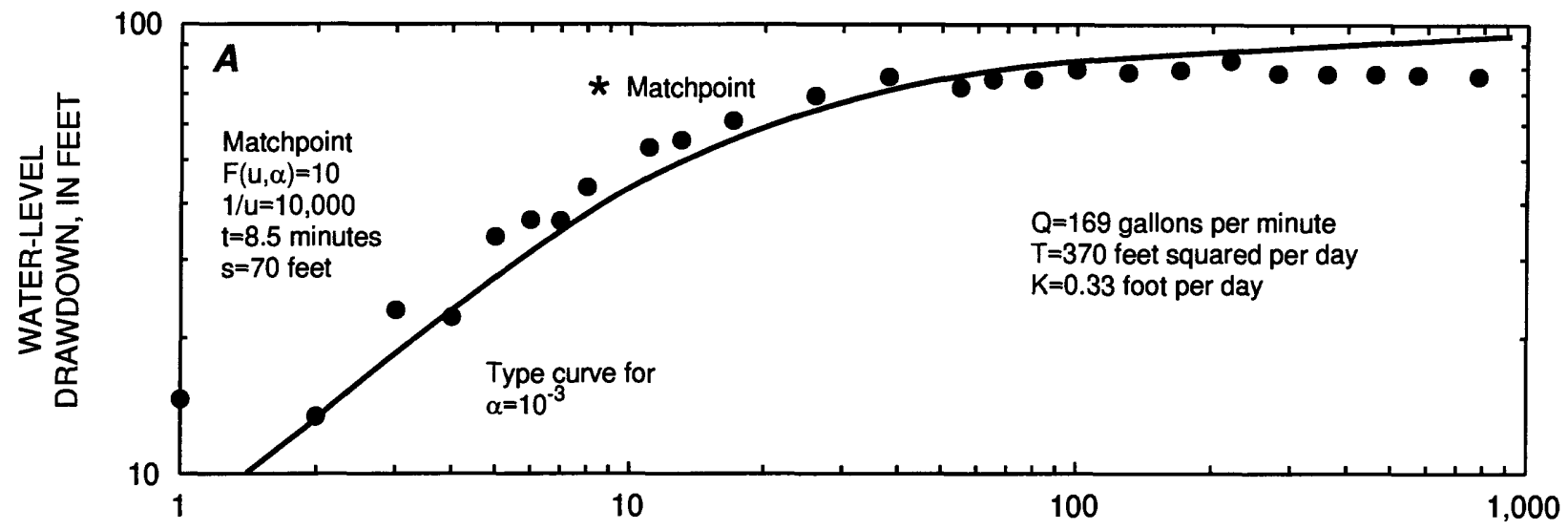

TIME, IN MINUTES SINCE PUMPING STARTED

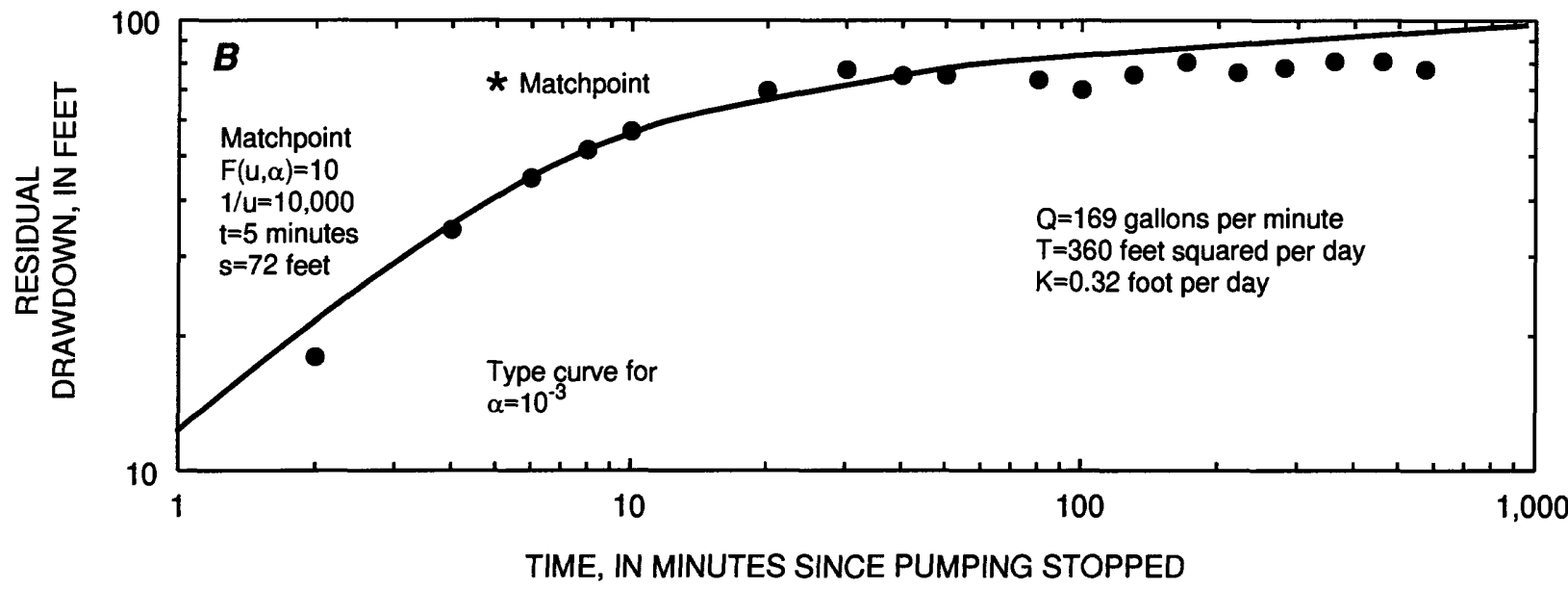

Figure 12. Analysis of drawdown for a leaky confined aquifer under the assumption of delayed yield and well-bore storage during $A$, pumping and $B$, recovery at Pahute Mesa-3 test well, Nye County, Nevada. Abbreviations: $F(u, \alpha)$, the well function of $u$ for a leaky confined aquifer with delayed yield; $u$, the argument of the well function; $\alpha$, the coefficient relating horizontal to vertical hydraulic conductivity; $t$, time; s, drawdown in the well; $Q$, pump discharge; $T$, transmissivity; $\mathrm{K}$, hydraulic conductivity.

density geophysical instrument or other geophysical logs. The USGS measured water levels from December 1988 to June 1990 with an electric tape mounted on a truck hoist unit. Water-level measurements made during the aquifer and injection tests are not shown on figure 14.

Water-levels changed slightly when the test well was deepened from 1,647 to $3,019 \mathrm{ft}$ in 1988. During the first geophysical logging phase, when the test well was $1,647 \mathrm{ft}$ deep, water-level altitudes ranged from 4,367 to $4,368 \mathrm{ft}$. During the second logging phase, when the test well was $3,019 \mathrm{ft}$ deep, water-level altitudes ranged from 4,366 to $4,367 \mathrm{ft}$.

Water-level altitudes during the 2-year period from November 1988 to June 1990, after drilling and testing was completed, ranged from 4,362 to $4,366 \mathrm{ft}$.
The water-level-altitude range is typical. Robison and others (1988) measured 4-ft water-level fluctuations during several months in the Yucca Mountain area, $30 \mathrm{mi}$ to the south. Water levels were lowest in December 1988 and September 1989, suggesting a seasonal effect.

\section{Ground-Water Gradient}

Blankennagel and Weir (1973, pl. 1) mapped water-level altitudes in and near Silent Canyon caldera to the north and east of PM-3. Their work shows that water levels in the area of PM-3 outside of the caldera slope to the southeast and that water levels within the caldera slope to the southwest (fig. 15). Blankennagel and Weir inferred that a hydraulic barrier to flow is 

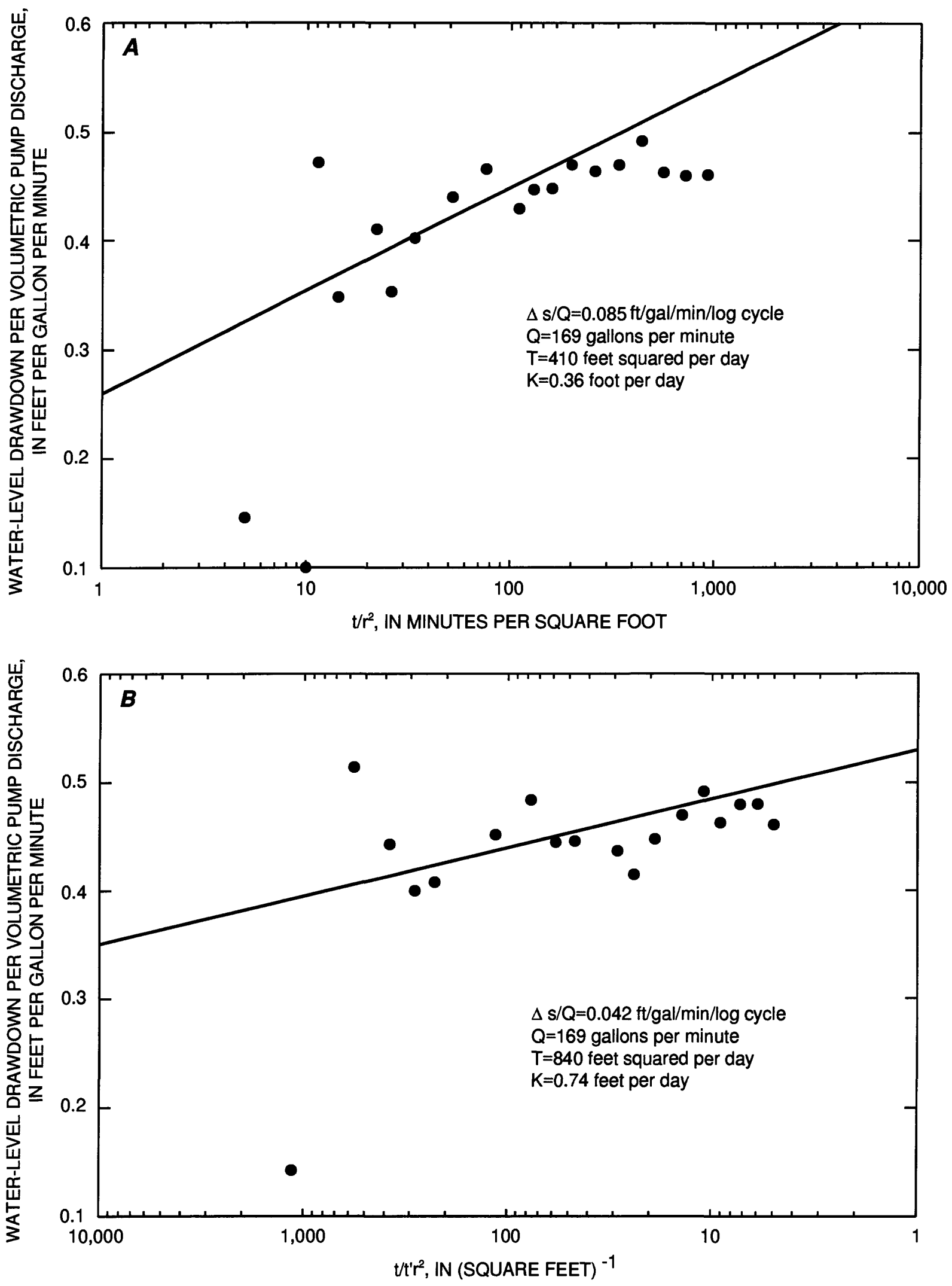

Figure 13. Analysis of drawdown for a confined aquifer under the assumption of delayed yield and correction for well-bore storage during $A$, pumping and $B$, recovery at Pahute Mesa-3 test well, Nye County, Nevada. Abbreviations: $\Delta s$, the change in drawdown since the last time step; $Q$, pump discharge; $T$, Transmissivity; and K, hydraulic conductivity. 


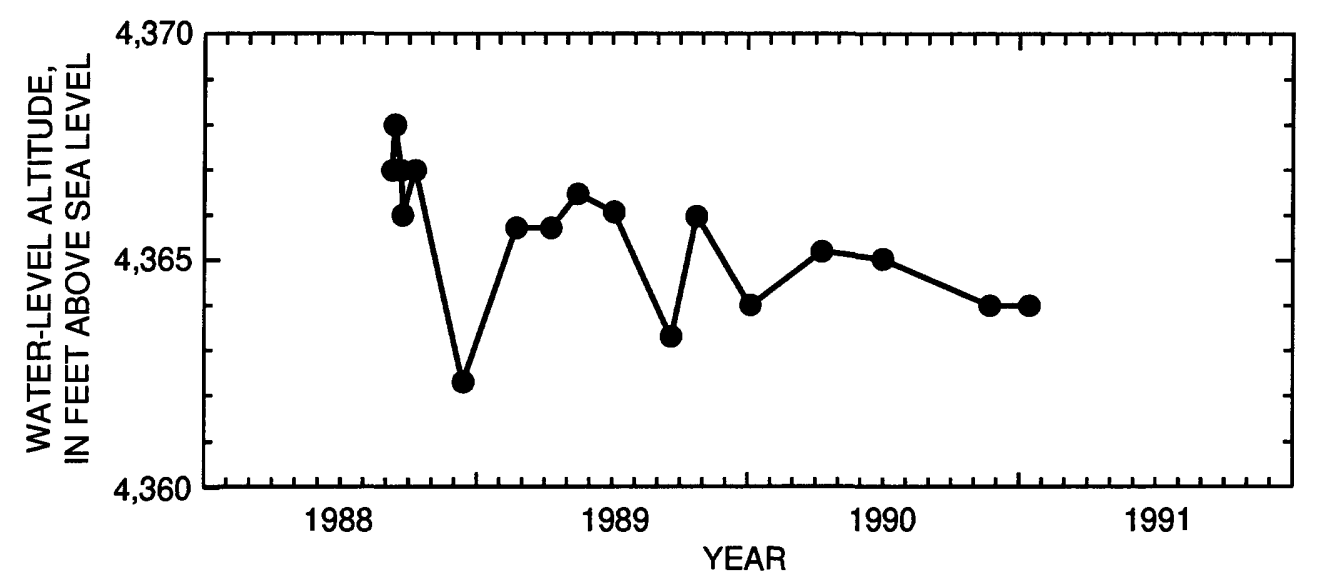

Figure 14. Water-level altitudes in Pahute Mesa-3 test well, Nye County, Nevada

located approximately along the western boundary of the caldera between areas of southeastward and southwestward gradients. The Silent Canyon caldera boundary fault juxtaposes intracaldera rocks with moderate permeabilities against precaldera rocks having lower permeabilities, hence it is not so much a barrier as a boundary that functions as a conduit to transmit fluid.

Contours west of the caldera boundary were based on water levels in only three wells. The water level in PM-3 does not contradict the interpretation of Blankennagel and Weir (1973); however, it does show that inferred positions of the 4,500 and 4,600- $\mathrm{ft}$ contours should be a little closer together to allow for a 4,400-ft contour.

\section{GROUND-WATER QUALITY}

\section{Water Chemistry}

Water-quality parameters analyzed for samples from PM-3 to document water chemistry at the site (table 7). A water sample was collected on October 28 when the test well was pumped to remove fluids introduced during cleaning of the test well on October 21 . The pump intake was set at a depth of $1,655 \mathrm{ft}$ and the test well was pumped for approximately $24 \mathrm{hrs}$ before the sample was collected. Four methods were used by DRI personnel to ascertain that formation water, and not introduced water, was being sampled: (1) intermittent field measurements of temperature, $\mathrm{pH}$, and specific conductance indicated the characteristics of water being discharged had stabilized; (2) bromide, which was used as a tracer at $20 \mathrm{mg} / \mathrm{L}$ in fluids introduced into the test well, was $0.54 \mathrm{mg} / \mathrm{L}$; (3) field measurements of detergent concentration were much lower than in drilling fluid samples; and (4) major cation and anions collected after the aquifer test yielded values similar to those collected after the injection tests.

The water sample was analyzed for dissolved constituents by the USGS water-quality laboratory (table 7). Temperature, $\mathrm{pH}$, and specific conductance were measured in the field by USGS personnel and the results, within the limits of analytical uncertainty, were similar to those collected by DRI personnel. Samples collected for laboratory analysis of major ions by the USGS also yielded results similar to those for samples collected by DRI personnel. DRI personnel also analyzed for stable and unstable isotopes. Water samples collected prior to the injection tests contained too much drilling fluid and formation material to be representative of formation water. A bailed sample taken during the first period of geophysical logging and an air-lifted sample taken from the test well after a weekend shutdown in drilling also contained excessive drilling fluid and were not representative of formation water.

Water from PM-3 is a sodium mixed-anion water. Sodium had the highest concentration, $130 \mathrm{mg} / \mathrm{L}$, and the highest percentage in milliequivalents per liter, 73 percent, of the major cations. Calcium, potassium, and magnesium had concentrations of 36,10 , and $1.5 \mathrm{mg} / \mathrm{L}$ respectively $(23,3$, and 1 percent of the milliequivalents per liter). Bicarbonate had the highest concentration, $150 \mathrm{mg} / \mathrm{L}$, of the major anions. Sulfate, chloride, and fluoride concentrations were 130,98 , and $2.4 \mathrm{mg} / \mathrm{L}$, respectively. Bicarbonate, sulfate, chloride, and fluoride were $31,34,35$, and 0.006 percent in milliequivalents per liter, respectively. 


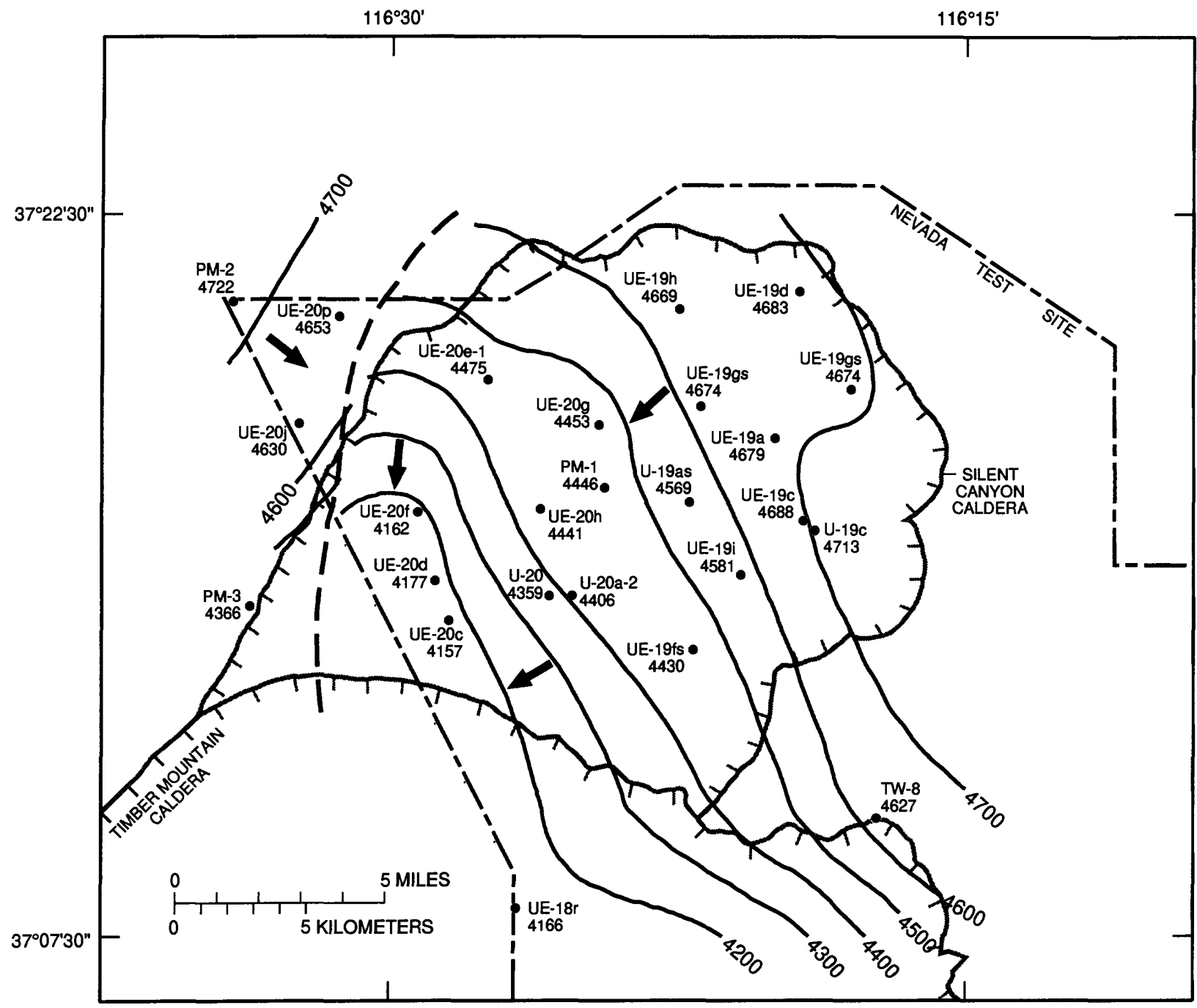

Base prepared by U.S. Geological Survey from

digital data, 1:100,000 1979-89

Universal Transverse Mercator projection

Zone 11

\section{EXPLANATION}

- 4200 - Water-level contour-Shows altitude of water level. Interval 100 feet.

Datum is sea level. Modified from Blankennagel and Weir (1973, plate 1)

- Approximate position of Inferred hydraullc boundary-Modified from Blankennagel and Weir (1973, plate 1)

Caldera boundary-Modified from David A. Sawyer (U.S. Geological Survey written commun., 1991)

General directlon of ground-water flow

- UE-20h Well-Well identifier, and water-level altitude, in feet above sea level
4441

Figure 15. Water-level-altitude contours and ground-water flow direction on Pahute Mesa, Nye County, Nevada. 
Table 7. Water-quality data for Pahute Mesa-3 test well, Nye County, Nevada

[All values are for dissolved concentrations. Abbreviations: $N$, nitrogen; $P$, phosphorus; <, less than; $\mu \mathrm{g} / \mathrm{L}$, micrograms per liter; $\mu \mathrm{s} / \mathrm{cm}$, microsiemens per centimeter; $\mathrm{mg} / \mathrm{L}$, milligrams per liter; ${ }^{\circ} \mathrm{C}$, degrees Celsius]

\begin{tabular}{|c|c|c|c|c|c|c|c|c|c|c|}
\hline $\begin{array}{l}\text { Date } \\
\text { sampled }\end{array}$ & Time & $\begin{array}{c}\text { Temperature } \\
\left({ }^{\circ} \mathrm{C}\right)\end{array}$ & $\mathrm{pH}$ & $\begin{array}{c}\text { Specific } \\
\text { conductance } \\
(\mu \mathrm{s} / \mathrm{cm} \\
\left.\text { at } 25^{\circ} \mathrm{C}\right)\end{array}$ & $\begin{array}{l}\text { Dissolved } \\
\text { solids } \\
\text { (residue } \\
\text { at } 180^{\circ} \mathrm{C} \text { ) }\end{array}$ & $\begin{array}{c}\text { Carbon-13 } \\
\text { (Permil) }^{1}\end{array}$ & $\begin{array}{c}\text { Deuterium } \\
\text { (Permil) }^{1}\end{array}$ & $\begin{array}{l}\text { Oxygen-18 } \\
\text { (Permil) }^{1}\end{array}$ & $\begin{array}{c}\text { Nitrate } \\
\text { plus } \\
\text { nitrite } \\
\text { as } N \\
(\mathrm{mg} / \mathrm{L})\end{array}$ & $\begin{array}{c}\text { Phosphorus } \\
\text { as } \mathrm{P} \\
\text { (mg/L) }\end{array}$ \\
\hline $10-28-88$ & 1030 & 35.5 & 7.60 & 833 & 550 & -116 & -15.0 & -6.7 & 0.390 & 0.010 \\
\hline $\begin{array}{l}\text { Calcium } \\
(\mathrm{mg} / \mathrm{L})\end{array}$ & $\begin{array}{l}\text { Magnesium } \\
(\mathrm{mg} / \mathrm{L})\end{array}$ & $\begin{array}{l}\text { Sodium } \\
(\mathrm{mg} / \mathrm{L})\end{array}$ & $\begin{array}{l}\text { Potassium } \\
\text { (mg/L) }\end{array}$ & $\begin{array}{l}\text { Bicarbonate } \\
(\mathrm{mg} / \mathrm{L})\end{array}$ & $\begin{array}{c}\text { Chloride } \\
\text { (mg/L) }\end{array}$ & $\begin{array}{l}\text { Sulfate } \\
(\mathrm{mg} / \mathrm{L})\end{array}$ & $\begin{array}{c}\text { Fluoride } \\
(\mathrm{mg} / \mathrm{L})\end{array}$ & $\begin{array}{c}\text { Bromide } \\
(\mathrm{mg} / \mathrm{L})\end{array}$ & $\begin{array}{l}\text { Silicon } \\
(\mathrm{mg} / \mathrm{L})\end{array}$ & \\
\hline 36 & 1.5 & 130 & 10 & 150 & 98 & 130 & 2.4 & 0.54 & 63 & \\
\hline $\begin{array}{l}\text { Alumium } \\
(\mu \mathrm{g} / \mathrm{L})\end{array}$ & $\begin{array}{l}\text { Arsenic } \\
(\mu \mathrm{g} / \mathrm{L})\end{array}$ & $\begin{array}{l}\text { Barium } \\
(\mu \mathrm{g} / \mathrm{L})\end{array}$ & $\begin{array}{l}\text { Beryllium } \\
(\mu \mathrm{g} / \mathrm{L})\end{array}$ & $\underset{(\mu \mathrm{g} / \mathrm{L})}{\text { Cadmium }}$ & $\begin{array}{l}\text { Choride } \\
(\mu \mathrm{g} / \mathrm{L})\end{array}$ & $\begin{array}{l}\text { Cobalt } \\
(\mu \mathrm{g} / \mathrm{L})\end{array}$ & $\begin{array}{l}\text { Copper } \\
(\mu \mathrm{g} / \mathrm{L})\end{array}$ & $\begin{array}{c}\text { Iron } \\
(\mu \mathrm{g} / \mathrm{L})\end{array}$ & $\begin{array}{c}\text { Lead } \\
(\mu \mathrm{g} / \mathrm{L})\end{array}$ & \\
\hline$<10$ & 4 & 2 & $<0.5$ & $<1$ & 2 & $<3$ & $<1$ & 60 & $<5$ & \\
\hline $\begin{array}{l}\text { Lithium } \\
(\mu \mathrm{g} / \mathrm{L})\end{array}$ & $\begin{array}{c}\text { Manganese } \\
(\mu \mathrm{g} / \mathrm{L})\end{array}$ & $\begin{array}{l}\text { Mercury } \\
(\mu \mathrm{g} / \mathrm{L})\end{array}$ & $\begin{array}{l}\text { Molybdenum } \\
(\mu \mathrm{g} / \mathrm{L})\end{array}$ & $\begin{array}{l}\text { Nickel } \\
(\mu \mathrm{g} / \mathrm{L})\end{array}$ & $\begin{array}{l}\text { Selenium } \\
(\mu \mathrm{g} / \mathrm{L})\end{array}$ & $\begin{array}{l}\text { Silver } \\
(\mu \mathrm{g} / \mathrm{L})\end{array}$ & $\begin{array}{c}\text { Strontium } \\
(\mu \mathrm{g} / \mathrm{L})\end{array}$ & $\begin{array}{l}\text { Vanadium } \\
(\mu \mathrm{g} / \mathrm{L})\end{array}$ & $\begin{array}{c}\text { Zinc } \\
(\mu \mathrm{g} / \mathrm{L})\end{array}$ & \\
\hline 130 & 14 & $<0.1$ & $<10$ & 5 & $<1$ & $<1.0$ & 81 & $<6$ & 7 & \\
\hline
\end{tabular}

${ }^{1}$ Isotopic analyses by Desert Research Institute, written communication, 1988.

\section{Relation to Regional Water Chemistry}

Water from PM-3 does not fit into the sodium potassium bicarbonate facies of other Pahute Mesa waters as defined by Winograd and Thordarson (1975) because calcium, chloride, and sulfate concentrations are higher in the PM-3 water (fig. 16; Blankennagel and Weir, 1973, table 10). An exception is water from well UE-20j. Well UE-20j is about 1 mi north of PM-3 and also is west of an inferred hydraulic boundary. The chemistry of water at this site is similar to that of PM-3. The differences in concentration between water west of the caldera and water within the Silent Canyon caldera indicate that water from west of the hydraulic boundary represents a different ground-water source than water east of it.

Magnesium, bicarbonate, and fluoride concentrations in the PM-3 water are in the range of concentrations from Yucca Mountain area waters, but calcium, sodium, potassium, chloride, and sulfate concentrations exceed those of water from Yucca Mountain (Benson and others, 1983, table 1). These differences suggest PM-3 water may not flow toward the Yucca Mountain area. Major ion concentrations in PM-3 water are similar to Oasis Valley water, except sulfate, which is higher at PM-3 (Malmberg and Eakin, 1962, table 3). These similarities in chemistry, and a southsloping gradient suggest that PM-3 water may flow toward the Oasis Valley discharge area.

\section{SUMMARY}

PM-3, a 3,019-ft test well, was drilled to collect ground-water data on Pahute Mesa between the Nevada Test Site and Oasis Valley discharge area. The test well was rotary drilled from September 1 to 19 , 1988, with air-foam using conventional circulation. The test well was cased with 10.75-in. diameter casing to a depth of $1,473 \mathrm{ft}$. A 9.875-in. diameter hole was drilled below the casing to $3,019 \mathrm{ft}$.

Volcanic rocks of Tertiary age were penetrated the entire depth of the test well. Lithologic samples, drill-bit cuttings, and sidewall cores were collected and are stored in the USGS core library at Mercury, Nev. Core samples and geophysical logs helped determine the test-well lithology and hydrostratigraphy. Geophysical logs indicate that the tuffs are fractured in places, and that some of the fractures control the hydrologic response of the well. A moderately welded ashflow tuff, the Tiva Canyon Tuff of the Paintbrush Group was the most conductive unit penetrated by the test well. Effective porosity ranged from 19 to 38 percent in the tuffs and rhyolites, and was 4 percent in basalt. Total porosity ranged from 33 to 55 percent in the tuffs and from 12 to 27 percent in basalt and 12 to 46 percent in rhyolite. The $1.00^{\circ} \mathrm{C} / 100 \mathrm{ft}$ temperature gradient was high compared with that in other Pahute 


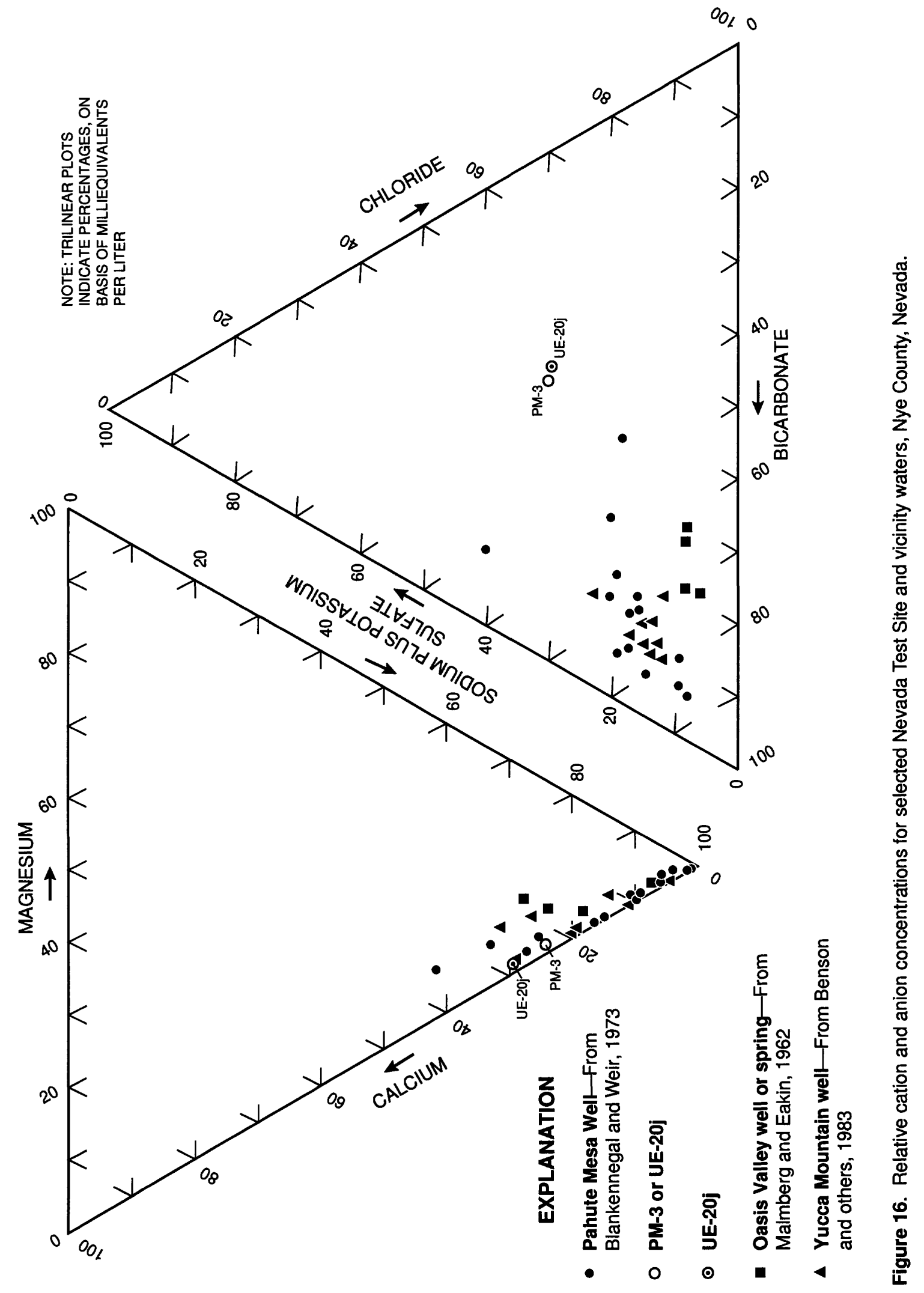


Mesa wells, possibly resulting from a buried heat source, which may be the southward extension of a granitic body north of PM-3.

Six injection tests were made on the packed intervals of the well. The time-hydraulic head data were matched to type curves for radial-confined flow. The tests indicate transmissivities range from $3.1 \times 10^{-3}$ to $25 \mathrm{ft}^{2} / \mathrm{d}$. The sum of transmissivities is $28 \mathrm{ft} / \mathrm{d}$. Estimates of hydraulic conductivity range from $6.0 \times 10^{-5}$ to $0.12 \mathrm{ft} / \mathrm{d}$. The geometric mean of hydraulic conductivity is $1.7 \times 10^{-3} \mathrm{ft} / \mathrm{d}$. The storage coefficient was estimated to be between $2.1 \times 10^{-5}$ and $3.8 \times 10^{-3}$, which is typical of a confined aquifer. Estimates of specific storage ranged from $\left(1.1 \times 10^{-7}\right) / \mathrm{ft}$ to $\left(7.2 \times 10^{-5}\right) / \mathrm{ft}$ and averaged $\left(6.8 \times 10^{-6}\right) / \mathrm{ft}$.

An aquifer test was run for 31 hours with an average pump discharge of $169 \mathrm{gal} / \mathrm{min}$ and a maximum water-level drawdown of $78 \mathrm{ft}$. Well-bore storage affected test results for the first hour of pumping. Timedrawdown data were matched to radial-flow type curves for unconfined and confined conditions. Assuming unconfined conditions, estimates of transmissivity ranged from 38 to $70 \mathrm{ft}^{2} / \mathrm{d}$ and hydraulic conductivity ranged from $3.4 \times 10^{-2}$ to $6.2 \times 10^{-2} \mathrm{ft} / \mathrm{d}$. Estimates of storage determined from the injection tests, however, show that even the uppermost interval of the well responds as if it were confined. Assuming confined conditions, with well-bore storage taken into account, transmissivity estimates ranged from 360 to $840 \mathrm{ft}^{2} / \mathrm{d}$. Hydraulic conductivity estimates ranged from 0.32 to $0.74 \mathrm{ft} / \mathrm{d}$.

The response of the unconfined part of the aquifer cannot explicitly be separated from the response of the confined part of the aquifer. However, the most transmissive section of the aquifer, interval $D$, probably was the major control of drawdown during the pumping test; interval D remained confined throughout the test. On the basis of this assumption, the best estimate of transmissivity from leaky confined theory is $360 \mathrm{ft}^{2} / \mathrm{d}$ for the interval from 1,473 to $2,605 \mathrm{ft}$ under the conditions of this test and the best estimate of hydraulic conductivity is $0.32 \mathrm{ft} / \mathrm{d}$.

Water-level altitude fluctuated from 4,362 to $4,368 \mathrm{ft}$, in the test well during October 1988 to June 1990.

Analyses of formation water sampled during pumping indicate that the PM-3 water is a sodium mixed-anion water. Sodium is the predominant cation and bicarbonate, sulfate, and chloride are the major anions. The calcium, chloride, and sulfate concentra- tions are high compared to other Pahute Mesa waters, except for water from a nearby well, UE-20j. The water chemistry indicates that flow may be to the south, toward Oasis Valley.

\section{REFERENCES CITED}

Benson, L.V., Robison, J.H., Blankennagel, R.K., and Ogard, A.E., 1983, Chemical composition of ground water and the locations of permeable zones in the Yucca Mountain area, Nevada: U.S. Geological Survey OpenFile Report 83-854, 19 p.

Blankennagel, R.K., and Weir, J.E., Jr., 1973, Geohydrology of the eastern part of Pahute Mesa, Nevada Test Site, Nye County, Nevada: U.S. Geological Survey Professional Paper 712-B, $35 \mathrm{p}$.

Boulton, N.S., 1963, Analysis of data from non-equilibrium pumping tests allowing for delayed yield from storage: London, Institute of Civil Engineers Proceedings, v. 26, p. $469-482$.

Byers, F.M., Jr., Carr, W.J., Christiansen, R.L., Lipman, P.W., Orkild, P.P., and Quinlivan, W.D., 1976a, Geologic map of the Timber Mountain caldera area, Nye County, Nevada: U.S. Geological Survey Miscellaneous Investigations Series Map I-891.

Byers, F.M., Jr., Carr, W.J., Orkild, P.P., Quinlivan, W.D., and Sargent, K.A., 1976b, Volcanic suites and related caldrons of Timber Mountain-Oasis Valley caldera complex, southern Nevada: U.S. Geological Survey Professional Paper 919, $70 \mathrm{p}$.

Claassen, H.C., 1985, Sources and mechanisms of recharge for ground water in the west-central Amargosa Desert, Nevada - A geochemical interpretation: U.S. Geological Survey Professional Paper 712-F, 31 p.

Cooper, H.H., Jr., and Jacob, C.E., 1946, A generalized graphical method for evaluating formation constants and summarizing well-field history: American Geophysical Union Transactions, v. 27, no. 4, p. 526-534.

Cooper, H.H., Jr., Bredehoeft, J.D., and Papadopulos, I.S., 1967, Response of a finite diameter well to an instantaneous charge of water: Water Resources Research, v. 3, no. 1, p. 263-269.

de Marsily, Ghislain, 1986, Quantitative hydrogeologyGroundwater hydrology for engineers: New York, Academic Press, Inc., $440 \mathrm{p}$.

Dresser Atlas, 1982, Interpretive methods for production well logs: Houston, Dresser Industries, Inc., 159 p.

Freeze, R.A., and Cherry, J.A., 1979, Groundwater: Englewood Cliffs, N.J., Prentice-Hall, Inc., 604 p.

Hantush, M.S., and Jacob, C.E., 1955, Nonsteady radial flow in an infinite leaky aquifer: American Geophysical Union Transactions, v. 36, no. 1, p. 95-100. 
Healey, D.L., 1968, Application of gravity data to geologic problems at Nevada Test Site, in Eckel, E.B., ed., Nevada Test Site: Geologic Society of America Memoir 110, p. 147-156.

Healey, D.L., Harris, R.N., Ponce, D.A., and Oliver, H.W., 1987, Complete Bouguer gravity map of the Nevada Test Site and vicinity, Nevada: U.S. Geological Survey Open-File Report 87-506.

Keys, W.S., and MacCary, L.M., 1971, Application of borehole geophysics to water-resources investigations: U.S. Geological Survey Techniques of Water-Resources Investigations, book 2, chap. E1, $126 \mathrm{p}$.

Lohman, S.W., 1972, Ground-water hydraulics: U.S. Geological Survey Professional Paper 708, 70 p.

Malmberg, G.T., and Eakin, T.E., 1962, Ground-water appraisal of Sarcobatus Flat and Oasis Valley, Nye and Esmeralda Counties, Nevada: Nevada Department of Conservation and Natural Resources, Ground-water Resources-Reconnaissance Series Report 10, 39 p.

-1964, Relation of fluoride content to recharge and movement of ground water in Oasis Valley, southern Nevada: U.S. Geological Survey Professional Paper 475-D, p. 189-191.

Neuman, S.P., 1975, Analysis of pumping test data from anisotropic unconfined aquifers considering delayed gravity response: Water Resources Research, v. 11, no. 2, p. 329-342.

O'Connor, J.T., Anderson, R.E., and Lipman, P.W., 1966, Geologic map of the Thirsty Canyon quadrangle, Nye County, Nevada: U.S. Geologic Survey Geologic Quadrangle Map GQ-524, scale 1:24,000.

Orkild, P.P., Sargent, K.A., and Snyder, R.P., 1969, Geologic map of Pahute Mesa, Nevada Test Site and vicinity, Nye County, Nevada: U.S. Geologic Survey Miscellaneous Geologic Investigations Map I-567.
Papadopulos, I.S., and Cooper, H.H., Jr., 1967, Drawdown in a well of large diameter: Water Resources Research, v. 3, no. 1, p. 241-244.

Robison, J.H., Stephens, D.M., Luckey, R.R., and Baldwin, D.A., 1988, Water levels in periodically measured wells in the Yucca Mountain area, Nevada, 1981-87: U.S. Geological Survey Open-File Report 88-468, 132 p.

Rush, F.E., 1968, Index of hydrographic areas Nevada: Nevada Division of Water Resources, Information Report 6, 38 p.

Sawyer, D.A., Fleck, R.J., Lanphere, M.A., Warren, R.G., Broxton, D.E., and Hudson, M.R., 1994, Episodic caldera volcanism in the Miocene southwestern Nevada volcanic field—Revised stratigraphic framework, ${ }^{40} \mathrm{Ar} /{ }^{39} \mathrm{Ar}$ geochronology, and implications for magmatism and extension: Geological Society of America Bulletin, v. 106, p. 1304-1318

Todd, D.K., 1976, Ground-water hydrology (2d edition): New York, John-Wiley, 535 p.

Waddell, R.K., Robison, J.H., and Blankennagel, R.K., 1984, Hydrology of Yucca Mountain and vicinity, Nevada-California - Investigative results through mid-1983: U.S. Geological Survey Water-Resources Investigations Report 84-4267, 72 p.

White, A.F., 1979, Geochemistry of ground water associated with tuffaceous rocks, Oasis Valley, Nevada: U.S. Geological Survey Professional Paper 712-E, 25 p.

Winograd, I.J., and Thordarson, William, 1975, Hydrogeologic and hydrochemical framework, south-central Great Basin, Nevada-California, with special reference to the Nevada Test Site: U.S. Geological Survey Professional Paper 712-C, $126 \mathrm{p}$.

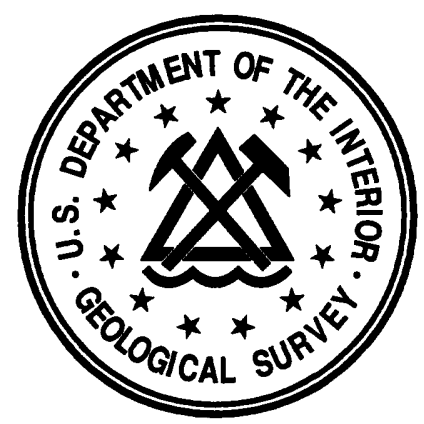

